AUTARQUIA ASSOCIADA À UNIVERSIDADE DE SÃO PAULO

O COMPROMETIMENTO COMO ESTRATÉGIA PARA A ADOÇÃO DE UM SISTEMA DE GESTÃO AMBIENTAL: O CASO DE UMA INSTITUIÇÃO PÚBLICA DE PESQUISA

MARIA CECÍLIA CAVALCANTE DA SILVA

Tese apresentada como parte dos requisitos para obtenção do Grau de Doutor em Ciências na Área de Tecnologia Nuclear - Reatores

Orientador:

Prof. Dr. Delvonei Alves de Andrade 
INSTITUTO DE PESQUISAS ENERGÉTICAS E NUCLEARES

Autarquia associada à Universidade de São Paulo

\title{
O COMPROMETIMENTO COMO ESTRATÉGIA PARA A ADOÇÃO DE UM SISTEMA DE GESTÃO AMBIENTAL: O CASO DE UMA \\ INSTITUIÇÃO PÚBLICA DE PESQUISA
}

\author{
MARIA CECÍLIA CAVALCANTE DA SILVA
}

Tese apresentada como parte dos requisitos para obtenção do Grau de Doutor em Ciências na Área de Tecnologia Nuclear - Reatores

Orientador:

Prof. Dr. Delvonei Alves de Andrade

Versão Corrigida

Versão Original disponível no IPEN

São Paulo

2017 


\section{AGRADECIMENTOS}

Ao Instituto de Pesquisas Energéticas e Nucleares - IPEN, pela oportunidade para realização deste curso de doutorado.

Aos servidores e funcionários contratados, lotados no Setor de Pós-Graduação do IPEN, pela paciência e orientação quanto aos tramites administrativos concernentes ao curso.

Ao Prof. Dr. Delvonei Alves de Andrade, meu Orientador, pela persistência, apoio e boa vontade em estar sempre presente durante toda a elaboração deste trabalho.

As Doutoras Alessandra Quishida, Martha Marques F. Vieira e Sandra Harumi Fukurozaki, por terem aceito participar da Comissão Julgadora desta Tese, contribuindo com seus conhecimentos de forma muito efetiva. Do mesmo modo ao Dr. José Octávio Armani Paschoal.

Ao meu companheiro Edson Franco Lima, sempre presente e disposto a prestar seu apoio. Obrigado pelas discussões, pelo tempo gasto, que refletem o valor de uma amizade, que o tempo não apaga.

Ao meu filho Tiago Cavalcante Silva, por entender as minhas ausências nas reuniões em família neste período de estudo, junto com minha netinha e nora.

E à Deus, Senhor de minha vida. 


\section{RESUMO}

Esta tese, utilizando-se do mapa cognitivo Strategic Options Development and Analysis - SODA, se propôs a atender o objetivo nela especificado, ou seja, avaliar a importância do comprometimento organizacional para a implementação de um Sistema de Gestão Ambiental - SGA por parte dos quinze Gerentes de uma Instituição Pública Federal, localizada no estado de São Paulo. Os dados que compuserem o mapa cognitivo, foram obtidos por meio de entrevista face a face, no período de maio a novembro de 2015, e de reuniões grupais com os referidos Gerentes, no período de dezembro de 2015 a março de 2016. A utilização do método de estruturação de problemas - Problem Structuring Methods (PSMs) - mapa cognitivo - SODA possibilitou investigar, as possíveis incertezas, complexidades e conflitos, voltados para o elemento comprometimento, provenientes da adoção de uma gestão ambiental, por intermédio da implementação de um Sistema de Gestão Ambiental - SGA. O resultado da análise do mapa cognitivo demonstrou a importância do comprometimento organizacional quando da intenção de se adotar um Sistema de Gestão Ambiental. Diferentemente do entendimento de Barbieri (2007), o presente estudo coloca a importância desse comportamento não somente por parte da alta direção, mas também por parte de toda a equipe a ser envolvida nas atividades concernentes a tal sistema. Permitiu também a construção de um modelo de mensuração do comprometimento em relação ao Sistema de Gestão Ambiental - SGA. O comprometimento mensurado por meio de referido instrumento, está dividido em dois componentes: afetivo que tem o comprometimento como um apego, como um envolvimento, onde ocorre a identificação com a empresa, funcionários com forte comprometimento afetivo permanecem na empresa porque querem, e normativo o comprometimento como uma obrigação em permanecer na organização, funcionários identificados com esse comportamento permanecem na empresa porque sentem que tem essa obrigação. O modelo de mensuração do comprometimento neste estudo sugerido, a ser validado em estudos longitudinais, permitirá mapear elementos de forma que possam observar tendências. Referido instrumento não foi validado neste estudo, no entanto sugere-se que estudos futuros, por meio de estudos longitudinais ${ }^{1}$ procedam sua validação.

Palavras Chave: sistema de gestão ambiental; comprometimento organizacional; mapas cognitivos SODA.

\footnotetext{
${ }^{1}$ Estudos longitudinais usam uma amostra para descrever elementos administrativos. Em vez de descrevê-los em um único ponto no tempo, os dados longitudinais descrevem eventos ao longo do tempo. Os dados longitudinais permitem mapear elementos administrativos de modelo que possam observar as tendências. (Hair et al, 2005, p. 88).
} 


\begin{abstract}
This thesis, using the Cognitive Map Strategic Options Development and Analysis (SODA), is proposed to meet the objective specified therein, i.e. to evaluate the importance of the organizational commitment to the implementation of an Environmental Management System (SGA), by the fifteen Managers of a Federal Public Institution, located in the state of São Paulo. The data composing the cognitive map were obtained through a face-to-face interview, from May to November 2015, and group meetings with the aforementioned managers from December 2015 to March 2016. The use of the Problem Structuring Methods (PSMs) - SODA cognitive map made it feasible to investigate possible uncertainties, complexities and conflicts, related to the commitment element, from the adoption of the environmental management through the implementation of An Environmental Management System - EMS. The results of the cognitive map analysis showed the importance of the organizational commitment, when an Environmental Management System is intended to be adopted. Differently from Barbieri's (2007) understanding, the present study places the importance of this behavior, not only by the top management, but also by the whole team to be involved in the activities related to such a system. It, also, allowed the construction of a commitment measurement model in relation to the Environmental Management System - EMS. The commitment measured by this instrument is divided into two components: affective, which has the commitment as an attachment and, even, involvement, where the identification with the company occurs: employees with strong affective commitment remain in the company because they want it and, also, as normative involvement. The commitment is felt as an obligation to remain in the organization: employees identified with this behavior remain in the company because they feel they should do it. The model of commitment measurement in this suggested survey, to be validated in longitudinal studies, will allow elements to be mapped so that trends may be observed. The mentioned instrument was not validated in this study, however, it is suggested that future research, through longitudinal studies ${ }^{2}$, would do it.
\end{abstract}

Keywords: environmental management system; organizational commitment; SODA cognitive maps.

\footnotetext{
${ }^{2}$ Longitudinal studies use a sample to describe administrative elements. Instead of describing them at a single point in time, longitudinal data describe events continually. Longitudinal data allow model administrative elements, which may observe trends, to be mapped. (Hair et al., 2005, p.88)
} 


\section{Sumário}

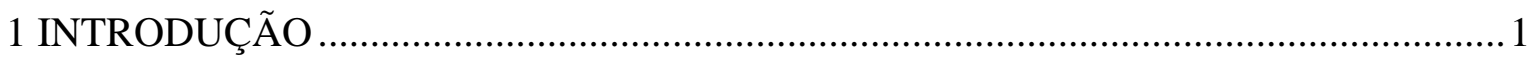

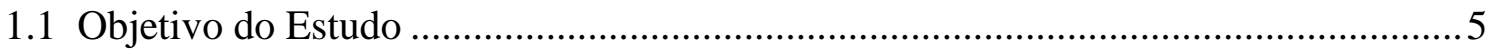

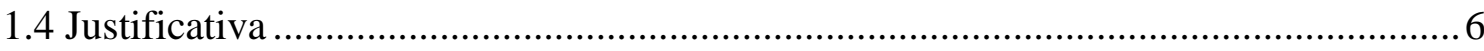

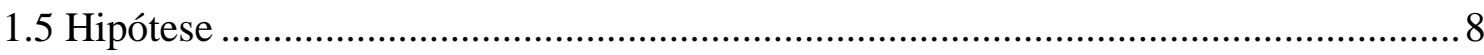

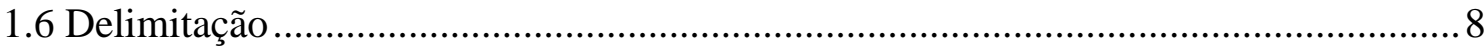

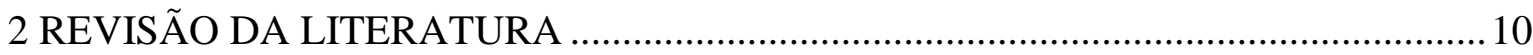

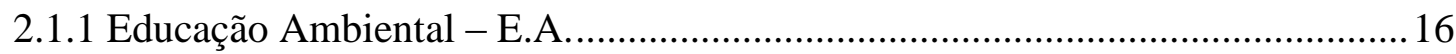

2.1.2 Responsabilidade Social Empresarial ............................................................. 18

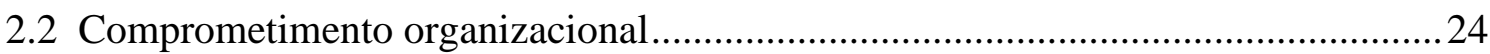

2.2.1 Noções conceituas do comprometimento organizacional................................25

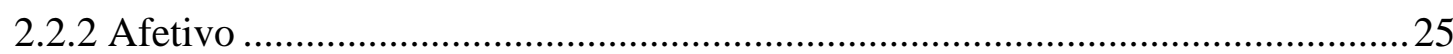

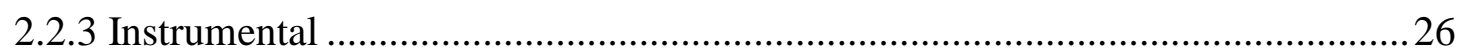

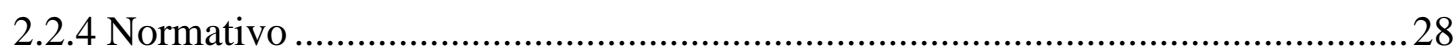

2.3 Análise e desenvolvimento de opções estratégicas..............................................29

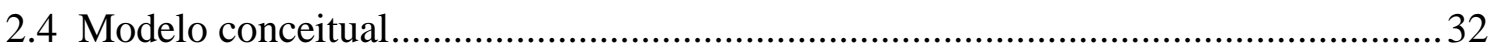

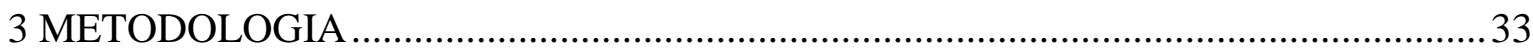

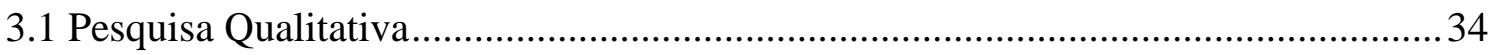

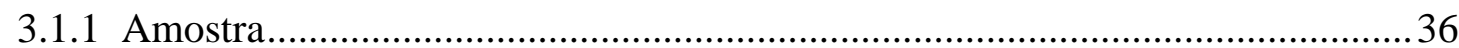

3.1.2 Coleta dos Dados e Instrumento de Medida ver redação verde.......................... 37

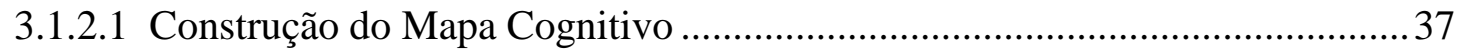

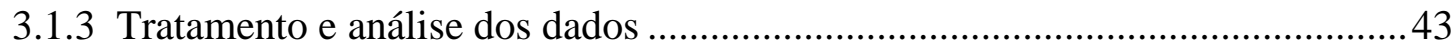


3.1.4 Limitação do Método 52

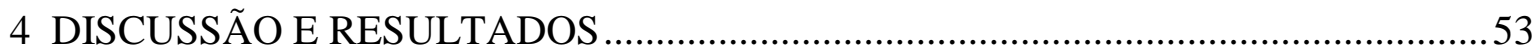

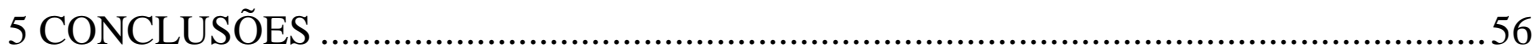

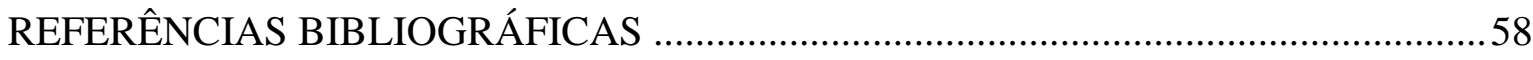

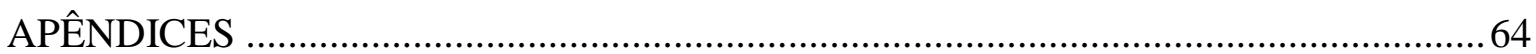

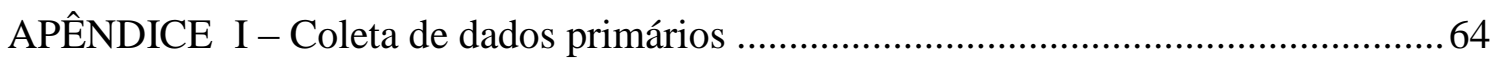

APÊNDICE II - Mapa cognitivo final sem interação grupal ........................................66

APÊNDICE III - Mapa cognitivo final com interação grupal .....................................6 67

APÊNDICE IV - Modelo de mensuração do comprometimento em relação a adoção de

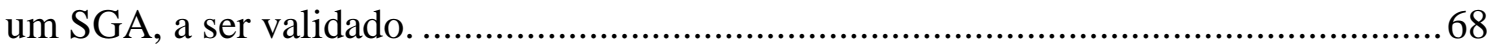

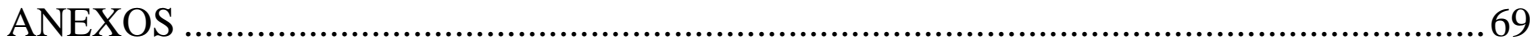

ANEXO - I - Processo - Strategic Options Development and Analysis - SODA........69

ANEXO - II - Strategic Options Development and Analysis - SODA - utilizada no presente estudo 


\section{LISTA DE FIGURAS}

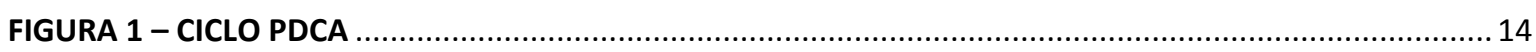

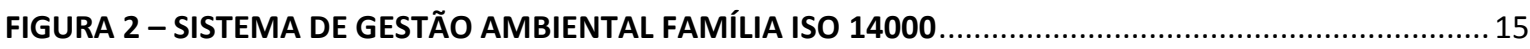

FIGURA 3 - ELEMENTOS DE UM SGA - CÂMARA DE COMÉRCIO INTERNACIONAL ................................. 16

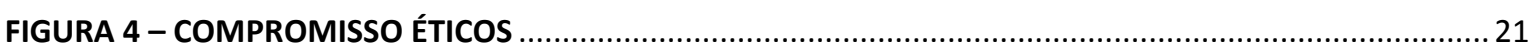

FIGURA 5 - ENRAIZAMENTO NA CULTURA ORGANIZACIONAL ....................................................... 21

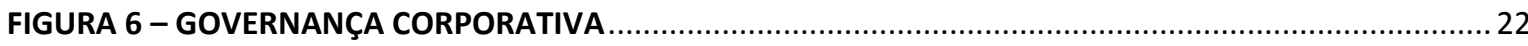

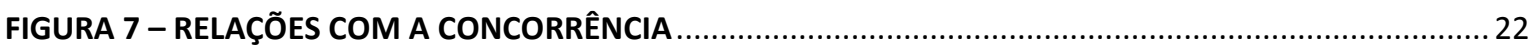

FIGURA 8 - DIÁLOGO E ENGAJAMENTO DAS PARTES INTERESSADAS .................................................. 23

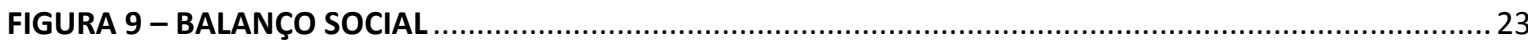

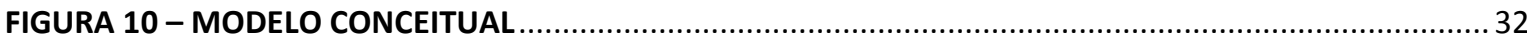

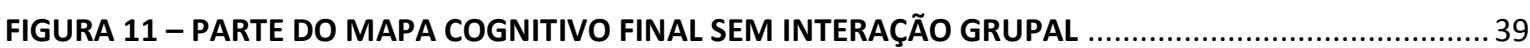

FIGURA 12 - MAPA COGNITIVO FINAL COM INTERAÇÃO GRUPAL EXPRESSO EM GRAFOS DIRECIONADOS

FIGURA 13 - IDENTIFICAÇÃO DO CONSTRUTO TAIL NO MAPA COGNITIVO FINAL COM INTERAÇÃO GRUPAL

FIGURA 14 - IDENTIFICAÇÃO DO CONSTRUTO HEAD NO MAPA COGNITIVO FINAL COM INTERAÇÃO

GRUPAL

FIGURA 15 - IDENTIFICAÇÃO DAS STRATEGIC OPTIONS DO MAPA COGNITIVO FINAL COM INTERAÇÃO GRUPAL 


\section{LISTA DE QUADROS}

QUADRO 1 - PARTE DOS CONSTRUTOS DO MAPA COGNITIVO SEM INTERAÇÃO GRUPAL, E INFLUÊNCIAS

QUADRO 2 - CONSTRUTOS IDENTIFICADOS NO MAPA DE INTERAÇÃO GRUPAL.

QUADRO 3 - DESCRIÇÃO DOS CONSTRUTOS QUE INCIDEM DO CONSTRUTO 15, CARACTERIZADO NESTE

ESTUDO COMO “TAIL" .46

QUADRO 4 - DESCRIÇÃO DO CONSTRUTO HEAD DO MAPA COGNITIVO COM INTERAÇÃO GRUPAL .49

QUADRO 5 - CONSTRUTOS QUE INCIDEM SOBRE O CONSTRUTO STRATEGIC OPTION E CONSTRUTOS QUE PARTEM DESSE CONSTRUTO 50 
LISTA DE TABELAS

TABELA 1 - IMPLOSIONS / EXPLOSIONS. 


\section{INTRODUÇÃO}

Percebidos como uma crise de dimensão planetária desde a década de 60, os desafios ambientais e sociais estão levando as organizações a estabelecer-se em um quadro cujo diferencial é "deixar-se ver". Atividades administrativas e operacionais voltadas para a eliminação dos problemas ambientais causados por sua atuação ou para evitar sua ocorrência no futuro, compõem referido diferencial.

As organizações quando da realização de seus processos produtivos, e dentro de oportunidades significativas para alterar a natureza, foram ao longo dos anos utilizando-se de mecanismos que contribuíram para a contaminação do ar, da terra, dos rios e dos mares. Ignorando dessa forma um alerta por demais assustador para ser desprezado, como destacado por Jacobi (2005) ao se referir a obra de Carson (1962) - Primavera Silenciosa. Diz ele: ... pela primeira vez, a necessidade de regulamentar a produção industrial de modo a proteger o meio ambiente se tornou aceita.

Referida utilização sem medidas resultou na atual necessidade de ações, por parte dessas organizações, no sentido de corrigir os efeitos maléficos resultantes, cuja consequência é extremante prejudicial ao seu próprio desenvolvimento.

Hoje, adotar procedimentos que favoreça a preservação do ambiente, bem como utilizar-se dos recursos naturais de forma sustentável, é imperativo no processo produtivo dessas organizações. A obediência as leis ambientais que restringem a emissão de poluentes, a disposição de resíduos, a emissão de ruídos e a exploração de recursos naturais são conjunturas globais que as organizações obrigatoriamente estão tendo que considerar em todas as suas ações empresariais.

A adoção de práticas, cujo objetivo é reduzir ao máximo o impacto ambiental das atividades econômicas, pode ser facilitada por meio de ações simples, como por exemplo, a reutilização de materiais que outrora seriam descartados, refletindo na economia da matéria prima, água e energia. Estas ações são bem vistas pela sociedade, o que resulta em uma imagem melhor no mercado e melhores relações comerciais refletindo-se por exemplo, em linhas de crédito para financiamento de projetos voltados as atividades que favoreçam o meio ambiente.

Neste sentido procura o presente estudo investigar maneiras que favoreçam uma gestão ambiental, levando-se em conta os temas a ela relacionados.

Concernente a referidos temas está a existência de um mercado em crescente processo de conscientização ecológica, no qual, segundo Nicolella et al. (2004), mecanismos 
como selos verdes e Normas, como a Série ISO 14000, passam a constituir atributos desejáveis, não somente para a aceitação e compra de produtos e serviços, como também para a construção de uma imagem ambientalmente positiva junto à sociedade.

Nessa linha de raciocínio observa-se também, que para obter melhores resultados com menos recursos, em decorrência de ações planejadas e coordenadas, diversas organizações veem adotando um conjunto de atividades administrativas e operacionais interrelacionadas para abordar os problemas ambientais atuais ou para evitar seu surgimento. Esse conjunto de atividades é denominado por Barbieri, 2007 como Sistema de Gestão Ambiental - SGA.

Concernente ao SGA, cita Nicolella et al.,2004:

\begin{abstract}
"As ações de empresas em termos de preservação, conservação ambiental e competitividade estratégica - produtos, serviços, imagem institucional e de responsabilidade social - passaram a consubstanciar-se na implantação de sistemas de gestão ambiental para obter reconhecimento da qualidade ambiental de seus processos, produtos e condutas obtidos por meio de certificação voluntária, com base em normas internacionalmente reconhecidas". (Nicolella et al., 2004, p.8)
\end{abstract}

Relacionado ao Sistema de Gestão Ambiental - SGA está como um dos destaques o comprometimento, que como bem coloca Barbieri (2007), ocupa o primeiro lugar com sua efetivação por parte dos dirigentes da organização.

Em relação ao comprometimento mencionado por Barbieri (2007), comportamento analisado neste estudo como comprometimento organizacional, faz-se necessário mencionar que referido comportamento seja nos enfoques: afetivo ${ }^{3}$, instrumental ${ }^{4}$ ou normativo ${ }^{5}$, possui o poder de enfrentar as mudanças necessárias que exigem não somente a conscientização sobre sua importância, mas também, a vontade dos indivíduos envolvidos, em comprometer-se com os novos objetivos a serem propostos pela organização (Horn \& Cerutti, 2013; Costa, 2014; Paiva et al., 2015)

Considerado como um "diferencial", o comprometimento organizacional vem desde a década de 70 sendo foco de interesse tanto por estudiosos (Porter \& Steers, 1973; Hrebiniak \& Alluto, 1972; Buchanan, 1974; Mowday et al, 1979, entre outros), como por empresários que buscam manter sua força de trabalho com graus elevados desse elemento. E o presente estudo procura caracteriza-lo como uma "estratégia" quando da adoção de um SGA.

\footnotetext{
${ }^{3}$ Comprometimento visto como o resultado de um vínculo afetivo em relação à organização. (Meyer e Allen, 1997)

${ }^{4}$ Comprometimento como resultante de um vínculo que decorre dos custos associados em deixar a organização. (Meyer e Allen, 1997)

${ }^{5}$ Comprometimento visto como uma obrigação em permanecer na organização. (Meyer e Allen, 1997)
} 
Estratégia no sentido abordado pela característica da gestão estratégica de pessoas que considera a relevância da totalidade dos indivíduos nas organizações e não somente os altos executivos, ou o pessoal operacional. (Silveira \& Miranda, 2011).

Preceder uma investigação do comprometimento organizacional em relação a adoção de um Sistema de Gestão Ambiental, proporcionará o conhecimento antecipado do comportamento dos atores a serem envolvidos no novo tipo de gestão, propiciando o desenvolvimento das atividades administrativas e operacionais inter-relacionadas, por pessoas comprometidas, quando da abordagem dos problemas ambientais atuais ou na prevenção de seu surgimento.

A referida investigação é também relevante no decorrer do desenvolvimento dessas atividades, visto o diferencial de tal comportamento. Manter a força de trabalho com grau elevado de comprometimento proporciona a manutenção de uma gestão eficaz.

A esse respeito procura esta pesquisa, em um primeiro momento, examinar por meio do mapa cognitivo Strategic Options Development and Analysis - SODA, possíveis incertezas, complexidades e conflitos, voltados para o elemento comprometimento, quando da adoção de uma gestão ambiental por intermédio da implementação de um SGA, por parte de quinze Gerentes da Instituição investigada, um Instituto Federal de Pesquisas, localizado na cidade de São Paulo.

Segundo Mingers \& Rosenhead, (2004 apud Morita, 2013), o mapa cognitivo SODA proposto por Eden \& Sims, 1981 é um dos métodos que satisfazem as quatro exigências de um instrumento por eles definidos como Problem Structuring Methods (PSMs); a saber:

$1^{\circ}$ Ativar várias perspectivas alternativas para serem interpostas em associação entre elas;

$2^{o}$ Ser cognitivamente acessiveis aos agentes, com uma variedade de experiências e sem treinamento especializado, a fim que a representação desenvolvida, possa informar o processo participativo da estruturação do problema;

$3^{\circ}$ Agir interativamente de modo que a representação do problema se ajuste para refletir o estado e a fase da discussão entre os agentes.

$4^{\circ}$ Permitir melhorias parciais ou locais a serem identificadas $e$ comprometidas, ao invés de exigir uma solução global, o que implicaria em uma fusão de interesses variados. (Rosenhead \& Mingers 2004 apud Morita, 2013)

Conforme Rosenhead, 1996 apud Curo et al, 2012) a prática essencial dos métodos de estruturação de problemas é organizado de forma a permitir a exploração de 
soluções, com o intuito de ajudar os envolvidos a elaborar planos igualmente estruturados para futuras ações.

Os métodos de estruturação de problemas ou Problem Structuring Methods (PSMs), como tratado por Curo et al, 2012, não se baseiam em métodos quantitativos e não se representa matematicamente, porém sua tarefa mais exigente em um processo situacional de decisão é definir qual é o problema. (Curo et al 2012).

A este respeito afirmam Georgiou \& Stevaux:

"PSMs constroem um mapa de situações problemáticas e, com a ajuda desse mapa são identificados os problemas individuais e suas inter-relações; ou seja, se existe um sistema de problemas é fortemente recomendável encontrar uma solução sistêmica." (Georgiou \& Stevaux, 2008, apud Curo et al, 2012, p. 4).

Tendo em vista que a implementação de um SGA implica na integração do maior número de partes interessadas para tratar as questões ambientais, (Barbieri, 2007), envolvendo os elementos: estabelecimento da política ambiental; avaliação dos impactos ambientais atuais e futuros; planos de fixação de objetivos e metas; instrumentos de acompanhamento e avaliação das ações planejadas e do próprio desempenho desse sistema como um todo; além do relevante elemento comprometimento, as organizações procuram por alternativas que lhes propicie condições favoráveis para alcançar resultados satisfatórios e eficazes quanto a essa adoção.

Com tal meta, a Instituição aqui pesquisada, bem como, as demais organizações buscam constantemente manter sua força de trabalho comprometida, dada a importância desse comportamento quando do estabelecimento de uma gestão diferenciada, no caso desse estudo, a Gestão Ambiental, que estabelece a obrigação de considerar o meio ambiente nas decisões e adoções das concepções administrativas e tecnológicas que irão também contribuir para ampliar a capacidade de suporte do planeta. (Barbieri, 2007).

A necessidade de referido comportamento desperta curiosidade em relação ao elemento comprometimento, visto que quando da investigação de tal comportamento, identifica-se o poder de enfrentar mudanças necessárias que exigem não somente a conscientização sobre sua importância, mas também, a vontade dos indivíduos envolvidos, em comprometer-se com os novos objetivos a serem propostos pela organização.

Concernente a importância do comprometimento segue exemplificado nesta tese, manifestação do Tribunal de Contas da União datada do ano 2015. Referida manifestação adverte uma Fundação Federal que utiliza recursos da União, a doravante conciliar suas 
solicitações de dotações orçamentárias com a sua efetiva capacidade Técnica, operacional e administrativa quando da utilização de referidos recursos.

De fato, os projetos meritórios e de grande alcance social pretendidos pela alta administração dessa Fundação, não considerou investigar o comprometimento dos servidores envolvidos nas lides administrativas para ultimar os procedimentos necessários a sua formalização.

Como resultado os recursos disponibilizados pela União não foram utilizados gerando como prejuízo maior o não usufruto dos benefícios oriundos desses projetos pela população alvo.

Neste sentido pergunta-se a) como é tratado o elemento comprometimento ${ }^{6}$ quando da intenção de adotar um Sistema de Gestão Ambiental em uma Instituição Pública Federal de Pesquisa e, b) de que forma este comportamento se caracterizará como estratégia ${ }^{7}$ para a adoção de um SGA? Referida questão evidencia-se também pela necessidade da adoção desse tipo de gestão devidamente estruturada, para com ela oferecer resultados eficazes e congruentes com os objetivos da empresa.

\subsection{Objetivo do Estudo}

Objetivo Geral - avaliar a importância do comprometimento organizacional para a implementação de um Sistema de Gestão Ambiental - SGA por parte de quinze Gerentes de uma Instituição Pública Federal de Pesquisa e elaborar um modelo de mensuração desse comportamento.

Concernente a adoção de um SGA encontra-se o entendimento de Dias (2011) quanto a importância de referido sistema integrado numa perspectiva mais ampla que envolva sempre a mudança da cultura organizacional da empresa, introduzindo o componente ambiental entre as preocupações de seu corpo de funcionários.

Faz-se necessário mencionar também que um SGA integrado que envolva o universo cultural da organização, considera a verificação do padrão de procedimento e o processo de socialização de seus membros; as respostas a incidentes críticos da história da organização; as crenças, valores e convicções dos criadores ou portadores da cultura.

\footnotetext{
${ }^{6}$ Comprometimento visto como o nível do vínculo psicológico de um indivíduo com a organização, onde esse vínculo tem implicação na resolução do empregado em permanecer na empresa e cuja descrição da natureza do estado psicológico foi tida como: afetiva; instrumental e normativa (Meyer \& Allen, 1991)

${ }^{7}$ No sentido abordado por uma das seis características da gestão estratégica de pessoas apontadas por Silveira \& Miranda (2011).
} 
Referida colocação contemplada por Schein (2009) em seu modelo teórico que propõe a definição de cultura organizacional, como segue:

Cultura organizacional é um conjunto de pressupostos básicos que um grupo inventou, descobriu ou desenvolveu ao aprender como lidar com os problemas de adaptação externa e integração interna e que funcionaram bem o suficiente para serem considerados válidos e ensinados a novos membros como a forma correta de perceber, pensar e sentir, em relação a esses problemas. (SHEIN, 2009, p. 120).

Objetivo Específico:

a. examinar por meio do método de estruturação de problemas - Problem Structuring Methods (PSMs) - Mapas SODA ${ }^{8}$ as possíveis incertezas, complexidades e conflitos decorrentes de referida avaliação. ;

b. descrever, explicitar e conhecer a "situação problemática investigada" e com essas inferências estruturar um modelo de mensuração do comprometimento, com proposta de ser validado.

c. estabelecer, com a estruturação do modelo de mensuração do comprometimento a ser proposto, referido comportamento como uma estratégia para a adoção de um SGA. Estratégia como um caminho que considera a relevância da totalidade dos indivíduos nas organizações e não apenas determinados grupos.

\subsection{Justificativa}

Se a implementação bem sucedida de um Sistema de Gestão Ambiental é importante para as organizações, visto a dimensão dos desafios ambientais e sociais que as vem assolando como um todo, é crucial que tal medida seja tomada garantindo sua manutenção de forma eficaz, eficiente e dentro de uma perspectiva duradoura.

No que tange a essa perspectiva, há de se atentar para as ações que permitam certificar se as pessoas a serem envolvidas nesse processo estão realmente comprometidas com os objetivos a serem propostos.

Nesse sentido uma investigação sobre a relação supostamente existente entre o comprometimento dos funcionários e a adoção de um SGA, que propicie a criação de um instrumento que permita mensurar o grau de comprometimento dos empregados da Instituição

\footnotetext{
${ }^{8}$ O Método SODA está definido no Apêndice - A deste estudo.

${ }^{9}$ No sentido de problemas nos processos da Pesquisa Operacional (PO)
} 
investigada se faz necessária dada a importância de referido comportamento. Se faz necessária também pela escassez de pesquisas teóricas no Brasil, concernentes ao fenômeno neste estudo investigado.

Pertinente se faz também, por propiciar a identificação antecipada de situações relevantes e preocupações inerentes a qualquer forma de gerir adotada pelas organizações. É certo que não há uma única forma de gerenciar. A organização, por sua dinâmica, estará sempre à procura de soluções diferentes para lidar com a complexidade de problemas advindos de sua própria atuação. Conhecer antecipadamente o comprometimento de seu ativo mais importante quando da adoção de uma gestão diferenciada, no caso desta pesquisa a Gestão ambiental, contribuirá para o alcance de objetivos e politicas a ela inerentes.

Salienta-se que a Instituição investigada, vem passando nos últimos 20 vinte anos por sucateamento de recursos humanos, o número de servidores aposentados superou em muito o número de novos contratados por concurso público, o que torna o presente estudo ainda mais relevante.

Assim servidores remanescentes a serem envolvidos em uma gestão diferenciada deverão estar comprometidos com as profundas mudanças de paradigmas, pois embora não haja competividade em termos de lucratividade por tratar-se de uma Instituição Pública, existe sim a necessidade de se sobressair dentro de sua área de atuação, com o objetivo precípuo de angariar recursos financeiros e de ser reconhecida em sua competência como forma de se destacar no contexto técnico-científico nacional e internacional (pesquisa, produção e formação de recursos humanos), elementos imprescindíveis para o atendimento da missão de referida Instituição

A validação bem como, a aplicação ao longo do tempo do instrumento de mensuração oriundo deste estudo, por meio de estudos longitudinais ${ }^{10}$ futuros, proporcionará tanto aos estudiosos como aos administradores o acompanhamento desses resultados em momentos e locais diferenciados, entendimento esse corroborado por Hair et.al que diz: " $O$ tempo é fundamental em administração. As organizações frequentemente mapeiam o desempenho dos funcionários ao longo do tempo." (Hair et al. 2005, p. 88)

\footnotetext{
${ }^{10}$ Estudos longitudinais usam uma amostra para descrever elementos administrativos. Em vez de descrevê-los em um único ponto no tempo, os dados longitudinais descrevem eventos ao longo do tempo. Os dados longitudinais permitem mapear elementos administrativos de modo que se possam observar as tendências. (Hair et al. , 1005, p. 88)
} 
Quanto à relevância da adoção de uma Gestão Ambiental, se justifica em primeiro lugar pela necessidade de enfrentar os desafios ambientais e sociais percebidos desde a década de 60 como uma crise de dimensão planetária.

Se faz relevante também pela obediência as Leis ambientais concernentes a emissão de poluentes, a disposição de resíduos sólidos e líquidos, a emissão de ruídos e a exploração de recursos naturais. Relevante ainda pela existência de um mercado em crescente processo de conscientização ecológica, como colocado por Nicolella et at (2004).

\subsection{Hipótese}

A hipótese central deste estudo adiantou que a investigação antecipada do comprometimento organizacional influencia na adoção de um Sistema de Gestão Ambiental SGA bem sucedido, assegura também a importância desta prática durante o desenvolvimento de referido sistema, visto que tal comportamento tido como nível do vínculo psicológico de um indivíduo com a organização, implica na resolução do empregado em permanecer ou não empresa.

Entendida como uma afirmação que pode ser desafiada, a hipótese apresentada na presente pesquisa responde as questões: Como? Possibilitando conhecer o comportamento dos indivíduos a serem envolvidos nas atividades inerentes a um SGA; De que modo? Indivíduos com baixo grau de comprometimento ou com comprometimento nulo, não realizarão de forma satisfatória as atividades inerentes a um SGA; e Por quê? Porque somente com um grupo de funcionários comprometidos a implementação de um SGA obterá êxito. $\mathrm{O}$ não comprometimento dos funcionários a serem envolvidos em uma nova gestão implica no desperdício de recurso financeiro. Adotar um SGA requer disponibilidade de orçamento, que se mal administrado leva a organização a perdas muitas vezes irreparáveis.

\subsection{Delimitação}

O estudo limita-se a pesquisar o comprometimento visto como o nível do vínculo psicológico de um indivíduo com a organização, onde esse vínculo tem implicação na resolução do empregado em permanecer na empresa e cuja descrição da natureza do estado psicológico foi tida como: afetiva ${ }^{11}$; instrumental ${ }^{12}$ e normativa ${ }^{13}$ conforme instituído por

\footnotetext{
${ }^{11}$ Comprometimento visto como o resultado de um vínculo afetivo em relação à organização. (Meyer e Allen, 1997).

${ }^{12}$ Comprometimento como resultante de um vínculo que decorre dos custos associados em deixar a organização. (Meyer e Allen, 1997).

${ }^{13}$ Comprometimento visto como uma obrigação em permanecer na organização. (Meyer e Allen, 1997).
} 
Meyer \& Allen (1997). Bem como, limita-se a apontar determinadas questões ambientais, concernentes ao estabelecimento de um Sistema de Gestão Ambiental.

Analisar o comprometimento na perspectiva do vínculo psicológico do indivíduo com a organização, segundo O’Reilly \& Chatman (1986), reflete o grau em que o indivíduo internaliza ou adota características da organização. Conforme Kramer \& Faria (2007), vincular-se significa estabelecer uma relação, um elo com algo ou alguém. De forma mais específica significa uma relação estabelecida pelo indivíduo a partir do seu trabalho, que demonstra o seu grau de ligação com a organização, o grau de envolvimento com os seus projetos e objetivos, assim como o comprometimento com seus problemas, políticas e resultados. (Faria \& Schmitt, 2007)

O fato de um indivíduo estabelecer vínculos com a organização não garante que os objetivos serão atingidos sem obstáculos, mas o compromete com o desempenho e com os resultados obtidos, uma vez que ele se sente efetivamente identificado, pertencente e participante da organização, esse entendimento também é observado por Kramer \& Faria (2007) e Fasolo (2009). 


\section{REVISÃO DA LITERATURA}

Esse capítulo objetiva fundamentar o problema, os objetivos e as hipóteses, e familiarizar tanto o autor desse estudo com os possíveis leitores quanto aos conhecimentos atuais da área a ser pesquisada. Traz um aporte teórico sobre os temas sistema de gestão ambiental, comprometimento, análise e desenvolvimento de opções estratégicas e descreve modelo conceitual.

Concernente ao tópico Sistema de Gestão Ambiental, seguem os subitens Educação Ambiental E.A. e Responsabilidade Social Empresarial, dada a relevância desses dois temas quando da adoção de um SGA.

\subsection{Sistema de Gestão Ambiental}

Sistema de Gestão Ambiental é segundo Dias (2011) o conjunto de responsabilidades organizacionais, procedimentos, processos e meios que se adotam para a implantação de uma política ambiental em determinada organização, ou seja, é segundo esse autor o método empregado para levar uma organização a atingir e manter-se em funcionamento de acordo com as normas estabelecidas, bem como, para alcançar os objetivos definidos em sua política ambiental.

O Sistema de Gestão Ambiental requer, conforme coloca Barbieri (2007) formulação de diretrizes, definição de objetivos, coordenação de atividades e avaliação de resultados.

O modelo sustentável ${ }^{14}$ de gerenciamento SGA está fundamentado em cinco princípios, (Dias et al. 2014), os quais deverão ser obedecidos pelas empresas. São eles:

1. Conhecimento do que deve ser realizado, assegurando o comprometimento com o SGA e definindo a política ambiental;

2. Elaboração de um plano de ação voltado ao atendimento dos requisitos da política ambiental;

3. Condições asseguradas para o cumprimento dos objetivos e metas ambientais e implementação das ferramentas de sustentação necessárias;

4. Realização de avaliações quali-quantitativas periódicas de conformidade ambiental da empresa;

\footnotetext{
${ }^{14}$ Relacionado com as iniciativas para enfrentar os desafios ambientais e sociais, tidos como uma crise de dimensão planetária.
} 
5. Revisão e aperfeiçoamento da política ambiental, dos objetivos e das metas, e as ações implementadas para assegurar a melhoria contínua do desempenho ambiental da empresa.

O termo gestão ambiental é bastante abrangente e é frequentemente usado para designar ações ambientais em determinados espaços geográficos, como por exemplo: gestão ambiental de bacias hidrográficas, gestão ambiental de parques e reservas florestais, gestão de áreas de proteção ambiental, gestão ambiental de reservas de biosfera e outras. (DIAS et al. 2014).

Em gestão ambiental cabe ressaltar também, a importância das condicionantes: a) conscientização social que, segundo Donaire (1992) refere-se à capacidade de uma organização de responder as expectativas e pressões da sociedade, e sobre a qual acrescenta Elgin (1999), ser a qualidade de perceber a realidade a cada momento, mantendo a mente presente em tudo o que se faz, tornando dessa forma a força de trabalho apta para decidir com clareza quais procedimentos a adotar; e b) conceito de responsabilidade social, medido por meio de valores morais de obediência aos preceitos da lei e que segundo Drucker (1969 apud Donaire, 1992) impõe à alta administração a obrigatoriedade de direcionar as ações essenciais no campo social, que devem se originar no topo das organizações.

Quanto a essas duas condicionantes cabem ainda às colocações de Valle que diz: "A conscientização ambiental dos dirigentes de uma empresa pode provocar alterações profundas em suas prioridades estratégicas e algumas mudanças de abordagem que vão modificar as atitudes e o comportamento de todos os seus funcionários." (Valle, 1995, p.14) e a menção de Leonardi (1997) de que não existe a possibilidade de uma ciência única que explique a complexidade da natureza, todos os saberes são necessários para estudar o meio ambiente. Diz o autor: "estudiosos das áreas físicas precisam aprender a trabalhar com aqueles das áreas biológicas e humanas e estes precisam aprender a trabalhar com aqueles das áreas físicas, sem preconceitos." (Leonardi, 1997, p. 253).

Nesse sentido encontra-se o entendimento de interdisciplinaridade no que concerne a tornar-se mais humildes e dispostos ao diálogo efetivo evitando a supremacia e a prepotência. Opinião essa corroborada por Morin, 2001 ao se referenciar a interiorização da tolerância, diz ele: “... o contrário de uma ideia profunda é outra ideia profunda; dito de outra maneira, há uma verdade na ideia antagônica à nossa, e é esta verdade que é preciso respeitar...." (Morin, 2001, p. 102.)

Entendimentos consonantes não foram observados nas primeiras manifestações de gestão ambiental, como bem coloca Barbieri, 2007, quando menciona que essas 
manifestações foram estimuladas pelo esgotamento de recursos, como o caso de escassez de madeira para moradias, fortificações, móveis, instrumentos e combustível cuja exploração havia se tornado intensa desde a era medieval.

Segundo Acot (1990 apud Barbieri, 2007), esses primeiros atos não se caracterizam pela defesa da natureza por ela mesma, mas pelo interesse dos gerentes em preservar os recursos do país tendo em vista sua utilização.

Leonardi (1997) acrescenta ser muito recente a ideia de que a natureza é um bem a ser preservado, pois ele também se acaba, e que o homem tem direito (e dever) de preservála.

Segundo Schmidherny (1992 apud, Corazza, 2003) em empresas japonesas e americanas a responsabilidade geral pela gestão ambiental é confiada a equipes formadas por membros de diferentes divisões ou funções e presididas por um membro da direção geral. $\mathrm{O}$ principal objetivo destas equipes, segundo o autor, é introduzir a gestão ambiental no conjunto das divisões da organização.

Hunt \& Auster (1990) acrescentam que as orientações vindas dos consultores gerenciais, grupos ambientais e associações industriais, para as companhias melhorarem seu desempenho ambiental, sugerem maneiras que podem implementar mudanças estratégicas para moverem-se além da obediência às regulamentações e que assume-se responsabilidade pelos impactos ambientais de seus produtos e ganham credibilidade.

Ressaltam esses autores, que as estratégias ambientais são mais eficientemente implementadas quando elas são consistentes com as características da organização e o contexto de operação da companhia envolvida.

Com relação às variações na cultura e no contexto operacional que interferem implementação de estratégias ambientais na organização, Mintzberg (1979 apud, Hunt \& Auster, 1990) sugere a criação de um sistema gerencial que acomode essas diferenças. Menciona também que disparidades no ambiente encorajam a organização a diferenciar sua estrutura, para criar pockets para lidar com os diferentes aspectos do meio ambiente.

De acordo com Corazza (2003), existem duas formas de integração da gestão ambiental na empresa:

a) Integração pontual da gestão ambiental - caracterizada pela criação da função (ou cargo) e/ou departamento ambiental. "a criação de departamentos de meio ambiente é um fenômeno comum ao menos o que se referem as grandes empresas." (Corazza, 2003 p. 7). 
b) Integração matricial da gestão ambiental - resultante da própria estrutura matricial da ISO 14.000. "a gestão ambiental abrange [...] todos os setores na organização necessários ao planejamento, execução, revisão e desenvolvimento da política ambiental da organização." (Dyllick et al. 2000 apud Corazza, 2003 p. 9).

Corazza (2003) menciona também, algumas formas da Integração matricial da gestão ambiental, registradas na literatura:

a) Integração da gestão ambiental nas atividades de gestão, que segundo Donaire (1999) é a avaliação do ambiente externo para identificar: questões ecológicas; oportunidades e riscos existentes na legislação ambiental; consciência dos consumidores e da sociedade como um todo; comportamento dos concorrentes; avanço tecnológico neste campo;

b) Integração da gestão ambiental nas atividades de inovação, onde Porter et al. (1995 apud, Corazza, 2003) propõem que os esforços de integração da variável ambiental podem resultar em um tipo de inovação que, segundo os autores, oferece a dupla possibilidade de reduzir os custos de entrada em conformidade com a regulamentação e ou construir vantagens absolutas sobre outras organizações;

c) Integração da gestão ambiental nas atividades de produção, onde a área de produção tida por sua natureza transformadora de recursos, como a de maior impacto ambiental é, portanto, aquela onde o envolvimento ambiental é mais explícito;

d) Integração da gestão ambiental nas atividades de recursos humanos, que segundo Donaire (1999) a área ambiental deve desenvolver com a área de Recursos Humanos um intenso programa de conscientização, visto que a atividade de meio ambiente inicia-se e concretiza-se alterando o comportamento das pessoas que a integram (grifo nosso).

A norma ISO 14001 editada no Brasil pela ABNT propõem um modelo de gestão que pretende ser ambientalmente responsável; comprometida com o cumprimento da legislação, com a melhoria contínua e com a prevenção da poluição; baseada no ciclo de melhoria contínua PDCA, descrito na Figura 1. 
Figura 1 - Ciclo PDCA

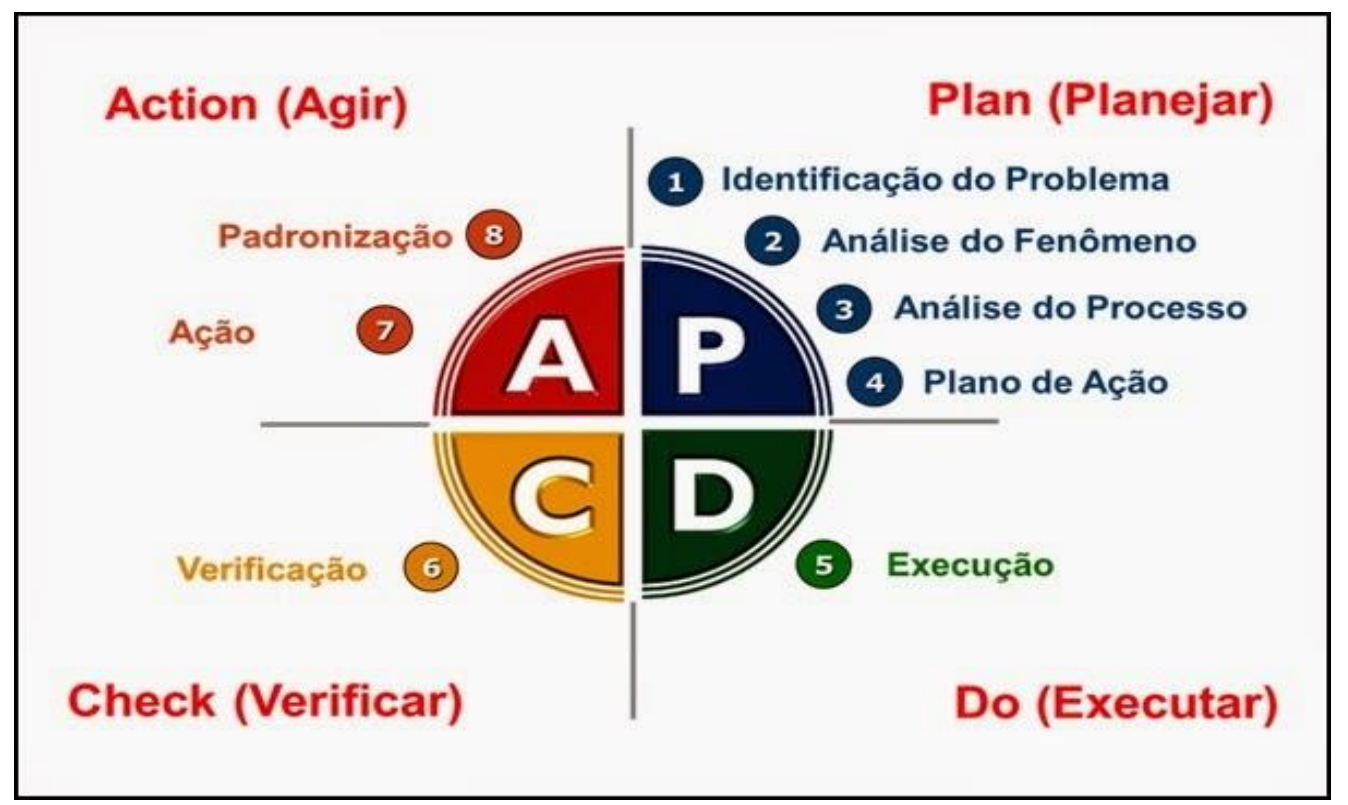

ago.2016

Fonte: Portal Administração. Disponível em: www.portal.administração.com. Acesso em: 01

Baseado no ciclo PDCA encontra-se também o modelo de Sistema de Gestão Ambiental - SGA da família ISO 14000, que conforme Barbieri (2007), tem como ponto de partida o comprometimento da alta administração e a formulação de uma política ambiental. A figura 2 esboça referido modelo. 


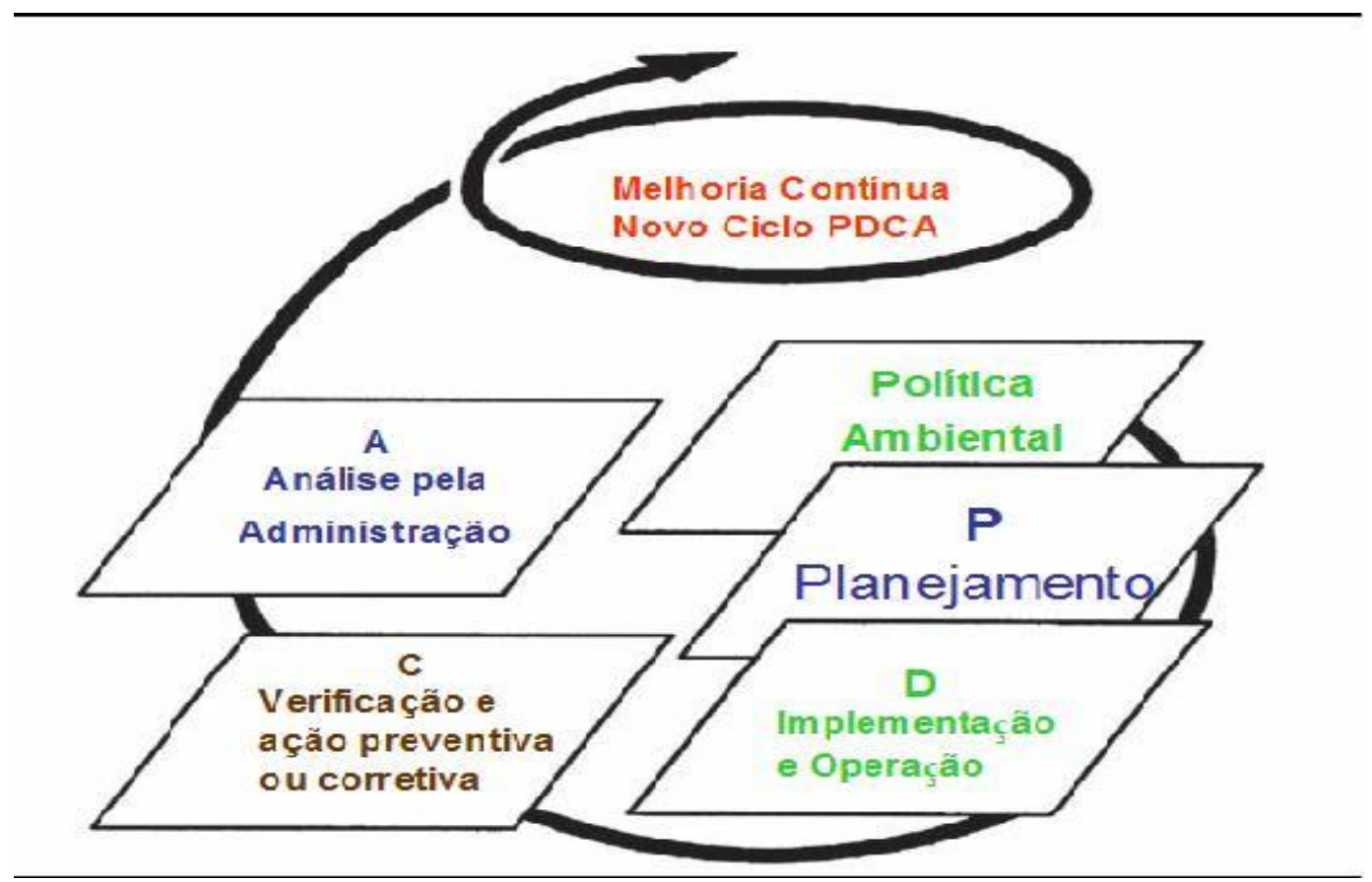

Fonte: GRALTEC Treinamentos. Disponível em: www.graltec.com. Acesso em: 01 ago.2016

Conforme Aquino et.al. (2008) a Norma ISO 14001 destina-se a impor uma nova consciência no sentido de aumentar a percepção das organizações com relação à importância da interação entre a economia e natureza tem como objetivo a criação de um Sistema de Gestão Ambiental que auxilie as organizações a cumprirem os compromissos assumidos com o ambiente natural no sentido de equilibrar a proteção ambiental e a prevenção da poluição com as necessidades socioeconômicas.

Na Figura 3 encontram-se os elementos de um SGA proposto pela Câmara de Comércio Internacional ${ }^{15}$ - Planejamento, Organização, Implementação e Controle.

\footnotetext{
${ }^{15}$ International Chamber of Commerce (ICC) - Entidade não-governamental dedicada ao comércio internacional.
} 
Figura 3 - Elementos de um SGA - Câmara de Comércio Internacional

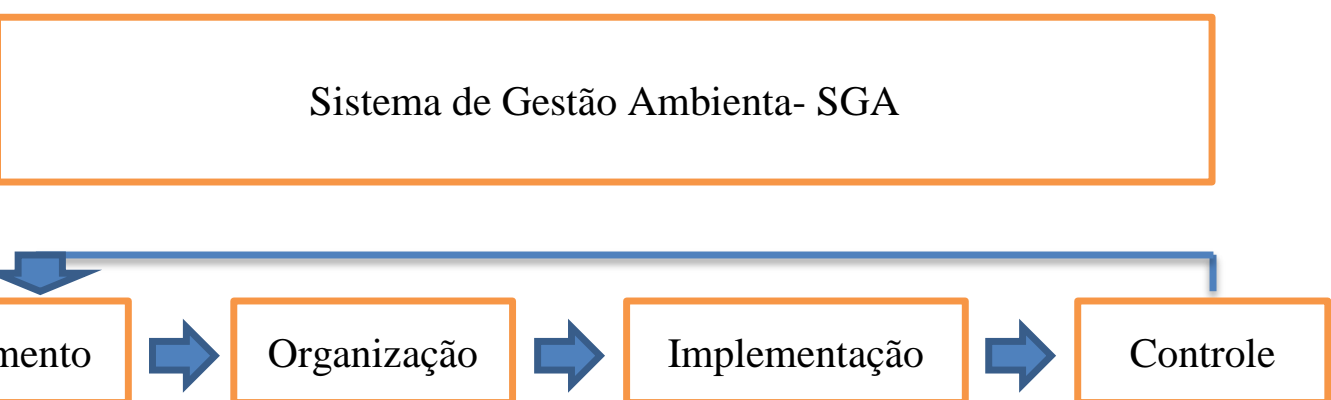

Fonte: Barbieri, 2007, p. 155

Esses elementos compreendem as seguintes ações:

Planejamento: políticas e procedimento; acompanhamento da regulamentação e da sua influência sobre os departamentos da empresa; e processo de planejamento que compreende objetivos e metas e alocação de recursos.

Organização: organização da gestão; estrutura organizacional; delineamento de papeis; e níveis de autoridade e responsabilidade.

Implementação: gerenciamento dos comprometimentos; avaliação e gestão de riscos; revisão de projetos e programas ambientais; programas ambientais específicos; e motivação e delegação.

Controle: gestão do sistema de informação; mensuração dos resultados; diagnóstico dos problemas; auditoria ambiental; e ações corretivas.

2.1.1 Educação Ambiental - E.A.

O coração de um SGA é a identificação e análise dos aspectos e impactos ambientais significativos. Etapas que fundamentam um SGA: Política ambiental, Objetivos e Metas, Programa de Gestão Ambiental e Controle Operacional. O Responsável pela identificação dos aspectos ambientais é quem realiza a tarefa e deverá ser assessorado pelo grupo de implementação devidamente capacitado em metodologia de identificação e análise de aspectos e impactos ambientais.

Para isso o componente educacional se faz importante para os operadores entenderem que sua tarefa está associada a um determinado processo e que nesse processo há entrada e saída de materiais e insumos, que de um modo geral são os próprios aspectos ambientais. (Motta, 1991). Desta forma um programa de educação ambiental deverá atuar de forma ativa no próprio posto dos operadores. 
Em sua proposta sobre educação ambiental, que consiste na conscientização dos aldeões, em uma escola indígena, Dias et al. (2012) descrevem os bons resultados quanto à conscientização ambiental, porém assevera que a prática deve ser uma educação continuada.

Nessa linha de raciocínio encontra-se também o entendimento de Reigota (2001) que nos incita a indagar sobre o que tem sido feito em relação a educação ambiental e como vem sendo propagada sua definição. Segundo o autor a educação ambiental por muitas vezes é tratada como um estudo de ecologia e não no contexto de formar indivíduos mais críticos e participativos. Diz ele que o ambiente escolar é muito importante para a aplicação da educação ambiental, e esta deverá ser inserida em todas as áreas do conhecimento a fim de proporcionar diferentes percepções do mesmo problema, ou seja, deverá ser vista como um assunto interdisciplinar.

Reigota (2001) ressalta também a importância do meio ambiente onde vive o aluno, ou seja, a necessidade de abordar os problemas ali existentes e como podem ser resolvidos, envolvendo dessa forma a comunidade, no intuito de soluções e melhorias. Menciona ainda que a educação ambiental tem contribuído para uma profunda discussão sobre educação contemporânea em geral, visto que concepções vigentes não abrangem a total complexidade do cotidiano desse final de século.

Ao encontro desse entendimento está à concepção de educação ambiental como uma aliada à educação, na qual, poderá ser desenvolvida tanto num ambiente formal (escola) ou até mesmo em outros ambientes não-formais (rua, praça, casa e etc.). Essa educação tem a função de transmitir os valores e conhecimentos por meio do diálogo em sintonia com os ideais da construção de uma sociedade socialmente justa e ecologicamente prudente. $\left({ }^{16}\right)$

Nesse sentido segue a conceituação de Gadoti (2009) quando da alusão ao dever da educação ambiental em ajudar a desenvolver uma consciência ética sobre todas as formas de vida com as quais compartilha-se este planeta, respeitando seus ciclos vitais e impondo limites a sua exploração pelos seres humanos.

Sato \& Carvalho (2008) discorrem sobre Educação Ambiental, mencionando que o percurso percorrido para a conclusão de seus apontamentos se dá dentro de matérias incertas/polemicas. Em seus estudos mencionam as colocações dos autores: Sauvé (2008, apud Sato \& Carvalho, 2008) ... diferentes maneiras de conceber e praticar a E.A. não busca hegemonias, permiti sim a escolha livre no voo de cada pessoa e reconhece que os itinerários

\footnotetext{
${ }^{16}$ Consciência Politica. Disponível em: www.portalconscienciapolitica.com.br - Acessado em: 18 jan.2016
} 
são construídos e ou reconstruídos pelas experiências dos sujeitos; Grun (2008, apud Sato \& Carvalho,2008) ... alerta para o poder crítico das interpretações, evocando cuidados responsáveis e o despertar do sentido crítico de cada pessoa naquilo que lê, interpreta e vivencia; Charlot \& Veleida (2008, apud Sato \& Carvalho,2008) ... pensar e fazer a E.A. pela relação da natureza com a educação ambiental; Gaudiano (2008, apud Sato \& Carvalho, 2008) ... aponta a reflexão sobre os desafios de um trabalho interdisciplinar na E.A. reafirmando a interdisciplinaridade como um dos traços constitutivos do campo da E.A.. Nesse sentido está também a posição de Reigota (2001); e Pérez (2008, apud Sato \& Carvalho, 2008) ... na decisão por uma formação dos profissionais ambientais, baseada nas competências da ação, saindo de uma perspectiva ingênua e propondo uma atitude mais profissional que considere os avanços da pesquisa e a profissionalização da E.A.

Essas autoras propõem que para os processos de constituição da identidade profissional do educador ambiental se faz necessário pensar a E.A. como uma das práticas articuladoras das identificações dos sujeitos na formação de um ideário ecológico.

Dentre tantas colocações concernentes a pesquisa sobre E.A., encontra-se também o tema educação no processo de gestão ambiental, proposta iniciada por pesquisadores do IBAMA em 1995. Essa proposta se deu juntamente com outros novos nomes para a prática educativa referente ao meio ambiente na década de 90, tais como: Educação para o Desenvolvimento Sustentável (Neal, 1995), Ecopedagogia (Gadotti, 1997), Educação para a Cidadania (Jacobi, 1997a) e Educação para Gestão Ambiental (Quintas \& Gualda, 1995).

A proposta do IBAMA de 1995 segundo Layrargues (2004) exige profissionais especialmente habilitados, que dominem conhecimento e metodologias específicas para o desenvolvimento de processos de ensino-aprendizagem com jovens e adultos em contextos sociais diferenciados, acrescenta ainda a necessidade de compromissos com segmentos da sociedade brasileira que, segundo esse autor, na disputa pelo controle dos bens naturais do país, historicamente são sempre excluídos dos processos decisórios e ficam com o maior ônus.

\subsubsection{Responsabilidade Social Empresarial}

As empresas ao optarem pela implantação de um SGA, devem ter como premissa que organizações não se baseiam somente em problemas econômicos. Elas devem ter o entendimento de que estão inseridas em um ambiente complexo, onde suas atividades 
influenciam e tem impacto sobre diversos agentes sociais, comunidade e sociedade. Tenório (2006).

Como coloca, Heitor Chagas de Oliveira, Diretor executivo de Recursos Humanos - Petrobrás, em suas menções concernente a obra de Tenório (2006), a responsabilidade social empresarial, em nome do ressurgimento da ética como referencial de convívio, torna-se fator de avaliação e preferência para investidores institucionais que operam nas grandes bolsas de valores. Agregado a esse fator e preferência, pesquisas diversas revelam a preferência dos consumidores em marcas vinculadas a obras admiráveis. Diz Tenório:

"Não é mais aceitável que o convívio com empregados e sua realidade humana e socioeconômica seja limitado ao pagamento de salários. A convivência e as relações com as comunidades, de onde as empresas retiram tanta energia e às quais muitas vezes agridem com o seu gigantismo ou com fortes impactos na organização de sua vida, terão que ser objeto de transparentes e legítimas negociações." (Tenório, p. 6, 2006)

A base conceitual contemporânea da responsabilidade social empresarial está associada aos valores requeridos pela sociedade pós-industrial ${ }^{17}$, nela existe o entendimento de que as organizações estão inseridas em ambiente complexo, onde suas atividades influenciam ou tem impacto sobre diversos agentes sociais, comunidade e sociedade, acrescenta ainda que atender apenas aos interesses dos acionistas não é suficiente dada a necessária incorporação de objetivos sociais no plano de negócios como maneira de integrar as organizações à sociedade.

A continuidade da companhia, no longo prazo, passa a depender da capacidade da administração para atender os anseios da sociedade e incluir as expectativas de outros agentes, além de empregados, acionistas e governo, em seu plano de negócios. (Tenório, p. 21, 2006).

Afirma ainda, que com os requisitos da tecnologia, o acionista tem seu poder reduzido, devido a grande necessidade de capital e conhecimentos técnicos especializados. Aliado a esse entendimento encontra-se a colocação de Galbraith (1982);

Dada a concordância de ser o crescimento econômico um objetivo social, o objetivo da tecnoestrutura tem um forte propósito social. Seus membros podem identificar-se com ela, seguramente cônscios de que estão servindo a uma finalidade maior que a deles. Eles procuram promover o crescimento da firma. Isso promove o crescimento da economia. A identificação, como

\footnotetext{
${ }^{17}$ Sociedade pós-industrial, no contexto da evolução sociocultural, é o nome proposto para uma economia que passou por uma série de mudanças específicas, após o processo de industrialização. O conceito foi introduzido pelo sociólogo e professor emérito da Universidade de Harvard Daniel Bell na sua obra The Coming of Post Industrial Society: A Venture in Social Forecasting de 1973.
} 
motivação, reforça o interesse próprio associado a essa expansão. (GALBRAITH, p. 36, 1985).

Literatura mais recente fornece três interpretações conceituais para responsabilidade social empresarial; são elas:

a) cumprimento das obrigações legais e o comprometimento com o desenvolvimento econômico;

b) designação do envolvimento da empresa em atividades comunitárias; e

c) uma série de compromissos da empresa com a sua cadeia produtiva: clientes, funcionários, fornecedores, comunidades, meio ambiente e sociedade (Instituo Ethos de Empresas e Responsabilidade Social - 2013).

Dada essas interpretações assume-se para esse estudo o entendimento de que a Responsabilidade Social Empresarial liga-se a uma gestão ética e transparente que a organização deve ter com suas partes interessadas, para minimizar seus impactos negativos no meio ambiente e na comunidade. Nesse sentido estão os indicadores de Responsabilidade Social que permitem que as empresas verifiquem o seu nível de envolvimento com as questões sociais.

Indicadores de Responsabilidade Social, de acordo com dados do Instituto Ethos de Empresas e Responsabilidade Social são ferramentas que vem auxiliando as empresas no sentido de permitir a incorporação em sua gestão dos conceitos e compromissos que assumem em favor do desenvolvimento sustentável. Para o presente estudo foi detalhado o grupo de seis indicadores de responsabilidade social, concernente ao tema Valores, Transparência e Governança, conforme apresentado nas figuras, 4, 5, 6, 7, 8 e 9. Essa escolha deu-se pelo entendimento de que referidos indicadores são os que mais se aproximam da situação problemática trabalhada no mapa cognitivo que teve como resultado de sua análise a necessidade de se identificar elementos que favoreçam a implementação de um Sistema de Gestão Ambiental bem sucedido. 


\section{Figura 4 - Compromisso Éticos}

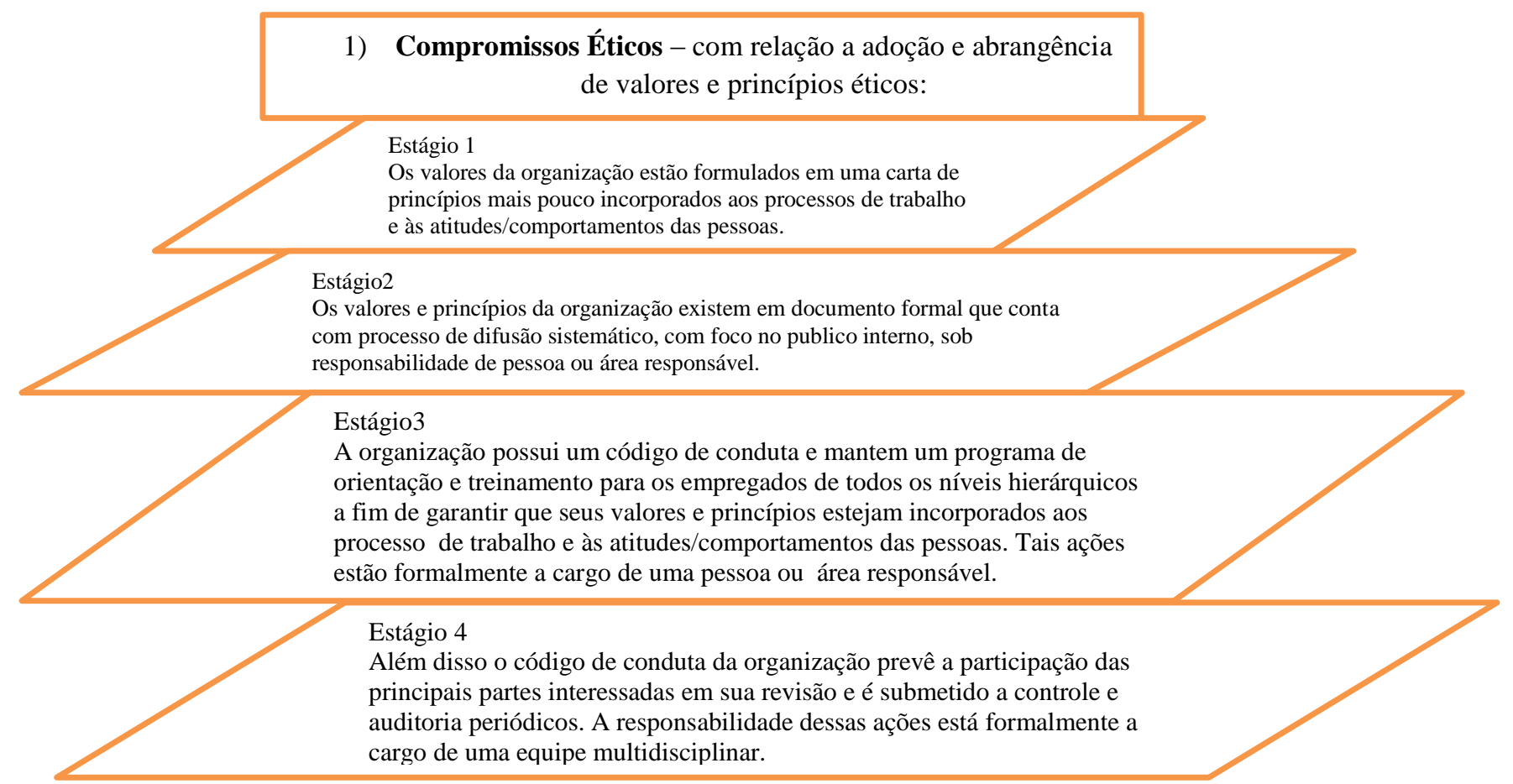

Fonte: adaptado Modelo Instituto Ethos de empresas e Responsabilidade Social (2013)

\section{Figura 5 - Enraizamento na Cultura Organizacional}

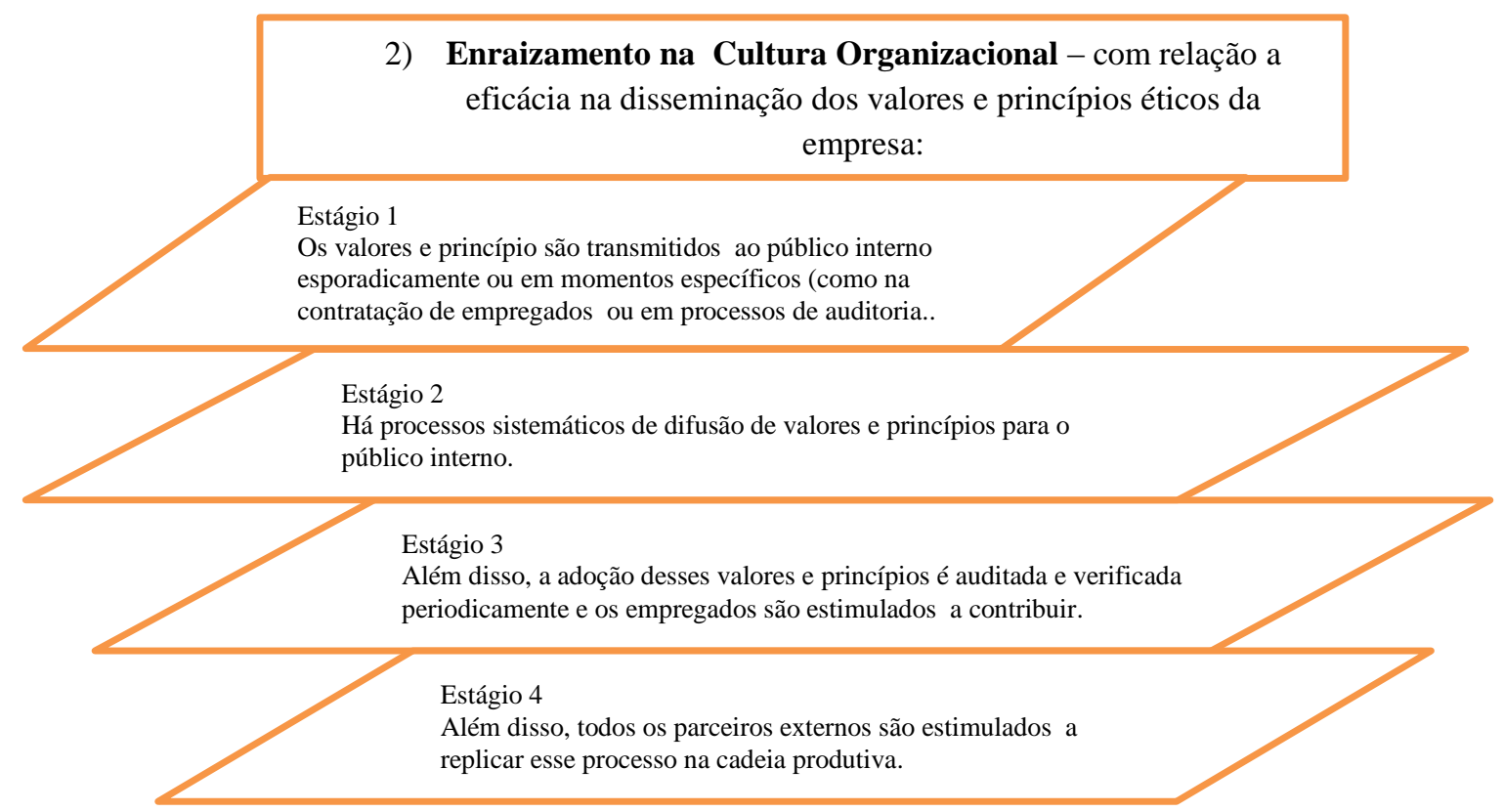

Fonte: adaptado Modelo Instituto Ethos de empresas e Responsabilidade Social (2013) 


\section{Figura 6 - Governança Corporativa}

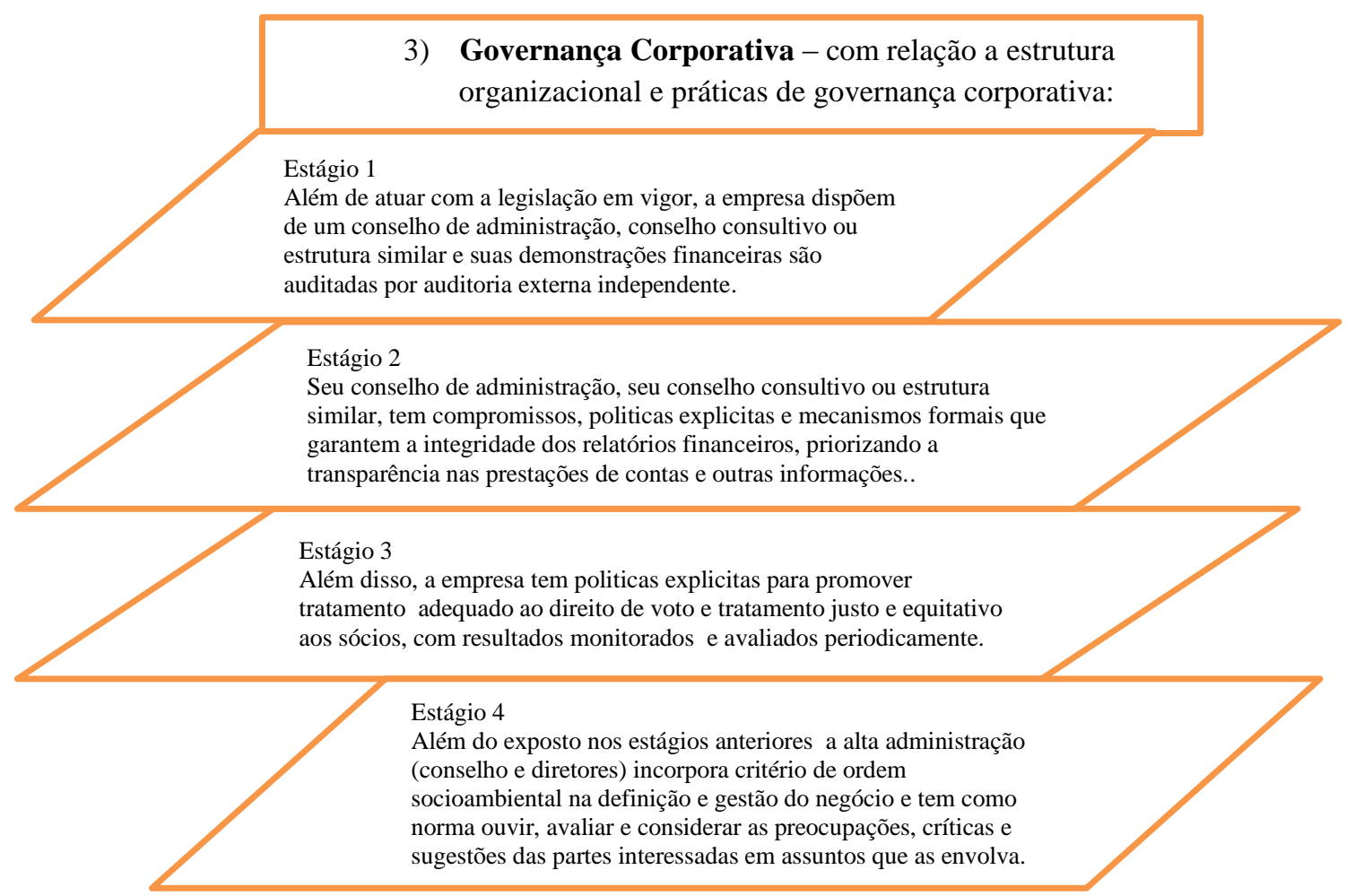

Fonte: adaptado Modelo Instituto Ethos de empresas e Responsabilidade Social (2013)

Figura 7 - Relações com a Concorrência

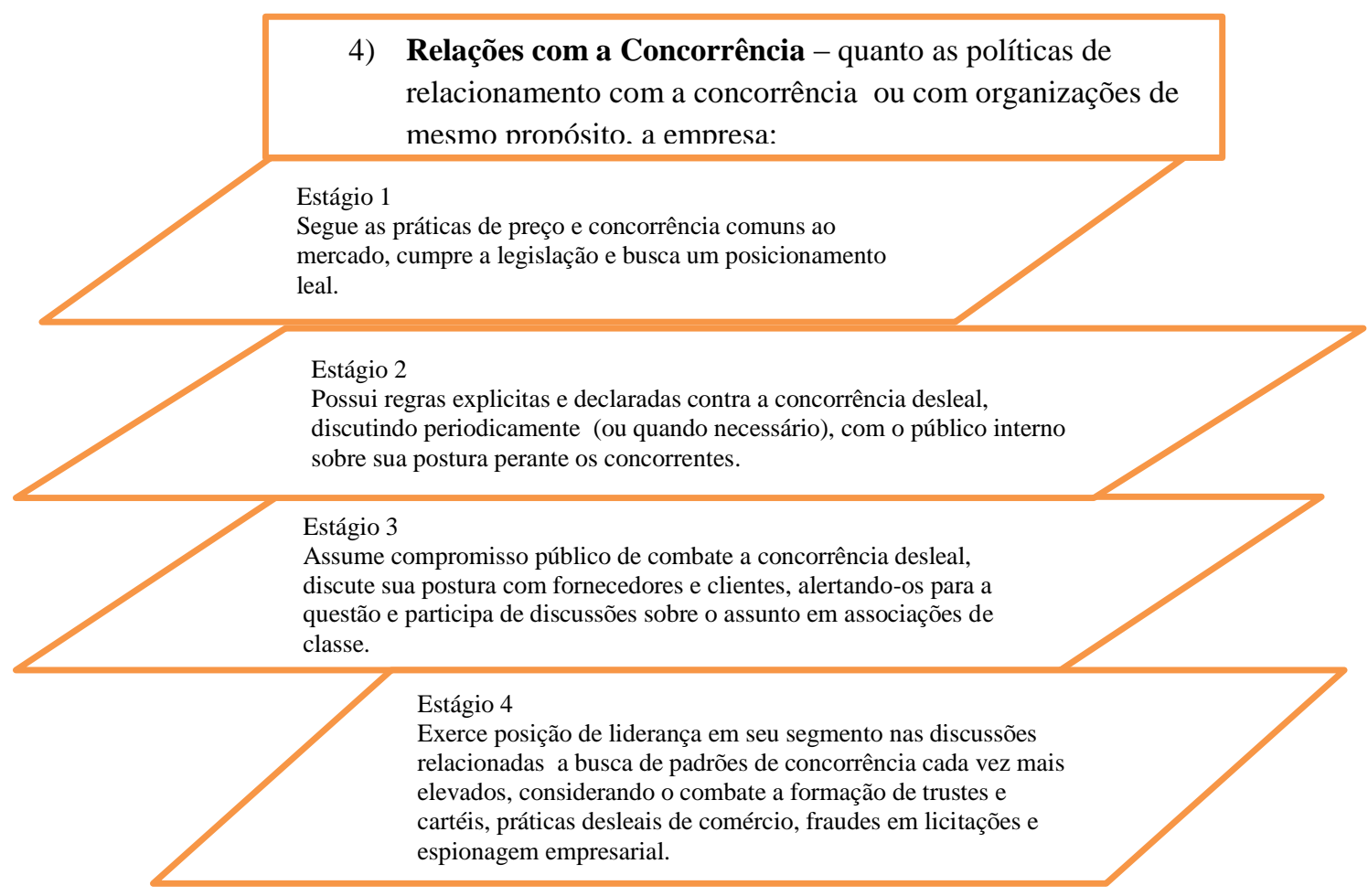

Fonte: adaptado Modelo Instituto Ethos de empresas e Responsabilidade Social (2013) 
Figura 8 - Diálogo e engajamento das partes interessadas

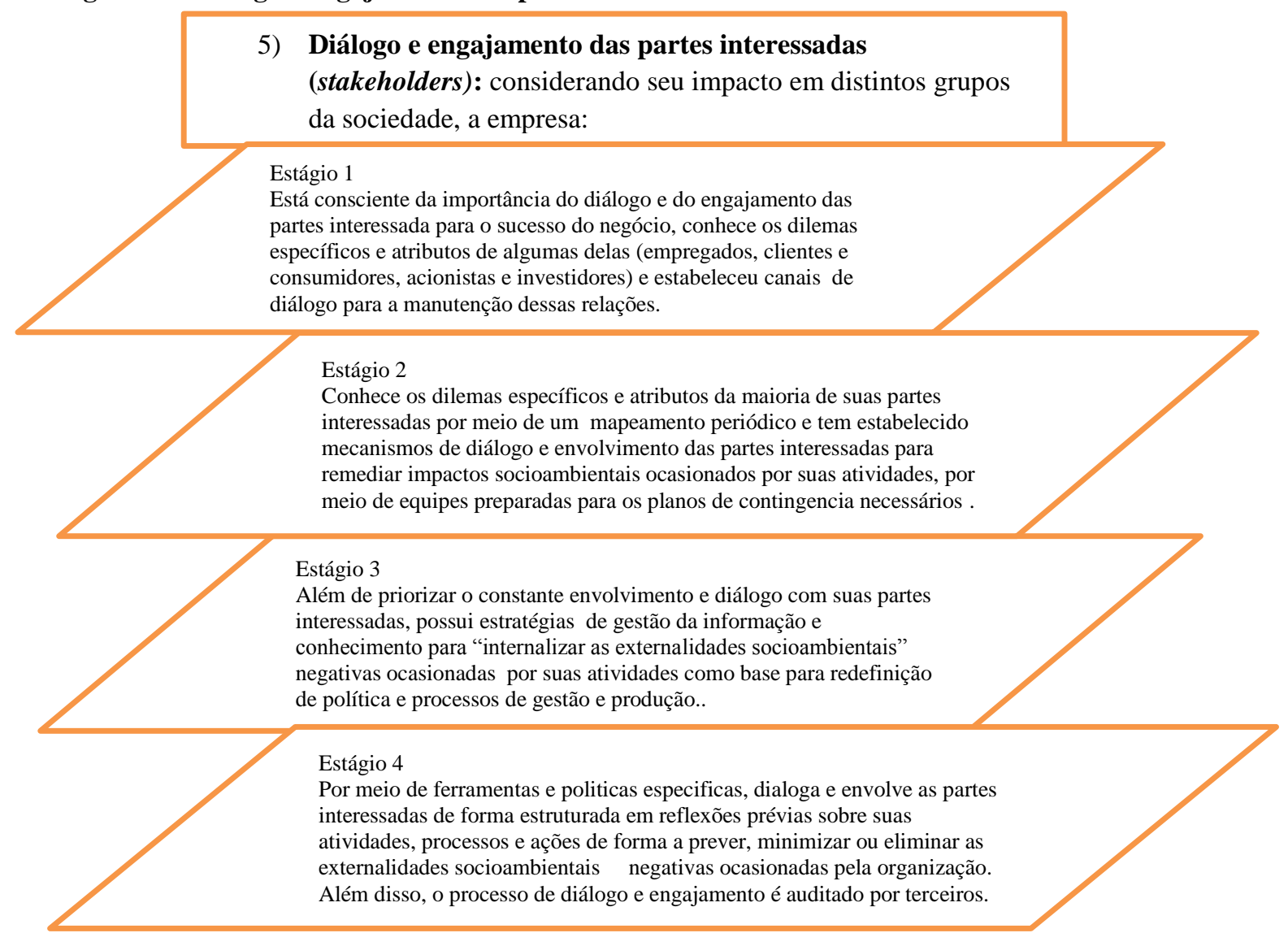

Fonte: adaptado Modelo Instituto Ethos de empresas e Responsabilidade Social (2013)

Figura 9 - Balanço Social

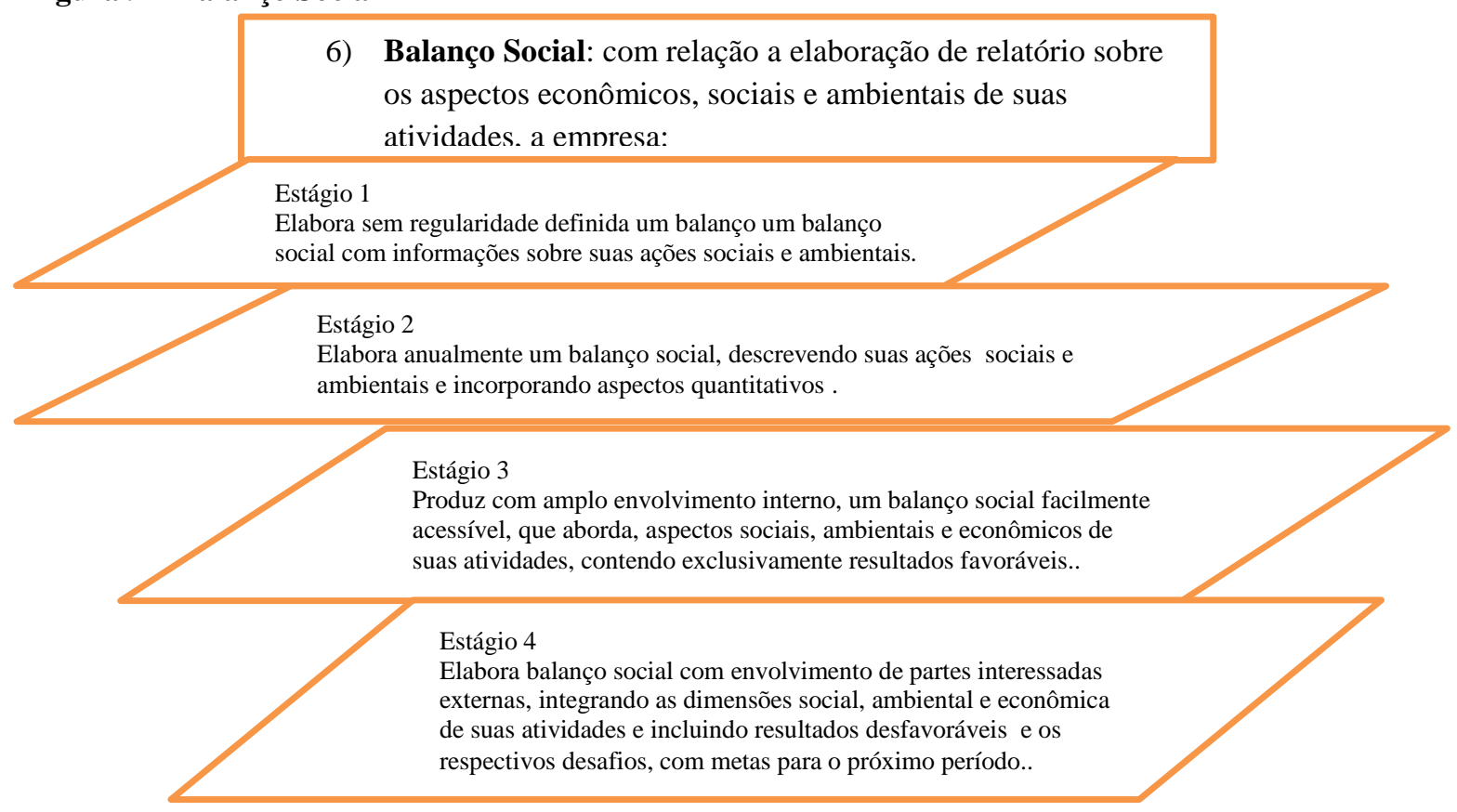

Fonte: adaptado Modelo Instituto Ethos de empresas e Responsabilidade Social (2013) 


\subsection{Comprometimento organizacional}

A importância do comprometimento mencionado por Barbieri (2007), quando de sua abordagem sobre Sistema de Gestão Ambiental, é apontada nesse trabalho como relevante não somente por parte da alta direção, mas também pelos demais funcionários da organização. Essa abordagem se dá pelo entendimento da necessidade de todos os envolvidos nas atividades concernentes a um SGA estarem comprometidos. Nesse sentido uma averiguação sobre o comprometimento organizacional de faz necessária.

Os finais do século XX, como bem coloca Medeiros (2003), mostram o reaparecimento da Gestão de Pessoas, como avanço para o desempenho empresarial entendimento esse também mencionado por Pfeffer \& Veiga (1999). Bastos (1992, 1993, 1994 e 1995) destaca a busca das empresas por qualidade e produtividade, bem como, demonstra sua busca em atrair e manter os profissionais mais competentes (1993), consideração essa já tida por Harman \& Hormann (1990).

Até o presente momento as empresas continuam empregando grandes esforços na investigação da retenção de pessoas melhor qualificadas e que também estejam comprometidas com as organizações. Os processos de recrutamento e seleção de pessoal tentam, mais do que nunca, prover as empresas com indivíduos comprometidos e com desempenho superior. (Medeiros, 2003). Além das despesas com processos de seleção, os programas de retenção de talentos contribuem com a elevação dos custos consequentes dos benefícios e salários oferecidos pelas organizações, como assinala O’Reilly \& Pfeffer (2001, apud Medeiros, 2003).

Ainda são evidenciadas lacunas que a pesquisa do comprometimento deve percorrer, no entanto, dentro do presente contexto a pesquisa do comprometimento tem evoluído como pode ser observado em diversas pesquisas abordando o comprometimento como um constructo multidimensional, ou seja, tentando entender os indivíduos e seu vínculo com a organização. (Medeiros, 2003; Borges \& Pilati, 1999; Bandeira et al. 1999; Bastos \& Borges, 1995 e 1999). Consenso de que o comprometimento possui múltiplos focos como organização e carreira, e bases como afetiva, instrumental e normativa já podem ser observados na Literatura. (Bastos \& Borges, 1999; Bastos et al. 1996; Bastos \& Brandão, 1999; Bastos \& Pereira 1997; Bandeira et al. 1999, Chang 2003; Kramer \& Faria, 2007; Menezes \& Bastos, 2011; Horn \& Cerutti, 2013).

Salienta-se no entanto que o comprometimento, neste estudo a ser tido como estratégia para a implementação de um Sistema de Gestão Ambiental é o visto como nível do 
vínculo psicológico de um indivíduo com a organização, onde esse vínculo tem implicação na resolução do empregado em permanecer na empresa e cuja descrição da natureza do estado psicológico foi tida como: afetiva'; instrumental' e normativa conforme instituído por Meyer \& Allen (1997).

\subsubsection{Noções conceituas do comprometimento organizacional}

Esse tema com relevância nas discussões sociológicas, "Sociólogos fazem uso do conceito de comprometimento quando estão tentando contabilizar o engajamento das pessoas que agem em consistentes linhas de atividade." (Becker, 1960, p.34), possui três enfoques conceituais predominantes, os enfoques afetivo, instrumental e normativo. Esses três enfoques foram tratados em algumas pesquisas isoladamente, como é o caso do enfoque afetivo (Mowday et al, 1979 e Mowday et al, 1982), ou em modelos multidimensionais, como é o caso do modelo de conceitualização de três componentes do comprometimento organizacional e ocupacional pelos pesquisadores Meyer \& Allen (1991). Neste estudo serão apresentadas os enfoques multidimensionais nomeados pelos referidos autores como: afetivo, instrumental e normativo.

\subsubsection{Afetivo}

Esse enfoque foi o que dominou a literatura do comprometimento organizacional por maior tempo, iniciou-se com as pesquisas desenvolvidos pela equipe de Lyman Porter (Mowday et al, 1979 e Mowday et al, 1982). Tais trabalhos apesar de reconhecerem a existência de uma corrente comportamental para definir o comprometimento (Medeiros, 2003), assumem o comprometimento numa perspectiva atitudinal. Para os autores esse tipo de comprometimento representa mais do que a simples lealdade passiva para com a organização, ele envolve um relacionamento ativo no qual o empregado coloca algo de si próprio em busca do bem-estar da organização. (Tamayo, 2005)

Mowday et al, 1979 utilizaram a definição elaborada por Poter \& Smith (1970), para definir o comprometimento:

"comprometimento é uma relação forte entre um indivíduo identificado com e envolvido numa organização em particular, e pode ser caracterizado por pelo menos três fatores: (1) estar disposto em exercer um esforço considerável em benefício da organização; (2) uma forte crença e aceitação dos objetivos e valores da organização; e (3) um forte desejo de se manter membro da organização." (Mowday et al, 1979, p.226)

Os trabalhos desenvolvidos por Mowday et al (1982) iniciados na década de 70 culminaram na validação do instrumento Organizational Commitment Questionaire - OCQ 
(Mowday et al., 1979), o qual mensura o comprometimento. Este modelo de mensuração foi montado com a definição de comprometimento por eles estabelecida.

Esses estudiosos reconheciam que o comprometimento também era pesquisado num enfoque comportamental, chegando a destacar os trabalhos de Staw \& Salancik (1977/1978 apud Mowday et al., 1982), no entanto, construíram um instrumento considerando apenas a perspectiva atitudinal. Bastos (1994) e Menezes \& Bastos (2011) tecem uma opinião desfavorável a esse respeito, quando assinalam que ao se propor um novo conceito muitos pesquisadores abandonam outros que vinham sendo utilizados. Salancik (1977, apud Mowday et al., 1982) define o comprometimento numa perspectiva comportamental. Para o autor, comprometimento é "um estado de ser em que um indivíduo torna-se levado por suas ações e por meio dessas ações acredita que elas sustentam as atividades de seu próprio envolvimento". (Salancik,1977 apud Mowday et al., 1982, p. 2426).

Dentro dessa linha de pesquisa observa-se que OCQ é um instrumento bastante utilizado e tem característica de medir o comprometimento atitudinal, também denominado de afetivo. Ele foi validado utilizando um banco de dados com 2563 empregados e obteve um índice de consistência interna ou Alpha de Cronback de “ $\alpha=0,90$ ”. A partir de então essa escala passou a ser o instrumento mais utilizado para se medir o comprometimento, (Mathieu $\&$ Zajac, 1990). A escala é formada por quinze indicadores de comprometimento, possuindo uma versão reduzida com nove itens. A escala OCQ é do tipo likert, podendo ser utilizada com 7 ou 5 pontos, variando de discordo totalmente e concordo totalmente, originalmente foi aplicada com 7 pontos, mas alguns estudos a utilizam com apenas 5.

Borges et al. (1989) validaram referido modelo de mensuração como índice de consistência de $\alpha=0,80$.

\subsubsection{Instrumental}

$\mathrm{O}$ enfoque instrumental do comprometimento organizacional deriva-se dos estudos de Becker (1960). O autor traça o comprometimento instrumental como uma tendência do indivíduo em se engajar em linhas consistentes de atividade. Esse comprometimento também é chamado de side bet, que pode ser traduzido como trocas laterais, assumindo diversos outros rótulos, conforme observado por Medeiros (2003), tais como calculativo e continuação. O indivíduo permanece na empresa devido a custos e benefícios associados a sua saída, que seriam as trocas laterais. (Becker, 1960) 
Refere-se a disposição do empregado em permanecer na organização no sentido de não perder os investimentos pessoais nela realizados. Neste aspecto acrescenta Tamayo (2005) que as alternativas de trabalho no mercado constituem também uma fonte importante do comprometimento instrumental, menciona ainda que nessa perspectiva o comprometimento demonstra ser uma consequência da necessidade que o empregado tem da organização.

O comprometimento, para Hrebiniak \& Alluto (1972), é visto como um fato estrutural resultante das transações indivíduo-organização e das alterações nos benefícios adquiridos e investimentos realizados pelo indivíduo em seu trabalho ao longo do tempo, tidos como side bets, conforme denominação de Becker (1960). Assim, como mencionado por Medeiros (2003) a noção de linhas consistentes de atividades implica uma escolha por parte do indivíduo, de um curso de ação, dentre diversas alternativas, daquela que melhor atende a seus propósitos.

Estudos como os de Allen \& Mayer (1990) encontram alta correlação entre comprometimento instrumental, planos de aposentadoria e investimentos realizados pelos empregados. Trabalhos diversos evidenciam empiricamente correlações entre comprometimento instrumental em indicadores relacionados a investimentos realizados pelos indivíduos no trabalho e também com alternativas de trabalho. (Medeiros, 2003; Borges \& Pilati, 1999; Bandeira et al. 1999; Bastos \& Borges, 1995/1999; Bastos \& Borges, 1999; Bastos et al. 1996; Bastos \& Brandão, 1999; Bastos \& Pereira 1997; Bandeira et al. 1999; Chang, 2003, Menezes \& Bastos, 2011).

A pesquisa desenvolvida por Alluto et at. (1973) dá suporte à teoria side bet de Becker (1960), comprovada principalmente pelas variáveis idade e experiência de trabalho, bem como, da presença de planos de aposentadoria e fundos de pensão.

No entanto, ressalta-se que o comprometimento instrumental operacionalizado pela escala desenvolvida por Ritzer \& Trice, (1969 apud Hrebiniak \& Alluto, 1972) composta pela pergunta aos respondentes, "se eles definitivamente mudariam de emprego $e$ organização; ou estavam indecisos; ou definitivamente não mudariam se não recebessem um pequeno aumento ou um grande aumento, em relação a cinco variáveis: salário; função; status; responsabilidades e oportunidade de crescimento", Ritzer \& Trice, (1969 apud Hrebiniak \& Alluto, 1972), não conseguiu ser mensurado e nem ser relacionado a referido comprometimento. 


\subsubsection{Normativo}

O componente normativo do comprometimento foi identificado após o trabalho de McGee \& Ford (1987), que examina as propriedades psicométricas das escalas desenvolvidas por Meyer \& Allen (1984) para medir os comprometimentos afetivo e instrumental.

McGee \& Ford (1987) encontraram três fatores distintos: o primeiro formado com indicadores da escala afetiva; o segundo formado por indicadores que denotavam a existência de poucas alternativas de emprego para o empregado; e o terceiro fator que reunia indicadores que refletiam o comprometimento baseado no sacrifício pessoal associado a possibilidade de deixar a organização. As contribuições desse trabalho, marcaram a literatura do comprometimento, sendo este estudo considerado um importante marco para a operacionalização do comprometimento. (Medeiros 2003)

Wiener (1982), conceitualiza o comprometimento como "a totalidade das pressões normativas internalizadas para agir num caminho que encontra os objetivos e interesses organizacionais.” (Wiener, 1982, p. 421). A autora ressalta que aceitar os valores e objetivos organizacionais, representa uma forma de controle sobre as ações das pessoas, a qual denomina enfoque normativo-instrumental. Segundo Wiener (1982), indivíduos comprometidos dentro de um enfoque normativo exibem determinados comportamentos porque acreditam que é certo e moral fazê-lo. Esse sentimento de obrigação decorre de controles normativos da organização, tais como missão, normas, regulamentos entre outros. (Tamayo, 2005)

O estudo de Wiener (1982) derivou do Modelo de Intenções Comportamentais estabelecido por Fishbein (1967, apud Medeiros, 2003). Esse modelo objetiva predizer e compreender as intenções comportamentais dos indivíduos. Wiener (1982) menciona também que o comportamento do indivíduo é determinado basicamente por dois fatores, o atitudinal e o normativo. Atitudinal onde a atitude acerca de uma ação é um resultado da avaliação dos efeitos desta ação e o normativo, onde o comportamento na organização é função da percepção da totalidade das pressões normativas a respeito do comportamento, colocação essa também citada por Medeiros (2003).

Medeiros (2003) cita ainda que pressões normativas, são provenientes da cultura da empresa, que impõe a ação e o comportamento na organização e que a visão normativa do comprometimento sugere um foco centrado nos controles normativos por parte das organizações, tais como normas e regulamentos ou também como uma missão forte e disseminada dentro da organização. 
A mensuração do comprometimento normativo foi testada de modo bastante simples por Allen \& Meyer (1990). O comprometimento normativo foi avaliado por meio de três indicadores. Aos respondentes eram perguntados em que extensão eles sentiam que um indivíduo deveria ser leal a sua organização; deveria fazer sacrifícios em benefício da organização; e não deveriam criticar a organização.

Allen \& Meyer (1990) desenvolveram uma primeira escala para mensurar o comprometimento normativo, tentando mostrar evidências da conceitualização de três componentes do comprometimento organizacional. Em um segundo trabalho, Meyer \& Allen (1991) apresentaram um modelo validado, com novos indicadores de comprometimento normativo, e reconhecido pela literatura do comprometimento. Mathieu \& Zajac (1990), apontam os pesquisadores Meyer \& Allen como os mais importantes pesquisadores do comprometimento da década de 90.

Meyer \& Allen (1997), cujo modelo de mensuração serviu como base para a elaboração do instrumento de mensuração do comprometimento proposto no presente estudo, definem o comprometimento em três componentes:

Afetivo: comprometimento como um apego, como um envolvimento, onde ocorre a identificação com a empresa. "empregados com forte comprometimento afetivo permanecem na organização porque querem.” (Meyer e Allen, 1991);

Instrumental: comprometimento percebido como custos associados em deixar a organização. "empregados comprometidos instrumentalmente permanecem na empresa porque precisam." (Meyer e Allen, 1991);

Normativo: comprometimento como uma obrigação em permanecer na organização. "empregados com comprometimento normativo permanecem na empresa porque sentem que tem essa obrigação.” (Meyer e Allen, 1991).

\subsection{Análise e desenvolvimento de opções estratégicas}

A proposta do comprometimento como estratégia para a adoção de um SGA considerou o contexto de uma das seis características estudadas em Gestão Estratégica de Pessoas, colocadas por Miranda (2011). Característica que leva e consideração a relevância da totalidade das pessoas na organização e não somente os altos executivos e ou pessoal operacional. 
No entanto segue também uma breve explanação sobre análise e desenvolvimento de opções estratégicas voltadas não somente para a maximização dos lucros mas também para os elementos sociais, políticos e culturais, dado entendimento desses elementos estarem diretamente ligados ao Sistema de Gestão Ambiental.

A essência da estratégia segundo Porter, (1996 apud Bertero et al, 2003) é posicionar a empresa o tempo todo em seu ramo de atividade. Ainda segundo esses autores o sistema de informação e o formato dos instrumentos de gestão estratégica apresentam dados que permitem comparar o desempenho da empresa com os seus concorrentes a partir de uma diversidade de variáveis ou aspectos.

Segundo modelo de classificação de Whittington (2001) o qual se baseia em uma matriz de classificação bidimensional a orientação da estratégia empresarial pode ser focada no lucro ou em objetivos mais diversos, pluralistas e no processo de decisão que pode ser deliberado e intencional ou emergente.

A combinação dessas duas dimensões, dá origem, conforme coloca Bertero et al. (2003) a quatro perspectivas no pensamento estratégico, que são:

a. Clássica - caracterizada por focar a maximização de lucros a partir de uma visão intencional e deliberada;

b. Evolucionária - afirma que a estratégia no sentido clássico de planejamento racional orientado para o futuro é frequentemente irrelevante;

c. Processual - afirma que dadas às dificuldades inerentes de previsão de futuro o planejamento de longo prazo é pouco útil; $e$

d. Sistêmica - tem como elemento chave o encaixe social da atividade econômica. (Bertero et al. 2003)

A abordagem sistêmica segundo Bertero et al. (2003), propõem que os objetivos e as práticas da estratégia dependem do sistema social específico no qual o processo de desenvolvimento estratégico está inserido. Mencionam os autores: “... os estrategistas podem se desviar, e frequentemente se desviam dos padrões formais de maximização do lucro. Elementos sociais, políticos e culturais criam interesses além do lucro ..." (Bertero et al., p. 53, 2003). Esse entendimento exemplifica interesses de grupo e orgulho profissional.

Alinhado a essa perspectiva encontra-se o entendimento de Buarque (1993) em relação aos caminhos a serem seguidos na busca do progresso humano. Menciona o historiador que o conservadorismo dos economistas no sentido de estarem presos aos propósitos, à racionalidade e aos limites do objeto social que estudam dificultará a formulação de um novo pensamento, o qual segundo ele, partirá dos economistas que se associarem as 
demais áreas do conhecimento, onde ética, ecologia e economia se associam para definir um propósito, abrangência e racionalidade de um novo momento.

Assevera Buarque:

Mesmo economistas que percebem as limitações de seu conhecimento reagem a novas ideias dizendo que este novo pensamento se afasta do propósito em si da ciência econômica: estudar como o mundo social produz e distribui, sem levar em conta o resto do mundo nem fornecer juízos de valores sobre o processo. Negam-se a estudar a relação homem-natureza e o propósito civilizatório, com medo de, na procura de uma nova, perder toda forma de racionalidade. Ao abrir o pensamento a outras áreas, perder o rumo da própria ciência que escolheram. Esquecem que nos momentos de crise nenhuma área do conhecimento encontra resposta dentro de seus modelos; e nenhum novo caminho é encontrado sem se estar perdido ao menos no segundo antes de encontra-lo. (Buarque in Bursztyn p.59, 1993)

Concernente a proposta de estratégia adotada neste estudo faz-se necessário atentar de forma mais específica para estratégia de gestão de pessoas, por ter sido dentro do contexto de uma de suas características a definição aqui utilizada, ou seja, a de levar em consideração a relevância da totalidade dos indivíduos nas organizações e não somente os altos executivos, ou o pessoal operacional.

Estratégia como um conjunto de esforços para a formulação e implementação das estratégias empresariais e nesse processo a formulação das estratégias, tradicionalmente, são abordadas como um processo de planejamento envolvendo, em geral, duas etapas: a de caráter quase permanente, que abrange a definição do negócio, bem como a explicitação da missão da organização e seus princípios orientadores; e a de caráter transitório, que implica a determinação de objetivos estratégicos e seus respectivos indicadores de acompanhamento, assim como a formulação das estratégias correspondentes para alcançá-los.

Nesse sentido estão seis características que de forma geral, são percebidas em diversas abordagens de gestão estratégica de pessoas. São elas: a) reconhecem a influência do ambiente externo sobre a dinâmica organizacional; b) reconhecem o impacto da competição entre organizações e as mudanças no mercado de trabalho; c) enfocam objetivos de longo prazo; d) valorizam o processo decisório e a escolha de alternativas; e) levam em consideração a relevância da totalidade dos indivíduos nas organizações e não somente os altos executivos, ou o pessoal operacional; f) buscam integrar as estratégias corporativas com as estratégias funcionais de cada área da empresa. (Silveira \& Miranda, 2011). 


\subsection{Modelo conceitual}

Se faz necessário para oferecer uma visão do objetivo a ser alcançado por meio desse estudo, não por meio de um texto mas sim por intermédio de uma figura ilustrativa intuitiva.

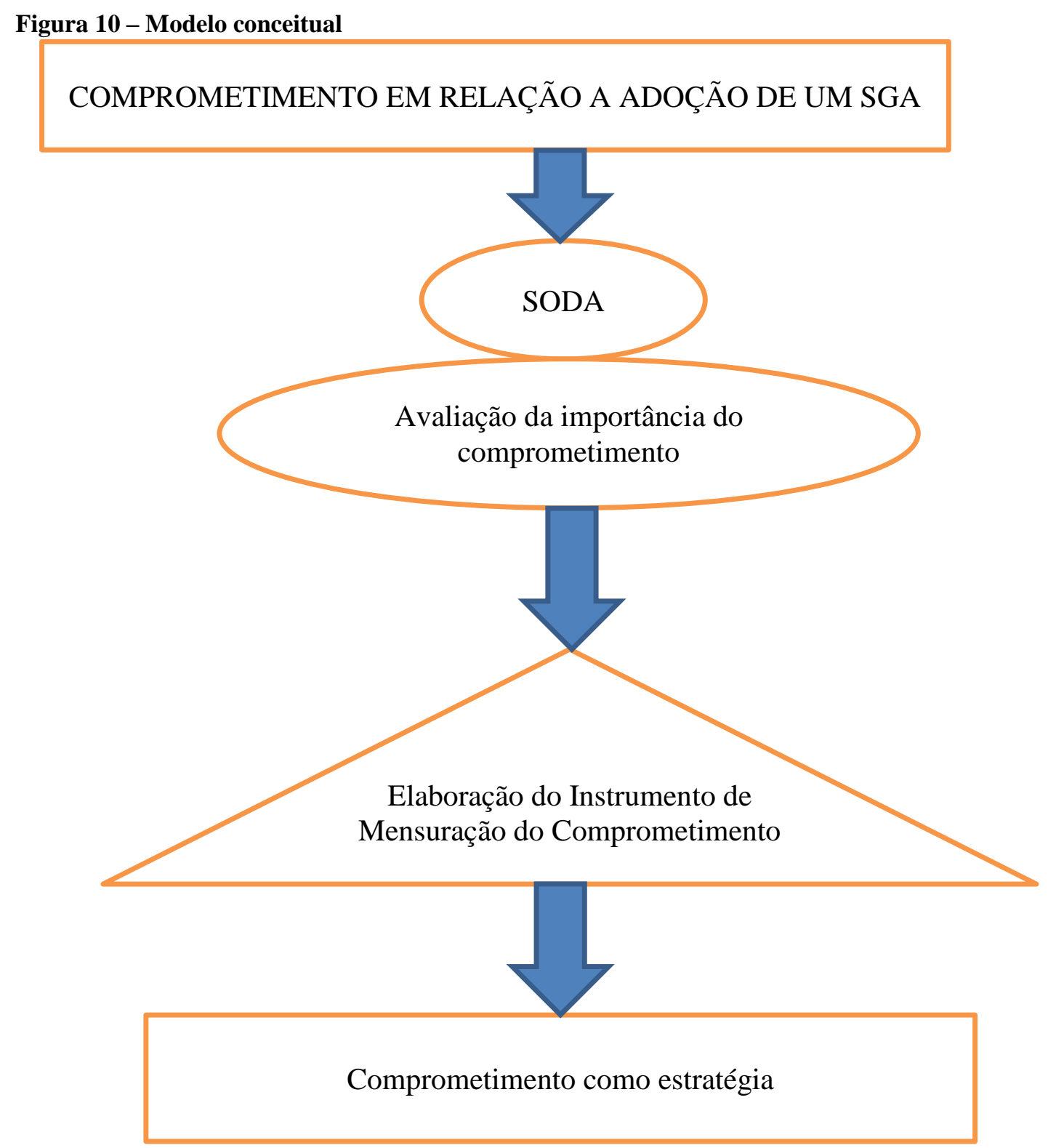

Fonte: Elaboração Própria 


\section{METODOLOGIA}

O capítulo inicia-se com uma breve explanação sobre a adoção do paradigma de pesquisa que foi adotado neste trabalho, o qual aborda: Amostra; Coleta dos Dados e Instrumento de Medida; Tratamento e Análise dos Dados; Limitação do Método; Discussão e Resultados.

Em relação à adoção da pesquisa qualitativa e não quantitativa, cabe a figura de linguagem citada por Cooper \& Schindler (2004), visto que o instrumento de mensuração aqui criado, será validado somente em estudos futuros como proposto no presente trabalho.

\footnotetext{
"Qualidade é o caráter ou a natureza essencial de alguma coisa; quantidade é a quantia. Qualidade é 'o que'; quantidade é 'quanto'. Qualitativo se refere ao significado, à definição, à analogia, ao modelo ou à metáfora caracterizando alguma coisa, enquanto quantitativo assume o significado e refere-se a uma medida dele..." (Cooper \& Schindler, 2002, p. 132).
}

A investigação iniciou-se por meio de uma pesquisa exploratória ${ }^{18}$ que adota o processo de pesquisa flexível e não estruturado, e buscou em seu primeiro momento diretrizes que conduziram a obtenção dos dados primários, que auxiliaram na formulação do instrumento de mensuração do comprometimento em relação a adoção de um Sistema de Gestão Ambiental, o qual utiliza-se de conceitos a serem descritos de forma a mensurar referido comportamento - "ineditismo do presente estudo".

Ainda sobre a fase exploratória há de se mencionar que conforme Collis \& Hussey, 2003 (apud Van Maanen, 1983, p.9) os métodos de pesquisa usados neste tipo de proposta é "uma série de técnicas interpretativas que procuram descrever, traduzir e, de outro modo, entender o significado e não a frequência de determinados fenômenos que acontecem com mais ou menos naturalidade no mundo social".

Quanto a proposta de validação do instrumento de mensuração aqui criado, esta deverá ser feita por meio de uma pesquisa quantitativa visto que quaisquer dos conceitos utilizados estão descritos de maneira que possibilitem sua mensuração. Conforme Malhotra (2006) a pesquisa conclusiva ${ }^{19}$ requer uma especificação clara em termos de quem, o que, quando, onde, por que e como. Como já citado, deverá ser por meio desse tipo de pesquisa a validação do instrumento aqui criado, o qual consiste na mensuração do comprometimento em relação a adoção de um SGA.

\footnotetext{
${ }^{18}$ Tipo de concepção de pesquisa que tem como principal objetivo ajudar a compreender a situação-problema enfrentada pelo pesquisador. (Malhotra, 2004, p. 98)

${ }^{19}$... "se baseia em amostras grandes e representativas e os dados obtidos estão sujeitos a uma análise quantitativa. Entretanto, deve-se observar que, da perspectiva da filosofia da ciência, nada pode ser provado em nada é conclusivo." (Malhotra, 2004, p. 100)
} 


\subsection{Pesquisa Qualitativa}

A pesquisa Qualitativa decorrente do paradigma Fenomenológico ou Interpretativo, como colocado por Collis \& Hussey (2005), é citada também em trabalhos científicos como Subjetiva e Humanista. Este tipo de pesquisa abrange a suposição metodológica que trata de padrões e teorias desenvolvidas para entendimento, sendo sua precisão e confiabilidade observadas por meio de verificação.

A coleta dos dados primários do presente estudo foi feita por intermédio de entrevista face a face, visto que o índice de resposta frequentemente aproxima-se de 70 a 80\%, Selltiz et. al. (2005). No caso da presente investigação o alcance foi de $100 \%$, ratificando o entendimento de que as pessoas estão dispostas e são capazes de cooperar num estudo onde tudo o que ela tem a fazer é falar. As pessoas normalmente apreciam falar com quem está interessada naquilo que pensam. Esse entendimento também é corroborado pelos autores Selltiz et al. (2005).

A entrevista foi realizada, sem reformulação das questões, mas sim se aproveitando da persistência em manter um tempo parcial, repetindo as perguntas quando do não entendimento por parte do entrevistado, dando a ele a oportunidade de refletir sobre suas respostas, por meio da receptividade a todas as respostas dadas e portando-se a entrevistadora como boa anotadora.

Referido procedimento segue o levantamento padrão de dados em estudos sociais, onde o entrevistador é comumente instruído apenas a repetir as questões e nunca explica-la, se resguardando dessa forma do viés de interferência nas respostas.

Ainda sobre a escolha da coleta de dados por meio de da entrevista face a face, foi observada também, a premissa de que os melhores entrevistadores não são os cientistas profissionais treinados e sim pessoas leigas, com boa habilidade de escrita e persistência no que se refere ao trabalhar em tempo parcial.

Esse entendimento foi assegurado por Maslow (2001), quando de sua pesquisa primeira sobre psicologia industrial/gerencial, disse ele: ... o principiante, geralmente, consegue ver coisas que escapam ao especialista. Tudo que é preciso é não sentir medo de cometer erros ou de parecer ingênuo. (Maslow, 2001, p. XXVIII)

Neste estudo referida premissa foi oportuna também, visto que a entrevistadora possui apenas conhecimento teórico de um Sistema de Gestão Ambiental, ou seja, não teve ainda a experiência de trabalhar em empresa que adota a Gestão Ambiental. 
Quanto ao método utilizado para análise dos dados, optou-se pelo "Mapeamento Cognitivo" 20 por tratar-se de um método de análise não-quantitativo. Visto que investigar o comprometimento em relação a adoção de um Sistema de Gestão Ambiental - SGA, é investigar a realidade a ser vivenciada em uma atividade desenvolvida com linguagem e ideias, e não com números e símbolos matemáticos.

A escolha deste método teve como base também a curiosidade primeira desta autora em relação a forma como é abordado o comprometimento organizacional, visto que em relação a um Sistema de Gestão Ambiental - SGA este comportamento tem destaque, como coloca Barbieri (2007).

"Qualquer SGA requer um conjunto de elementos comuns que independem da estrutura organizacional, do tamanho e do setor de atuação da empresa. Em primeiro lugar está o comprometimento com sua efetivação por parte da alta direção ou dos proprietários, se estes forem os dirigentes." (Barbieri, 2007, p. 153).

O mapeamento de cognição foi realizado por meio do Strategic Options Development and Analysis - SODA, que conforme Morita (2013) têm o rigor e formalismo derivado da teoria de construtos pessoais de Kelly (1955), o qual propõe o entendimento de como os seres humanos buscam significados para o seu mundo, procurando administrá-lo e controlá-lo.

Os construtos advindos do mapeamento cognitivo, expressaram as ideias e ações dos entrevistados concernente ao comprometimento em relação a adoção de um SGA. Estes construtos, que chegaram ao número máximo de 200, foram descritos utilizando as próprias palavras dos entrevistados, conferindo dessa forma a identidade entre o mapa e o entrevistado, mediante uma colaboração mais ativa, o que facilitou a exposição das possíveis soluções para as incertezas, complexidades e conflitos concernente a situação problemática ${ }^{21}$ neste estudo identificada.

Ainda sobre a escolha da ferramenta mapa cognitivo, se fez oportuna pois promove o registro de transcrições das entrevistas promovendo a análise dos dados obtidos considerando tanto a comunicação resultante como a estruturação de raciocínio dos entrevistados. A esse respeito encontra-se o entendimento de Dean (1958 apud Morita, 2013) em relação a Pesquisa Operacional (PO).

\footnotetext{
${ }^{20}$ Método de análise que pode ser usado para estruturar, analisar e entender o sentido de narrações escritas ou verbais de problemas. (Collis \& Hussey, 2005, p. 249)

${ }^{21}$ No sentido de problemas nos processos da Pesquisa Operacional (PO)
} 
Para o autor Pesquisa Operacional (PO) é a ciência, que tem por missão buscar as melhores decisões que uma empresa necessita, nas diversas áreas componentes de sua organização, e isso envolve a resolução de problemas, especialmente onde a interação entre componentes tenha papel significativo.

\subsubsection{Amostra}

A amostra aleatória composta por vinte e cinco Gerentes da Instituição pesquisada foi extraída da população de cinquenta e sete Gerentes. Referida população representa o total de Gerentes da Instituição Investigada. Hierarquicamente estes Gerentes estão entre a alta direção e o pessoal operacional.

Referida população é composta por servidores federais, regidos pelo Regime Jurídico Único (regime diferenciado do regime que conduz as contratações privadas), cuja idade média é cinquenta anos, em sua maioria com a possibilidade de aposentadoria a qualquer momento, considerando já terem adquirido esse direito.

Considerou ser uma amostragem probabilística, visto que os consultados, ou seja, os vinte e cinco Gerentes tiveram chance conhecida e igual de seleção. Gerentes que compõem a totalidade dos cargos de confiança de Instituição pesquisada nível 1 e 2.

Desses vinte e cinco Gerentes dez optaram por não participar da pesquisa. Os quinze Gerentes que aceitaram participar da investigação estão assim divididos: cinco da carreira de Pesquisador, cinco da carreira de Tecnologista, três da carreira de Analista e dois da carreira de Assistente.

Considerou-se a amostragem relevante para o presente estudo, pois a posição hierárquica, como já mencionado, dos referidos Gerentes encontra-se entre a alta administração e servidores a eles subordinados, podendo dessa forma informar interesses concernentes ao problema neste estudo proposto, tanto dos servidores posicionados em hierarquia superior, quanto dos posicionados em hierarquia inferior ao seu cargo.

Referida relevância corrobora com o entendimento de Estratégia no sentido abordado pela característica da Gestão Estratégica de Pessoas que considera a relevância da totalidade dos indivíduos nas organizações e não somente os altos executivos, ou o pessoal operacional. (Silveira \& Miranda, 2011).

Dado o interesse em participar das tomadas de decisão, pois fazem parte dos cargos de confiança da Instituição pesquisada, acreditou-se que referidos investigados forneceriam percepções verdadeiras concernentes a imperiosa necessidade de iniciativas para 
enfrentar os atuais e futuros desafios ambientais e sociais, quando da adoção de um SGA, e poderiam, conforme Nicollela et. al. 2004, constituir atributos desejáveis, não somente para a aceitação e compra de produtos e serviços, como também para a construção de uma imagem ambientalmente positiva junto à sociedade da Instituição da qual fazem parte.

Ressalta-se novamente que a Instituição investigada, vem passando nos últimos 20 vinte anos por sucateamento de recursos humanos, o número de servidores aposentados superou em muito o número de novos contratados por concurso público.

Nesse sentido, como já comentado, servidores remanescentes a serem envolvidos em uma gestão diferenciada deverão estar comprometidos com as profundas mudanças de paradigmas, pois embora não haja competividade em termos de lucratividade por tratar-se de uma Instituição Pública, existe sim a necessidade de se sobressair dentro de sua área de atuação, com o objetivo precípuo de angariar recursos financeiros e de ser reconhecida em sua competência como forma de se destacar no contexto técnico-científico nacional e internacional (pesquisa, produção e formação de recursos humanos), elementos imprescindíveis para o atendimento da missão de referida Instituição.

\subsubsection{Coleta dos Dados e Instrumento de Medida}

Os dados foram coletados por meio de entrevista face a face, realizada com os quinze Gerentes que compuseram a Amostra. As questões formalizadas fazem parte do Apêndice I denominado Coleta de Dados Primários.

Como já mencionado a entrevista foi realizada, sem reformulação das questões, mas sim se aproveitando da persistência em manter um tempo parcial, repetindo as perguntas quando do não entendimento por parte do entrevistado, dando a ele a oportunidade de refletir sobre suas respostas, por meio da receptividade a todas as resposta dadas e portando-se a entrevistadora como boa anotadora

Os dados foram coletados no período de maio 2015 à novembro de 2015, por meio de entrevistas individuais previamente agendadas, seguido por encontros grupais, realizadas no período de dezembro 2015 a março de 2016, sendo esses encontros realizados fora do expediente de trabalho, ou seja, antes do início da jornada diária de trabalho ou após o termino da jornada.

\subsubsection{Construção do Mapa Cognitivo}

Averiguar o comportamento dos servidores selecionados em relação as questões ambientais foi uma preocupação latente frente a possibilidade da adoção de uma SGA. Esta 
averiguação foi realizada com a aplicação da metodologia mapas SODA $^{22}$ cujo propósito foi descrever e analisar a situação tida como problemática, caracterizada por incertezas e complexidades relacionadas ao comprometimento, quando da adoção de uma gestão diferenciada, e entendida como não resolvida por modelos quantitativos formais.

O mapa cognitivo elaborado por intermédio da presente pesquisa obteve seus primeiros dados oriundos das respostas obtidas por meio das entrevistas face a face (questões constantes no Apêndice I), realizadas com os quinze Gerentes que compõem a amostra aqui analisada. Ou seja, a forma adotada para a construção do mapa cognitivo grupal deste estudo iniciou-se por meio de mapas cognitivos individuais com entrevistas particulares com cada membro. Optou-se por essa forma por entender ser esta a maneira que aumenta as chances de ocorrência do pensamento de equipe. Esse entendimento também é corroborado por Neck \& Manz (1994 apud Jardim, 2011).

Os construtos, conforme já citado, advindos do mapeamento cognitivo, expressaram as ideias e ações dos entrevistados concernente ao comprometimento em relação a adoção de um SGA. Estes construtos, que chegaram ao número máximo de 200, foram descritos utilizando as próprias palavras dos entrevistados, conferindo dessa forma a identidade entre o mapa e o entrevistado, mediante uma colaboração mais ativa, o que facilitou a exposição das possíveis soluções para as incertezas, complexidades e conflitos concernente a situação problemática ${ }^{23}$ neste estudo identificada.

A esse respeito acrescentam Neck \& Manz (1994 apud Jardim, 2011) que os sintomas: encorajamento de visões divergentes; abertura para a expressão de inquietações e ideias; preocupação sobre inquietações e ameaças; reconhecimento da singularidade dos membros; discussão de dúvidas coletivas são apresentados quando da opção dessa forma de construir mapas cognitivos, concluindo que esses padrões, ou oposições construtivas, conduzem a um ganho de efetividade do processo grupal e consequente aumento da qualidade do mapa cognitivo com iteração grupal. Parte do mapa cujo entendimento não possui interação grupal está exemplificado na Figura 11.

\footnotetext{
${ }^{22}$ Processo Strategic Options Development and Analysis - SODA encontra-se explicitado no Anexo I.

${ }^{23}$ No sentido de problemas nos processos da Pesquisa Operacional (PO)
} 


\section{Figura 11 - Parte do mapa cognitivo final sem interação grupal}

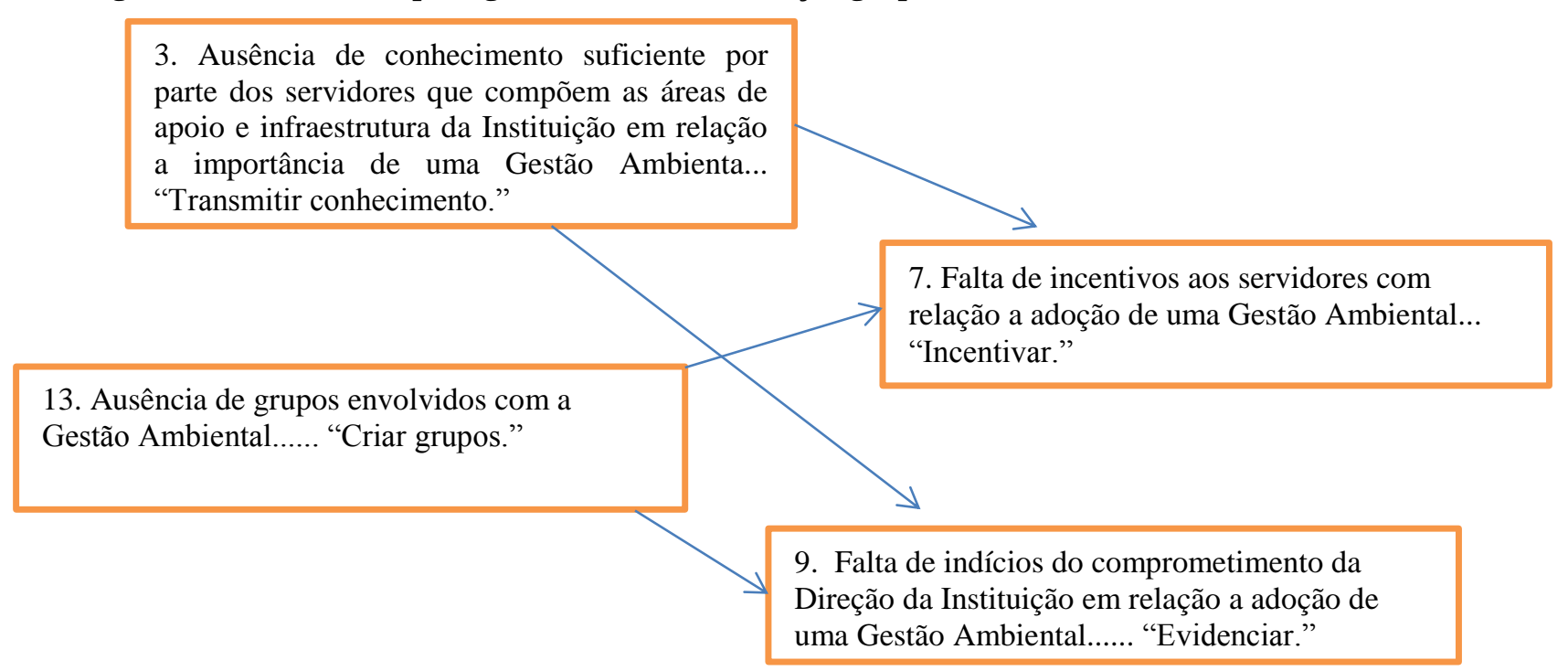

Fonte: adaptado do modelo de Curo et al, 2012, p. 15/16

As setas desse mapa (Figura 11) não tem "signo negativo"24. Alguns significados deste mapa que compõe o Apêndice II estão demonstrados no Quadro 1.

\section{Quadro 1 - Parte dos construtos do mapa cognitivo sem interação grupal ${ }^{25}$, e influências}

\begin{tabular}{|c|c|}
\hline Constructo - 3 & Constructo - 9 \\
\hline \multicolumn{2}{|c|}{$\begin{array}{l}\text { Ausência de conhecimento suficiente por parte dos servidores que compõem as áreas de apoio e } \\
\text { infraestrutura da Instituição em relação a importância de uma Gestão Ambiental influencia na } \\
\text { Falta de indícios do comprometimento da Direção da Instituição em relação a adoção de uma } \\
\text { Gestão Ambiental. }\end{array}$} \\
\hline Constructo - 3 & Constructo -7 \\
\hline \multicolumn{2}{|c|}{$\begin{array}{l}\text { Ausência de conhecimento suficiente por parte dos servidores que compõem as áreas de apoio e } \\
\text { infraestrutura da Instituição em relação a importância de uma Gestão Ambiental_influencia na } \\
\text { Falta de incentivos aos servidores com relação a adoção de uma Gestão Ambiental. }\end{array}$} \\
\hline Constructo - 13 & Constructo - 7 \\
\hline \multicolumn{2}{|c|}{$\begin{array}{l}\text { Ausência de grupos envolvidos com a gestão ambiental influencia na Falta de incentivos aos } \\
\text { servidores com relação a adoção de uma Gestão Ambiental. }\end{array}$} \\
\hline Constructo - 13 & Constructo - 9 \\
\hline
\end{tabular}

Fonte: adaptado do modelo de Curo et al, 2012, p. 14.

\footnotetext{
${ }^{24}$ As setas possuem signos negativos quando vincula a ideia de primeiro polo do primeiro constructo com a ideia de segundo polo do outro construto (Belderrain \& Castellini, 2012)

${ }^{25} \mathrm{O}$ mapa final sem interação grupal está representado no Apêndice II.
} 
Construído o mapa que compõe o Apêndice II, foram realizados quatro passos para a elaboração do mapa cognitivo com interação grupal, o qual compõe o Apêndice III. A construção desse mapa foi definida com a participação dos quinze investigados.

As reuniões se deram em numero de seis entre o investigador e cinco investigados, dada a falta de oportunidade para ocorrerem em grupo dos quinze, visto todos atuarem em áreas sobrecarregadas de atividades, cuja quantidade de colaboradores, segundo esses funcionários, está insuficiente.

$1^{\mathrm{o}}$ passo - definiu-se grupos compostos por cinco servidores que deveriam agir no processo decisório em relação às iniciativas para a adoção de um SGA. Esses servidores estavam diretamente envolvidos na situação problemática, e tinham conhecimentos específicos em áreas chaves ${ }^{26}$ :

$2^{\circ}$ passo - explicou-se sobre a necessidade da adoção de uma Gestão Ambiental e sua contribuição para a Instituição, a necessidade da participação de pessoas comprometidas com a organização para o alcance de tal meta e a necessidade de informações desses grupos e da importância de sua participação nessa pesquisa.

$3^{\circ}$ passo - apresentou-se os construtos constantes do Apêndice II e suas ligações solicitando que se manifestassem quanto às ligações realizadas, informando que tais ligações estariam abertas para acréscimos, redução ou modificações,

$4^{\circ}$ passo - colhidas as opiniões obtidas nas seis reuniões, foi criado o mapa cognitivo descrito no Apêndice III e novamente exposto para crivo dos quinze investigados. Criado um consenso sobre a situação foram identificados os $\operatorname{construtos}^{27}$ e suas ligações, e descritos os construtos apresentados no Quadro 2. Cabe salientar no entanto que os 25 construtos descritos na referida Quadro foram extraídos dos 200 construtos provenientes das 6 reuniões realizadas com os entrevistados.

\footnotetext{
${ }^{26}$ Área de Pesquisa, Área de Produção, Área de Aquisições, Área de Infraestrutura.

${ }^{27}$ Entendido por Georgiou, (2010 apud Belderrain \& Castellini, 2012, p. 8) como a dicotomia composta por dois polos, sendo que o segundo polo serve para esclarecer, contextualizar e refinar o contexto e entendimento do primeiro polo.
} 
Quadro 2 - Construtos identificados no mapa de interação grupal

\begin{tabular}{|c|c|c|}
\hline $\mathrm{N}^{\mathrm{o}}$ & Construto - Primeiro Polo & Construto - Segundo Polo \\
\hline 1 & $\begin{array}{l}\text { Falta identificar o nível de incorporação } \\
\text { dos valores da Instituição aos servidores. }\end{array}$ & $\begin{array}{l}\text { Adotar ações que esclareçam a } \\
\text { importância dos valores da Instituição } \\
\text { estarem incorporados nas rotinas dos } \\
\text { servidores. }\end{array}$ \\
\hline 2 & $\begin{array}{l}\text { Falta identificar ações que mantenham os } \\
\text { valores }{ }^{28} \text { da Instituição incorporados de } \\
\text { forma continua às atividades dos } \\
\text { servidores. }\end{array}$ & $\begin{array}{l}\text { Buscar a difusão da incorporação dos } \\
\text { valores da Instituição as atividades dos } \\
\text { servidores por meio de de estímulos que } \\
\text { conduza os próprios servidores a } \\
\text { contribuir. }\end{array}$ \\
\hline 3 & $\begin{array}{l}\text { usência de divulgação da importância } \\
\text { le um Sistema de Gestão Ambiental. }\end{array}$ & $\begin{array}{l}\text { Promover a divulgação da importância } \\
\text { de um Sistema de Gestão Ambiental. }\end{array}$ \\
\hline 4 & $\begin{array}{l}\text { Falta disseminar as possibilidades que } \\
\text { as políticas da Instituição já possuem em } \\
\text { relação a adoção de uma Gestão } \\
\text { Ambiental. }\end{array}$ & $\begin{array}{l}\text { Propagar as políticas da Instituição de } \\
\text { forma detalhada, ampla e contínua. }\end{array}$ \\
\hline 5 & $\begin{array}{l}\text { Falta identificar elementos que } \\
\text { favoreçam a implementação de um } \\
\text { Sistema de Gestão Ambiental bem } \\
\text { sucedido. }\end{array}$ & $\begin{array}{l}\text { Identificar elementos que conduzam a } \\
\text { implementação e manutenção de um } \\
\text { Sistema de Gestão Ambiental bem } \\
\text { sucedido. }\end{array}$ \\
\hline 6 & $\begin{array}{l}\text { Falta propagar o compromisso dos } \\
\text { Gestores da Instituição em relação a } \\
\text { adoção de um Sistema de Gestão } \\
\text { Ambiental. }\end{array}$ & $\begin{array}{l}\text { Divulgar o compromisso dos Gestores da } \\
\text { Instituição em relação a adoção de um } \\
\text { Sistema de Gestão Ambiental. }\end{array}$ \\
\hline 7 & $\begin{array}{l}\text { Falta promover esclarecimentos } \text { a } \\
\text { respeito da necessária adoção de um } \\
\text { Sistema de Gestão Ambiental na } \\
\text { Instituição.. }\end{array}$ & $\begin{array}{l}\text { Promover esclarecimentos da necessária } \\
\text { adoção de um Sistema de Gestão } \\
\text { Ambiental por meio de de treinamentos, } \\
\text { palestras, seminários, entre outros.. }\end{array}$ \\
\hline 8 & 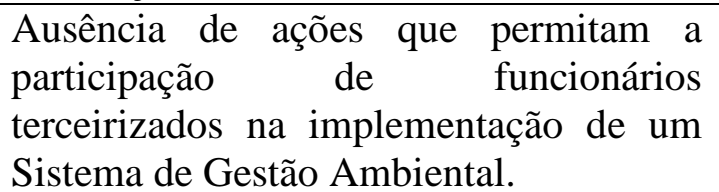 & $\begin{array}{l}\text { Adotar iniciativas que promovam a } \\
\text { participação de funcionários } \\
\text { terceirizados na implementação de um } \\
\text { Sistema de Gestão Ambiental. }\end{array}$ \\
\hline 9 & $\begin{array}{l}\text { Falta de conhecimento especifico para a } \\
\text { implementação de Sistema de Gestão } \\
\text { Ambiental. }\end{array}$ & $\begin{array}{l}\text { Contratar serviços de } \text { assessoria } \\
\text { especializada na condução de Sistema de } \\
\text { Gestão Ambiental. }\end{array}$ \\
\hline 10 & $\begin{array}{l}\text { Indisponibilidade de estrutura } \\
\text { adequada e de recursos humano e } \\
\text { financeiro para a implementação de } \\
\text { um Sistema de Gestão Ambiental. }\end{array}$ & $\begin{array}{l}\text { Angariar recursos junto a entidades } \\
\text { competentes, por meio de relatos da } \\
\text { necessidade de referida adoção e } \\
\text { implicâncias de seu não atendimento. }\end{array}$ \\
\hline 11 & $\begin{array}{l}\text { Falta conhecer empresas cuja Gestão } \\
\text { Ambiental esteja consolidada. }\end{array}$ & $\begin{array}{l}\text { Promover visitação a empresas onde a } \\
\text { Gestão Ambiental está consolidada. }\end{array}$ \\
\hline
\end{tabular}

\footnotetext{
${ }^{28}$ Representação de princípios, crenças e convicções que servem de guia para os comportamentos, atitudes e decisões de todas as pessoas que constituem a organização, ditando os caminhos que os comportamentos devem trilhar, guiando a vida da organização, visando atender seus objetivos, assim como as necessidades de todos aqueles que a constituem.
} 


\begin{tabular}{|c|c|c|}
\hline 12 & $\begin{array}{l}\text { Ausência de parceria com empresas que } \\
\text { possuem Sistema de Gestão Ambiental } \\
\text { bem sucedido. }\end{array}$ & $\begin{array}{l}\text { Propor parcerias com empresas e/ou } \\
\text { Instituições que possuam um Sistema de } \\
\text { Gestão Ambiental bem sucedido. }\end{array}$ \\
\hline 13 & $\begin{array}{l}\text { Falta difundir em linguagem apropriada } \\
\text { aos servidores da área meio e } \\
\text { funcionários terceirizados as pesquisas } \\
\text { desenvolvidas na Instituição. }\end{array}$ & $\begin{array}{l}\text { Promover a propagação das pesquisas } \\
\text { desenvolvidas pela Instituição. }\end{array}$ \\
\hline 14 & $\begin{array}{l}\text { Falta difundir aos servidores da área } \\
\text { meio e funcionários terceirizados os } \\
\text { produtos e serviços disponibilizados à } \\
\text { sociedade pela Instituição }\end{array}$ & $\begin{array}{l}\text { Propagar os produtos e serviços } \\
\text { disponibilizados pela Instituição.. }\end{array}$ \\
\hline 15 & $\begin{array}{l}\text { Falta conscientização da importância } \\
\text { em se trabalhar sob uma Gestão } \\
\text { Ambiental. }\end{array}$ & $\begin{array}{l}\text { Maximizar ações que favoreçam uma } \\
\text { continua educação ambiental. }\end{array}$ \\
\hline 16 & $\begin{array}{l}\text { Falta divulgar no âmbito da Instituição } \\
\text { como são desenvolvidas as atividades de } \\
\text { pesquisa em relação meio ambiente. }\end{array}$ & $\begin{array}{l}\text { Propagar a divulgação concernente ao } \\
\text { desenvolvimento das atividades de } \\
\text { pesquisa em relação ao meio ambiente. }\end{array}$ \\
\hline 17 & $\begin{array}{l}\text { Falta divulgar no âmbito da Instituição } \\
\text { como são desenvolvidas as atividades da } \\
\text { área meio em relação ao meio ambiente. }\end{array}$ & $\begin{array}{l}\text { Propagar a divulgação concernente ao } \\
\text { desenvolvimento das atividades da área } \\
\text { meio em relação ao meio ambiente. }\end{array}$ \\
\hline 18 & $\begin{array}{l}\text { Resistencia em relação a participação de } \\
\text { terceirizados nas ações que levam a } \\
\text { adoção de uma Gestão Ambiental. }\end{array}$ & $\begin{array}{l}\text { Propagar o permissivo legislativo quanto } \\
\text { a participação de funcionários } \\
\text { terceirizados nas ações concernentes a } \\
\text { adoção de uma Gestão Ambiental. }\end{array}$ \\
\hline 19 & $\begin{array}{l}\text { Falta tornar devidamente clara a } \\
\text { obrigatoriedade da alta administração em } \\
\text { relação ao direcionamento das ações } \\
\text { essenciais da Instituição no campo } \\
\text { social. }\end{array}$ & $\begin{array}{l}\text { Propagar a obrigatoriedade da alta } \\
\text { administração em relação } \\
\text { direcionamento das ações essenciais da } \\
\text { Instituição no campo social }\end{array}$ \\
\hline 20 & $\begin{array}{l}\text { Falta propagar o relacionamento da } \\
\text { Instituição com os clientes externos. }\end{array}$ & $\begin{array}{l}\text { Propagar o relacionamento da Instituição } \\
\text { com os clientes externos. }\end{array}$ \\
\hline 21 & $\begin{array}{l}\text { Falta conhecer e responder as } \\
\text { expectativas da sociedade concernentes } \\
\text { a maneira pela qual são desenvolvidas as } \\
\text { atividades da Instituição. }\end{array}$ & $\begin{array}{l}\text { Investigar as expectativas da sociedade } \\
\text { em relação à maneira pela qual são } \\
\text { desenvolvidas as atividades } \\
\text { Instituição. }\end{array}$ \\
\hline 22 & $\begin{array}{l}\text { Falta identificar se realmente os valores } \\
\text { da Instituição são aceitos pela maioria } \\
\text { de seus servidores. }\end{array}$ & $\begin{array}{l}\text { Investigar a aceitação dos servidores da } \\
\text { Instituição em relação aos valores por ela } \\
\text { propostos. }\end{array}$ \\
\hline 23 & $\begin{array}{l}\text { Ausência de legislação concernente às } \\
\text { aquisições governamentais sustentáveis. }\end{array}$ & $\begin{array}{l}\text { Participação em fóruns, congressos, } \\
\text { seminários que tratam do tema compras } \\
\text { governamentais sustentáveis. }\end{array}$ \\
\hline 24 & $\begin{array}{l}\text { Falta identificar os procedimentos da } \\
\text { Instituição quando da percepção de } \\
\text { indiferença dos servidores em relação a } \\
\text { mudanças. }\end{array}$ & $\begin{array}{l}\text { Divulgar mecanismos utilizados pela } \\
\text { Instituição quando da percepção da } \\
\text { indiferença dos servidores em relação a } \\
\text { mudanças. }\end{array}$ \\
\hline
\end{tabular}




\begin{tabular}{l|l|lrl}
\hline 25 & $\begin{array}{l}\text { Falta identificar o comportamento dos } \\
\text { servidores em relação à adoção de um } \\
\text { Sistema de Gestão Ambiental. }\end{array}$ & $\begin{array}{l}\text { Pesquisar mecanismos que conduzam a } \\
\text { identificação } \\
\text { comportamento. }\end{array}$ & de \\
\hline
\end{tabular}

Fonte: adaptado do modelo de Curo et al, 2012, p. 15/16.

\subsubsection{Tratamento e análise dos dados}

Para a análise do mapa cognitivo considerou-se a estruturação: Tails, Heads, Strategic Option, Implosions, Explosions e Dominants (Descritos no Anexo II). O mapa cognitivo final com interação grupal - Apêndice III formou-se em decorrência das respostas apresentadas nas entrevistas que compõe o Apêndice I. A figura 12 esboça o Mapa Cognitivo com interação grupal, que seguirá a análise de domínio de construto, que conforme Eden (2004 apud Morita, 2013), é similar a um nó inserido num dígrafo sinalizado, que tem conexões por meio de arcos orientados, abarcando os arcos direcionados que partem deste construto, bem como, os arcos que chegam a ele.

Apesar da existência de sistema computacional especificamente desenvolvido para a aplicação do mapeamento cognitivo, o que geralmente é utilizado para lidar com mapas de complexidade maior (muitos constructos) de forma mais flexível e rápida, tais como: Decision Explorer ${ }^{29}$ e CMAP2 ${ }^{30}$, optou-se pela análise manual, por considerar o total máximo de construtos atingidos, 200 construtos, não tão extenso e de média para baixa complexidade. Entendimento corroborado pelo número de apenas 25 construtos que constituíram o mapa cognitivo final com interação grupal.

\footnotetext{
${ }^{29}$ Software desenvolvido por Baxantia, 1996

${ }^{30}$ Software desenvolvido por Laukkanen, 1992,1998
} 
Figura 12 - Mapa cognitivo final com interação grupal expresso em grafos direcionados

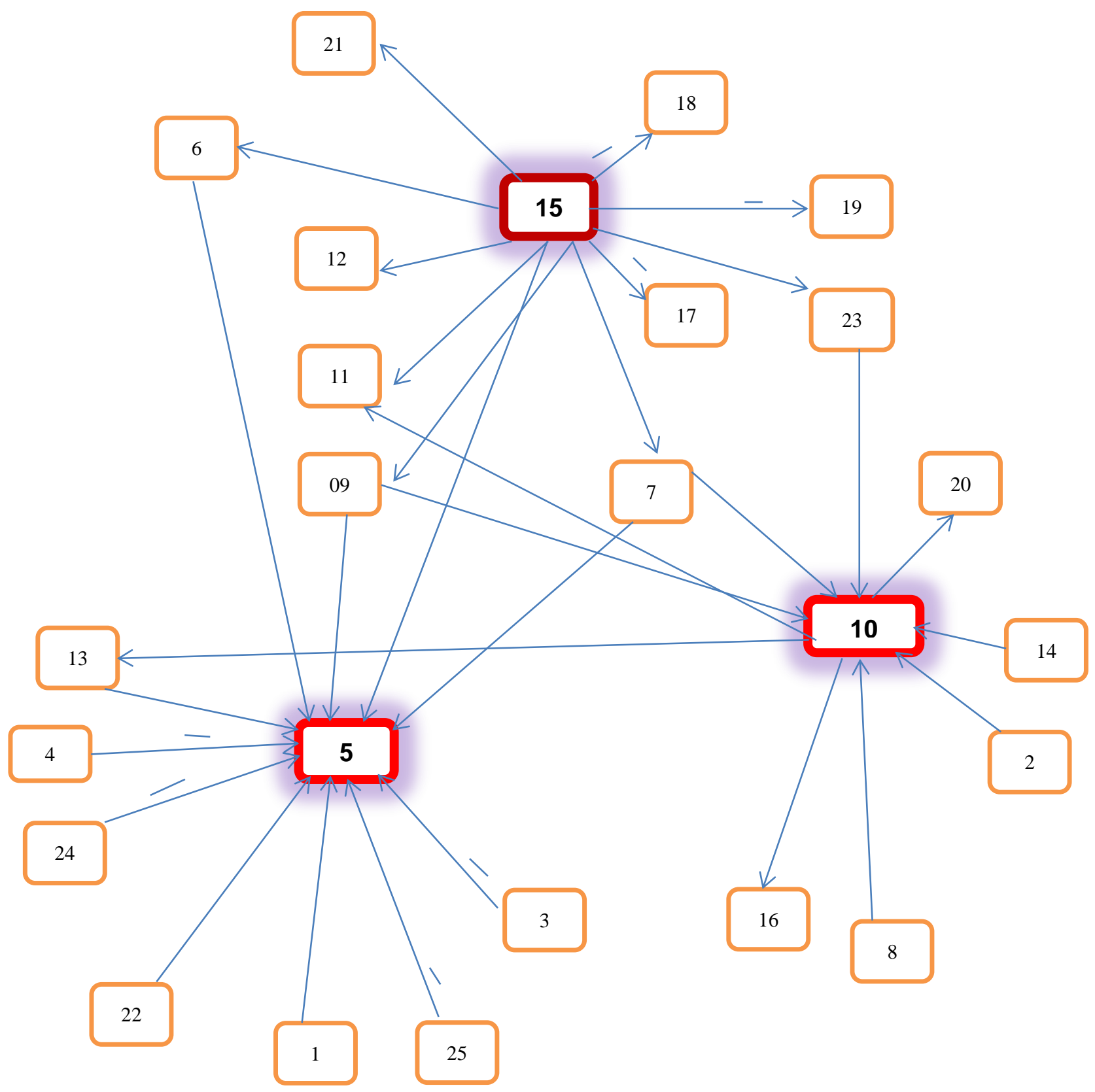

Fonte: adaptado do modelo de Curo et al, 2012

a) Identificação do construto tail - construtos que não recebem construtos - está demonstrado na Figura 13. 
Figura 13 - Identificação do construto tail no mapa cognitivo final com interação grupal

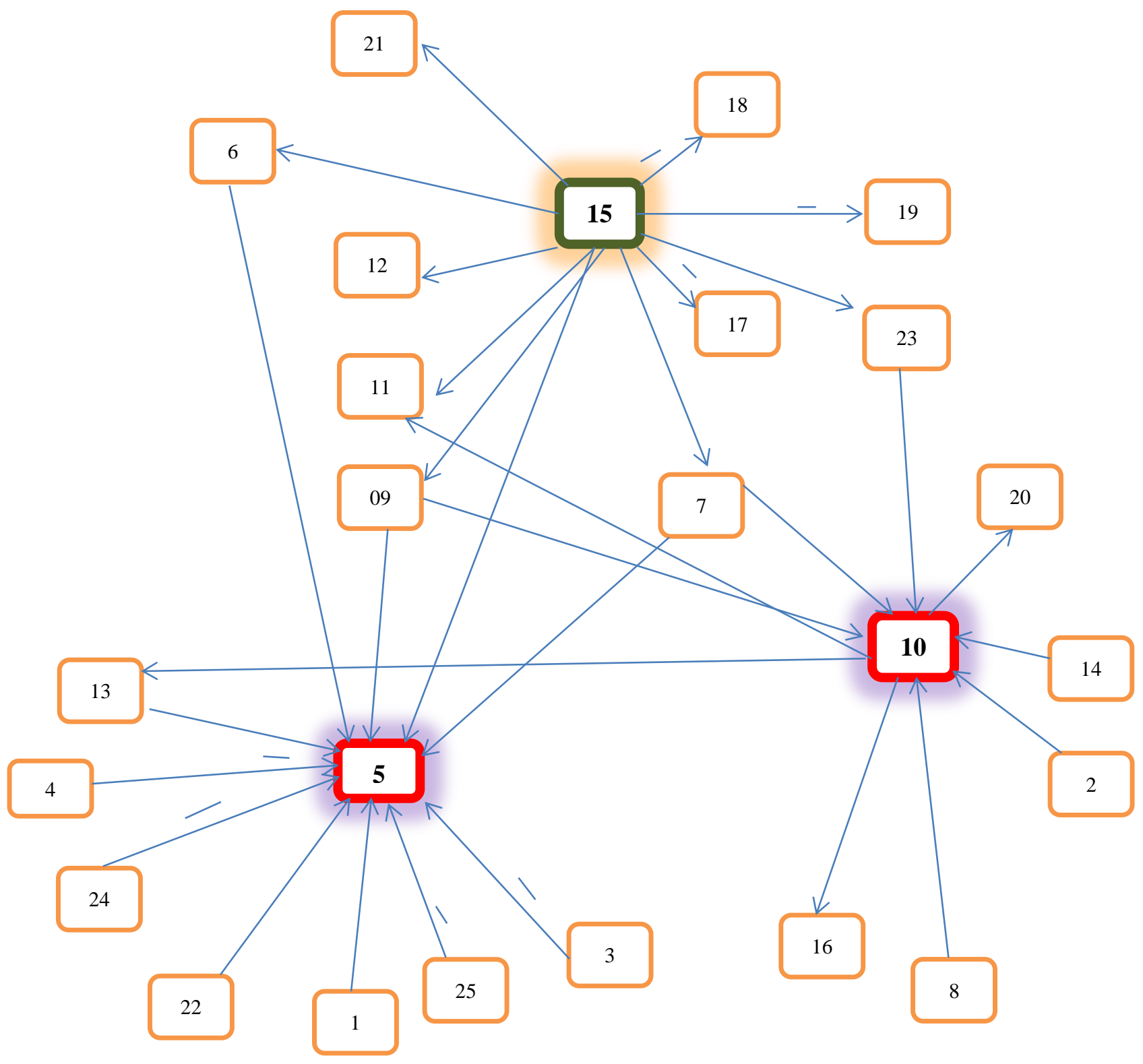

Fonte: adaptado do modelo de Curo et al, 2012

O construto fundamental "tail" do presente estudo, conhecido como causa primária do mapa final, o qual infere-se deve atingir a situação problemática é o de número 15, que tem no polo principal - Falta conscientização da importância em se trabalhar sob uma Gestão Ambiental e como polo secundário - Maximizar ações que favoreçam uma continua educação ambiental. Este construto como pode ser observado na Figura 13, tem 11 
arcos que incidem dele, o que infere-se também sua influência em outros construtos. A descrição dos construtos que incidem sobre este "tail” está demonstrada no Quadro 3.

Quadro 3 - Descrição dos construtos que incidem do construto 15, caracterizado neste estudo como "tail"

\begin{tabular}{|c|c|c|}
\hline Construto & Polo Principal & Polo Secundário \\
\hline 5 & $\begin{array}{l}\text { Falta identificar elementos que } \\
\text { favoreçam a implementação de um } \\
\text { Sistema de Gestão Ambiental bem } \\
\text { sucedido }\end{array}$ & $\begin{array}{l}\text { Identificar elementos que conduzam a } \\
\text { implementação e manutenção de um } \\
\text { Sistema de Gestão Ambiental bem } \\
\text { sucedido }\end{array}$ \\
\hline 6 & $\begin{array}{l}\text { Falta propagar o compromisso dos } \\
\text { Gestores da Instituição em relação a } \\
\text { adoção de um Sistema de Gestão } \\
\text { Ambiental. }\end{array}$ & $\begin{array}{l}\text { Divulgar o compromisso dos Gestores } \\
\text { da Instituição em relação a adoção } \\
\text { de um Sistema de Gestão Ambiental }\end{array}$ \\
\hline 7 & $\begin{array}{l}\text { Falta promover esclarecimentos a } \\
\text { respeito da necessária adoção de um } \\
\text { Sistema de Gestão Ambiental na } \\
\text { Instituição }\end{array}$ & $\begin{array}{l}\text { Promover esclarecimentos da } \\
\text { necessária adoção de um Sistema de } \\
\text { Gestão Ambiental por meio de de } \\
\text { treinamentos, palestras, seminários, } \\
\text { entre outros }\end{array}$ \\
\hline 9 & $\begin{array}{l}\text { Falta de conhecimento especifico para } \\
\text { a implementação de Sistema de } \\
\text { Gestão Ambiental }\end{array}$ & $\begin{array}{l}\text { Contratar serviços de assessoria } \\
\text { especializada na condução de Sistema } \\
\text { de Gestão Ambiental }\end{array}$ \\
\hline 11 & $\begin{array}{l}\text { Falta conhecer empresas cuja Gestão } \\
\text { Ambiental esteja consolidada }\end{array}$ & $\begin{array}{l}\text { Promover visitação a empresas onde a } \\
\text { Gestão Ambiental está consolidada }\end{array}$ \\
\hline 12 & $\begin{array}{l}\text { Ausência de parceria com empresas } \\
\text { que possuem Sistema de Gestão } \\
\text { Ambiental bem sucedido }\end{array}$ & $\begin{array}{l}\text { Propor parcerias com empresas e/ou } \\
\text { Instituições que possuam um Sistema } \\
\text { de Gestão Ambiental bem sucedido }\end{array}$ \\
\hline 17 & $\begin{array}{l}\text { Falta divulgar no âmbito da } \\
\text { Instituição como são desenvolvidas as } \\
\text { atividades da área meio em relação ao } \\
\text { meio ambiente }\end{array}$ & $\begin{array}{l}\text { Propagar a divulgação concernente ao } \\
\text { desenvolvimento das atividades da } \\
\text { área e meio em relação ao meio } \\
\text { ambiente }\end{array}$ \\
\hline 18 & $\begin{array}{l}\text { Resistencia em relação a participação } \\
\text { de terceirizados nas ações que levam } \\
\text { a adoção de uma Gestão Ambiental }\end{array}$ & $\begin{array}{l}\text { Propagar o permissivo legislativo } \\
\text { quanto a participação de funcionários } \\
\text { terceirizados nas ações concernentes a } \\
\text { adoção de uma Gestão Ambiental }\end{array}$ \\
\hline 19 & $\begin{array}{l}\text { Falta tornar devidamente clara a } \\
\text { obrigatoriedade da alta administração } \\
\text { em relação ao direcionamento das } \\
\text { ações essenciais da Instituição no } \\
\text { campo social }\end{array}$ & $\begin{array}{l}\text { Propagar a obrigatoriedade da alta } \\
\text { administração em relação a } \\
\text { direcionamento das ações essenciais } \\
\text { da Instituição no campo social }\end{array}$ \\
\hline 21 & $\begin{array}{llr}\text { Falta conhecer } & \text { e } & \text { responder as } \\
\text { expectativas } & \text { da } & \text { sociedade }\end{array}$ & $\begin{array}{l}\text { Investigar as expectativas da } \\
\text { sociedade em relação a maneira em }\end{array}$ \\
\hline
\end{tabular}




\begin{tabular}{|c|lr|l|}
\hline & $\begin{array}{l}\text { loncernentes a maneira em que são } \\
\text { desenvolvidas as atividades da } \\
\text { Instituição }\end{array}$ & $\begin{array}{l}\text { que são desenvolvidas as atividades } \\
\text { da Instituição }\end{array}$ \\
\hline 23 & $\begin{array}{l}\text { Ausência de legislação concernente às } \\
\text { aquisições governamentais } \\
\text { sustentáveis. }\end{array}$ & $\begin{array}{l}\text { Participação em fóruns, congressos, } \\
\text { seminários que tratam do tema } \\
\text { compras governamentais sustentáveis. }\end{array}$ \\
\hline
\end{tabular}

Fonte: adaptado do modelo de Curo et al, 2012, p. 15/16 
b) Identificação do construto head, construto que não fornece construtos, está demonstrado na figura 14.

Figura 14 - Identificação do construto head no mapa cognitivo final com interação grupal

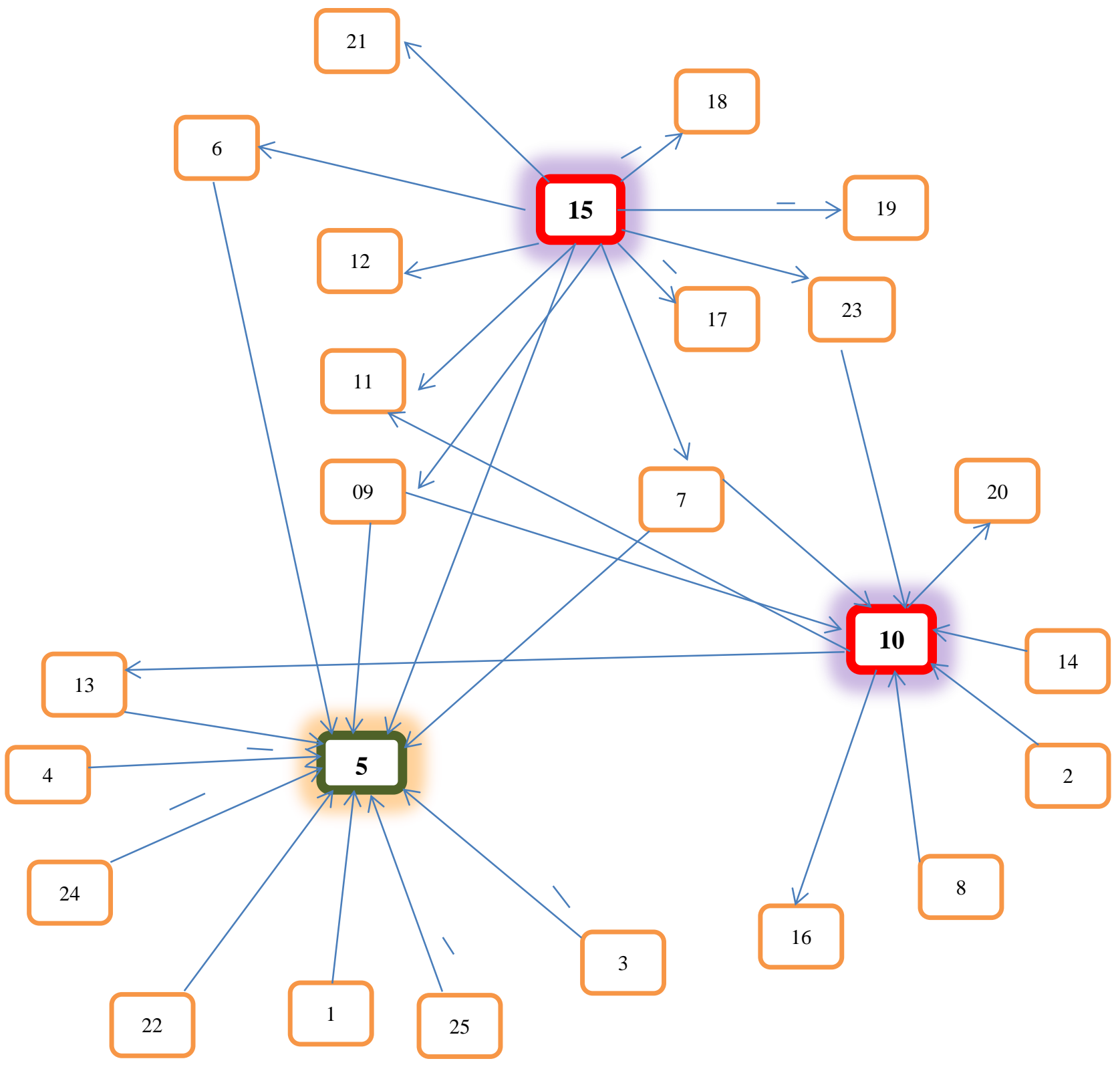

Fonte: adaptado do modelo de Curo et al, 2012

O construto "head" demonstrado na Figura 14, evidencia a necessidade de elemento que leve a implementação de um SGA bem sucedido, infere-se que esse construto atue como um foco/objetivo a ser alcançado. Sobre este construto incidem 11 outros 
construtos que refletem ser o construto de número 5, descrito no Quadro 4, o propósito da situação problemática nesta investigação apontado.

Quadro 4 - Descrição do construto head do mapa cognitivo com interação grupal

\begin{tabular}{|c|c|c|}
\hline Construto & Polo Principal & Polo Secundário \\
\hline 5 & $\begin{array}{l}\text { Falta identificar elementos que } \\
\text { favoreçam a implementação de } \\
\text { um Sistema de Gestão } \\
\text { Ambiental bem sucedido }\end{array}$ & $\begin{array}{l}\text { Identificar elementos que conduzam a } \\
\text { implementação e manutenção de um } \\
\text { Sistema de Gestão Ambiental bem } \\
\text { sucedido }\end{array}$ \\
\hline
\end{tabular}

Fonte: adaptado do modelo de Curo et al, 2012, p. 15/16

c) Identificação das Strategic options, construto vinculado ao head do mapa está, demonstrado na figura 15 .

Figura 15 - Identificação das Strategic options do mapa cognitivo final com interação grupal

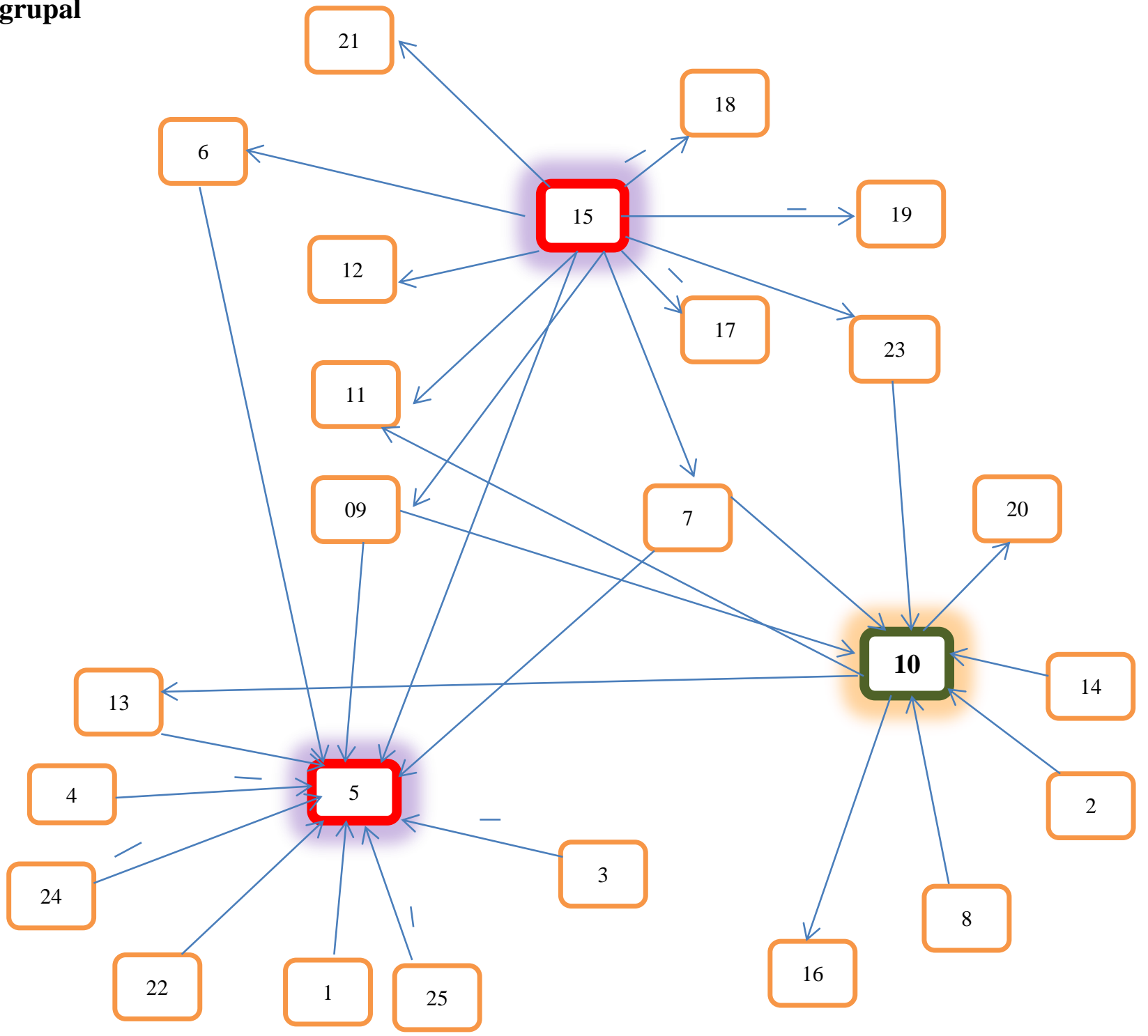

Fonte: adaptado do modelo de Curo et al, 2012 
O construto de número 10 "Strategic Option" demonstrado na Figura 15 - Polo Principal - Indisponibilidade de estrutura adequada e de recursos humano e financeiro para a implementação de um Sistema de Gestão Ambiental e Polo Secundário - Angariar recursos junto a entidades competentes, por meio de relatos da necessidade de referida adoção e implicâncias de seu não atendimento é o que indica as influências imediatas que antecedem o construto "head", o que infere-se a condução de construtos para o objetivo almejado.

No Quadro 5, estão descritos os construtos que incidem sobre o construto 10 e os que dele incidem.

Quadro 5 - Construtos que incidem sobre o construto Strategic Option e construtos que partem desse construto

\begin{tabular}{|c|c|c|}
\hline $\begin{array}{l}\text { Construto } \\
\text { Incidente } \\
\text { sobre }\end{array}$ & Polo Primário & Polo Secundário \\
\hline 2 & $\begin{array}{l}\text { Falta identificar ações que } \\
\text { mantenham os valores }{ }^{31} \mathrm{da} \\
\text { Instituição incorporados de forma } \\
\text { continua às atividades dos } \\
\text { servidores }\end{array}$ & $\begin{array}{l}\text { Buscar a difusão da incorporação dos } \\
\text { valores da Instituição as atividades dos } \\
\text { servidores por meio de estímulos que } \\
\text { conduza os próprios servidores a } \\
\text { contribuir }\end{array}$ \\
\hline 7 & $\begin{array}{l}\text { Falta promover esclarecimentos a } \\
\text { respeito da necessária adoção de } \\
\text { um Sistema de Gestão Ambiental } \\
\text { na Instituição }\end{array}$ & $\begin{array}{l}\text { Promover esclarecimentos da necessária } \\
\text { adoção de um Sistema de Gestão } \\
\text { Ambiental por meio de treinamentos, } \\
\text { palestras, seminários, entre outros }\end{array}$ \\
\hline 8 & $\begin{array}{l}\text { Ausência de ações que permitam a } \\
\text { participação de funcionários } \\
\text { terceirizados na implementação de } \\
\text { um Sistema de Gestão Ambiental }\end{array}$ & $\begin{array}{l}\text { Adotar iniciativas que promovam a } \\
\text { participação de funcionários } \\
\text { terceirizados na implementação de um } \\
\text { Sistema de Gestão Ambiental }\end{array}$ \\
\hline 9 & $\begin{array}{l}\text { Falta de conhecimento especifico } \\
\text { para a implementação de Sistema } \\
\text { de Gestão Ambiental }\end{array}$ & $\begin{array}{l}\text { Contratar serviços de } \text { assessoria } \\
\text { especializada na condução de Sistema de } \\
\text { Gestão Ambiental }\end{array}$ \\
\hline 14 & $\begin{array}{l}\text { Falta difundir aos servidores da } \\
\text { área meio e funcionários } \\
\text { terceirizados os produtos e } \\
\text { serviços disponibilizados à } \\
\text { sociedade pela Instituição }\end{array}$ & $\begin{array}{l}\text { Propagar os produtos e serviços } \\
\text { disponibilizados pela Instituição.. }\end{array}$ \\
\hline 23 & $\begin{array}{l}\text { Ausência de legislação } \\
\text { concernente às aquisições } \\
\text { governamentais sustentáveis }\end{array}$ & $\begin{array}{l}\text { Participação em fóruns, congressos, } \\
\text { seminários que tratam do tema compras } \\
\text { governamentais sustentáveis }\end{array}$ \\
\hline
\end{tabular}

${ }^{31}$ Representação de princípios, crenças e convicções que servem de guia para os comportamentos, atitudes e decisões de todas as pessoas que constituem a organização, ditando os caminhos que os comportamentos devem trilhar, guiando a vida da organização, visando atender seus objetivos, assim como as necessidades de todos aqueles que a constituem. 


\begin{tabular}{|c|l|l|}
\hline $\begin{array}{c}\text { Construto } \\
\text { incidente de }\end{array}$ & \multicolumn{1}{|c|}{ Polo Primário } & \multicolumn{1}{|c|}{ Polo Secundário } \\
\hline 11 & $\begin{array}{l}\text { Falta conhecer empresas cuja } \\
\text { Gestão Ambiental esteja } \\
\text { consolidada. }\end{array}$ & $\begin{array}{l}\text { Promover visitação a empresas onde } \\
\text { a Gestão Ambiental está consolidada }\end{array}$ \\
\hline 13 & $\begin{array}{l}\text { Falta difundir em linguagem } \\
\text { apropriada aos servidores da área } \\
\text { meio e funcionários terceirizados } \\
\text { as pesquisas desenvolvidas na } \\
\text { Instituição }\end{array}$ & $\begin{array}{l}\text { Promover a propagação das } \\
\text { pesquisas desenvolvidas pela } \\
\text { Instituição }\end{array}$ \\
\hline 16 & $\begin{array}{l}\text { Falta divulgar no âmbito da } \\
\text { Instituição como são } \\
\text { desenvolvidas as atividades de } \\
\text { pesquisa em relação meio } \\
\text { ambiente }\end{array}$ & $\begin{array}{l}\text { Propagar a divulgação concernente } \\
\text { ao desenvolvimento das atividades } \\
\text { de pesquisa em relação ao meio } \\
\text { ambiente }\end{array}$ \\
\hline 20 & $\begin{array}{l}\text { Falta propagar o relacionamento } \\
\text { da Instituição com os clientes } \\
\text { externos }\end{array}$ & $\begin{array}{l}\text { Propagar o relacionamento da } \\
\text { Instituição com os clientes externos }\end{array}$ \\
\hline
\end{tabular}

Fonte: adaptado do modelo de Curo et al, 2012, p. 15/16

d) Identificação dos Implosions - Explosions demonstrados na Tabela1, refletem os tipos de construtos originários da presente pesquisa.

Tabela 1 - Implosions / Explosions

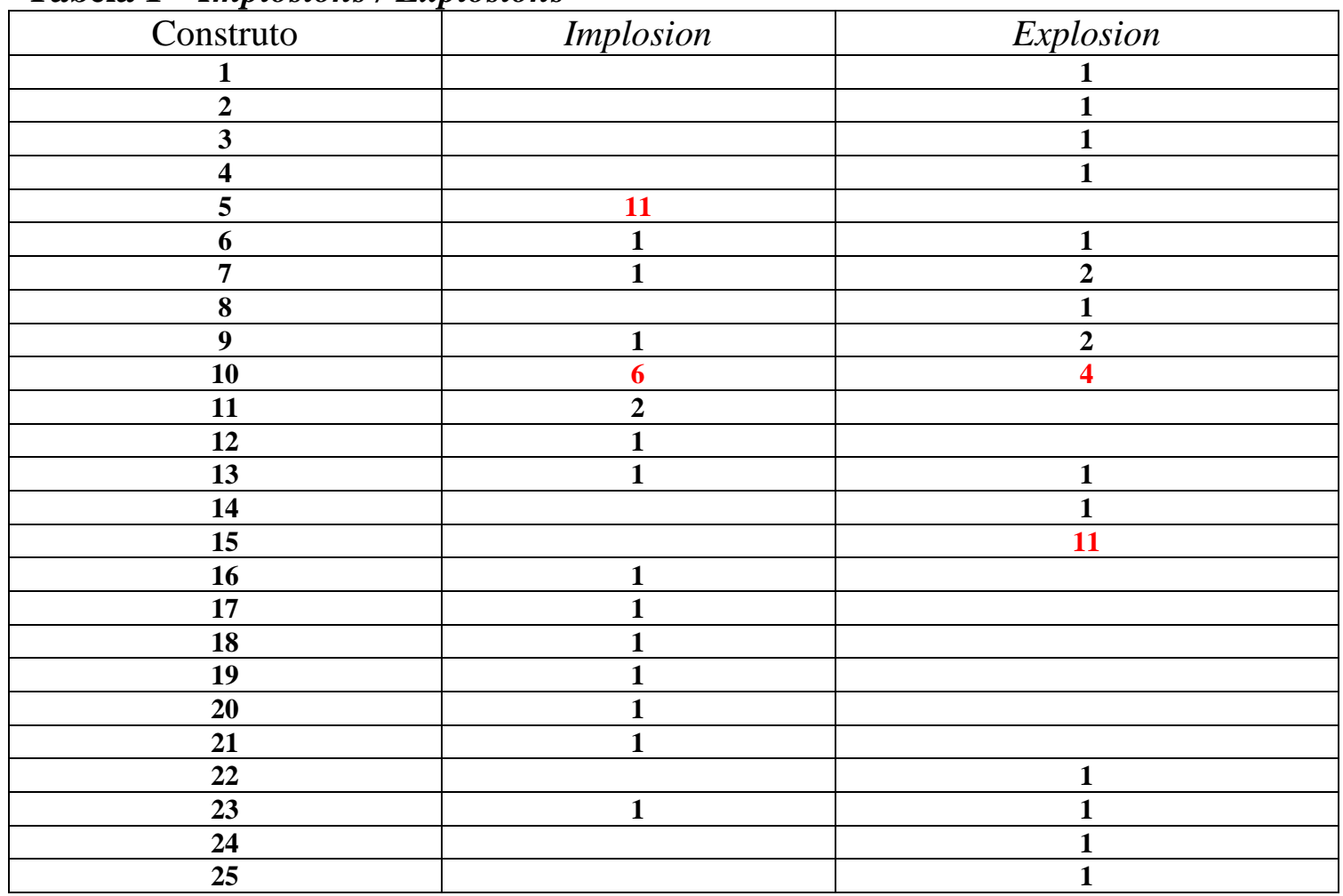

Fonte: Elaboração própria 
No presente estudo o implosion 32 foi identificado sobre o construto "head" 5 (Polo Principal - Falta identificar elementos que favoreçam a implementação de um Sistema de Gestão Ambiental bem sucedido; e Polo Secundário - Identificar elementos que conduza a implementação e manutenção de um Sistema de Gestão Ambiental bem sucedido). Constatando ter sido referido construto influenciado diretamente por 11 construtos.

O construto de numero 15 "tail" cujo Polo principal é: Falta conscientização da importância em se trabalhar sob uma Gestão Ambiental e o Polo Secundário Maximizar ações que favoreçam uma continua educação ambiental, teve sobre si o explosion $^{33}$, demonstrando sua influência sobre 11 construtos.

Quanto ao construto de número 10 "Strategic Option" (Polo Principal Indisponibilidade de estrutura adequada e de recursos humano e financeiro para a implementação de um Sistema de Gestão Ambiental e Polo Secundário Angariar recursos junto a entidades competentes, por meio de relatos da necessidade de referida adoção e implicâncias de seu não atendimento), teve sobre si a influência de 6 construtos e influenciou 4 construtos, inferindo ser este o construto que canaliza o fluxo de construtos para o objetivo "head".

A análise de domínio de construto apontou os três construtos (de números 5 - 10 e 15) que sofreram e exerceram influência no âmbito do mapa cognitivo aqui investigado, permitindo inferir a premente necessidade do conhecimento de elementos que conduzam a implementação de SGA bem sucedido.

\subsubsection{Limitação do Método}

Embora o mapeamento cognitivo SODA apresente resultados congruentes, estudos como de Morita (2011) e Arêas (2010), apontam que as respostas procuradas por meio do SODA em conjunto com a aplicação de outros Métodos de Estruturação de Problemas, SCA (Strategic Choice Approach), SSM (Soft System Methodology), entre outros, intensificam os resultados. No entanto o presente estudo utilizou-se apenas do Strategic Options Development and Analysis - SODA.

\footnotetext{
32 Número maior de arcos que incidem sobre o construto.

${ }^{33}$ Número maior de arcos que incidem do construto.
} 


\section{DISCUSSÃO E RESULTADOS}

Quando da adoção de um Sistema de Gestão Ambiental - SGA, se faz necessário além da importância de toda sua proposta, ou seja, a de se gerir adotando-se procedimentos voltados para a preservação do meio ambiente, ter disponível recursos orçamentários e financeiros para referida aquisição, tanto para empresas públicas como para privadas.

No caso da Instituição Pública investigada, os recursos são disponibilizados pelo Governo Federal, que para isto, exige por parte dos Gestores o envio de projetos contendo a justificativa da necessidade da contratação, dispondo sobre a motivação da contratação, os benefícios diretos e indiretos que dela resultarão, bem como, a obediência a toda legislação pertinente.

O Gestor deve também atentar para a força de trabalhado a ser envolvida nas tarefas oriundas de referido projeto. Esta força de trabalho deverá estar comprometida com as propostas de mencionado plano.

A esse respeito segue exemplificado, manifestação do Tribunal de Contas da União datada do ano 2015. Referida manifestação adverte uma Fundação Federal que utiliza recursos da União, a doravante conciliar suas solicitações de dotações orçamentárias com a sua efetiva capacidade Técnica, operacional e administrativa quando da utilização de referidos recursos.

De fato, os projetos meritórios e de grande alcance social pretendidos pela alta administração dessa Fundação, não considerou investigar o comprometimento dos servidores envolvidos nas lides administrativas para ultimar os procedimentos necessários a sua formalização.

Como resultado os recursos disponibilizados pela União não foram utilizados gerando como prejuízo maior o não usufruto dos benefícios oriundos desses projetos pela população alvo.

Com o intuito de responder a questão levantada no presente estudo, e atenta a manifestação exemplificado, observou-se com a presente investigação a possibilidade, embora a longo prazo, da adoção de um Sistema de Gestão Ambiental - SGA pela Instituição investigada.

Existiu também o entendimento de que a grande maioria dos servidores responsáveis pelo desenvolvimento das atividades fim da Instituição, ainda não trabalham com a gestão ambiental de forma mais ampla. A parte ambiental por eles trabalhada restringe- 
se a sua atividade específica, igualando-se nesse sentido aos economistas que ainda desempenham suas atividades, considerando as teorias econômicas consolidadas, não incluindo em suas práticas a necessidade da considerar também a gestão ambiental tão relevante no presente período da humanidade.

Os dados demonstraram também haver a preocupação em relação a adoção de uma gestão ambiental, no entanto não se evidencia o conhecimento necessário para referida ação e nem a disponibilidade por parte da Instituição de estrutura adequada e recurso financeiro disponível. Este entendimento está explicitado no construto de número 10 "strategic option”, do mapa cognitivo com interação grupal, onde seu Polo Principal identifica: "Indisponibilidade de estrutura adequada e de recursos humano e financeiro para a implementação de um Sistema de Gestão Ambiental” - Polo Secundário - "Angariar recursos junto a entidades competentes, por meio de relatos da necessidade de referida adoção e implicâncias de seu não atendimento.”

Infere-se com esta colocação, haver por parte da amostra investigada a preocupação concernente a força de trabalho a ser envolvida na gestão a ser adotada.

Constatou-se também que o SGA não está sendo visto como uma prioridade pela Instituição, revelando neste sentido não haver ainda o comprometimento da alta administração com relação a tal gestão. No entanto, percebe-se haver ciência de que a atividade principal da Instituição, seu ramo de pesquisa, já possui por si só um forte viés ambiental, cujos impactos constam em seus planos de contingências no sentido de serem minimizados.

Conforme construto de número 14 do mapa cognitivo com interação grupal percebe-se a necessidade de uma divulgação maior dos resultados oriundos destas atividades. Polo principal "falta difundir aos servidores da área meio e funcionários terceirizados os produtos e serviços disponibilizados a sociedade à sociedade pela Instituição - Polo Secundário "Propagar os produtos e serviços disponibilizados pela Instituição.

Infere-se, mediante estas constatações, a necessidade de conhecer o comprometimento organizacional dos funcionários a serem envolvidos, na adoção de um Sistema de Gestão Ambiental - SGA, visto que o sucesso de sua implementação se faz também por meio do comprometimento dos funcionários a serem envolvidos nos objetivos e valores por ele proposto, bem como pela crença em sua indispensabilidade.

Este entendimento foi confirmado no construto de número 5 "head" o qual reconhece a necessária identificação de elementos que conduzam a implementação e manutenção de um SGA bem sucedida, e cuja causa primária foi o reconhecimento da falta 
de conscientização da importância em se trabalhar sob uma Gestão Ambiental, seguida pela necessidade de se maximizar ações que favoreçam uma continua educação ambiental.

O resultado da análise do mapa cognitivo levou a criação do modelo de mensuração do comprometimento, descrito no Apêndice IV, o qual procura por intermédio de seus apontamentos mensurar referido comportamento em relação a adoção de um Sistema de Gestão Ambiental - SGA.

Referido modelo considerou apenas as dimensões Afetiva e Normativa.

Afetiva dado o entendimento da disposição do indivíduo em exercer um esforço considerável em beneficio ao pleito requerido (a implementação de um SGA bem sucedido), bem como uma crença e aceitação dos objetivos e valores por ele proposto e um desejo de se manter atuante em suas propostas.

Normativa dado o entendimento do indivíduo em aceitar os valores e objetivos propostos pelo pleito (a implementação de um SGA bem sucedido), indivíduos comprometidos dentro de um enfoque normativo exibem determinados comportamentos porque acreditam que é certo e moral fazê-lo.

Quanto a não opção pela dimensão Instrumental no modelo aqui sugerido, revelou a presente pesquisa não se enquadrar na obtenção do objetivo proposto neste estudo, por não conferir que trocas laterais, características da referida dimensão, se enquadra no pleito (implementação de um SGA bem sucedido).

Neste estudo o comprometimento em relação a adoção de um SGA, não se define por trocas, mas sim pela aceitação dos objetivos e valores por ele proposto e pela crença de ser o correto a ser feito.

Como já mencionado é certo que não há uma única forma de gerenciar. A organização por sua dinâmica estará sempre a procura de soluções diferentes para lidar com a complexidade de problemas advindos de sua própria atuação. Nesse sentido o modelo aqui proposto, poderá ser utilizado também quando da adoção de outras formas de gestão, pois propicia a identificação antecipada de situações relevantes e preocupações inerentes ao comprometimento.

Contudo ressalta-se que para referida aplicabilidade se faz necessária sua adequação aos parâmetros essências da gestão escolhida. 


\section{CONCLUSÕES}

Esta tese, utilizando-se do mapa cognitivo Strategic Options Development and Analysis - SODA, se propôs a atender o objetivo nela especificado, ou seja, avaliar a importância do comprometimento organizacional para a implementação de um Sistema de Gestão Ambiental - SGA utilizando a amostra aleatória composta por quinze Gerentes de um Instituto Federal de Pesquisa, bem como elaborar um modelo de mensuração de referido comportamento em relação ao SGA.

O método de estruturação de problemas - Problem Structuring Methods (PSMs) - mapa cognitivo SODA utilizado possibilitou investigar, as possíveis incertezas, complexidades e conflitos, voltados para o elemento comprometimento, provenientes da adoção de uma gestão ambiental, por intermédio da implementação de um Sistema de Gestão Ambiental - SGA.

O resultado da análise do mapa cognitivo demonstrou a importância do comprometimento organizacional quando da intenção de se adotar um Sistema de Gestão Ambiental. Diferentemente do entendimento de Barbieri (2007), o presente estudo coloca a importância desse comportamento não somente por parte da alta direção, mas também por parte de toda a equipe a ser envolvida nas atividades concernentes a tal sistema.

Permitiu também a construção de um modelo de mensuração do comprometimento em relação ao Sistema de Gestão Ambiental - SGA. Modelo este descrito no Apêndice IV desta Tese.

As organizações por suas dinâmicas estarão sempre a procura de soluções diferentes para lidar com a complexidade de problemas advindos de suas próprias atuações. Dentro desta complexidade, conforme observado na presente investigação, um fator que nunca pode ser esquecido é o conhecimento do comprometimento dos funcionários a serem envolvidos nas atuações propostas.

Neste sentido o modelo aqui proposto, poderá ser utilizado quando da adoção de um Sistema de Gestão Ambiental - SGA, pois propiciará a identificação antecipada de situações relevantes concernente a referido comportamento por parte da força de trabalho a ser envolvida na gestão pretendida, contribuindo para o alcance dos objetivos e politicas a ela inerentes.

Acrescenta-se ainda a esse entendimento, os custos associados quando da adoção de uma gestão distinta. A gestão neste estudo especificada requer a aquisição de um Sistema 
de Gestão Ambiental, para a partir dele instituir a gestão ambiental. Esses custos, por tratarse de uma Instituição Pública, são cobertos por verbas públicas que tem a obrigatoriedade por parte de seus Gestores da prestação de contas aos órgãos de controle do Poder Público.

Infere-se também que conhecer antecipadamente o grau de comprometimento dos servidores a serem envolvidos evitaria que a contratação sofresse os percalços da situação fática exemplificada nesta tese, onde o Poder Público não alcançou os resultados esperados por não considerar a vertente comprometimento, ensejando grande frustração na comunidade e na própria missão da Fundação aqui mencionada.

O modelo aqui proposto, não foi validado visto o prazo exigido para tal procedimento. Sugere-se no entanto, que seja empregado em estudos futuros como estratégia quando da intenção de se trabalhar obedecendo as diretrizes de uma gestão ambiental. Sugerese também que referida validação seja efetivada por meio de estudos longitudinais ${ }^{34}$.

\footnotetext{
${ }^{34}$ Estudos longitudinais usam uma amostra para descrever elementos administrativos. Em vez de descrevê-los em um único ponto no tempo, os dados longitudinais descrevem eventos ao longo do tempo. Os dados longitudinais permitem mapear elementos administrativos de modo que se possam observar as tendências. (Hair et al. , 1005, p. 88)
} 


\section{REFERÊNCIAS BIBLIOGRÁFICAS}

ALLEN, N. J. \& MEYER, J. P. The measurement and antecedents of affective, continuance and normative commitment to the organization. Jornal of Occupational Psychology. V. 63, P. 1-18, 1990.

AQUINO, Afonso R.; ABREU, Igor \& ALMEIDA, Josimar. R. Análise de Sistema de Gestão Ambiental. São Paulo: Thex, 2008.

ASSOCIAÇÃO BRASILEIRA DE NORMAS TÉCNICAS. NBR 6023: informação e documentação: referências - elaboração. Rio de Janeiro: ABNT, 2002.

ASSOCIAÇÃO BRASILEIRA DE NORMAS TÉCNICAS. NBR 10520: informação e documentação: citações em documentos: apresentação. Rio de Janeiro, 2002.

ASSOCIAÇÃO BRASILEIRA DE NORMAS TÉCNICAS. NBR 6024: informação e documentação: numeração progressiva das seções de um documento escrito: apresentação. Rio de Janeiro, 2003.

BANDEIRA, Mariana L. Investigando o impacto das Políticas de Recursos Humanos no Comprometimento Organizacional em uma empresa de serviços do setor público. Dissertação de Mestrado-Faculdade de Ciências Econômicas da UFMG, Belo Horizonte, 1999.

BANDEIRA, M. L.; MARQUES, A. L. \& VEIGA, R. T. A ECT na trilha da modernidade: políticas de recursos humanos influenciando múltiplos comprometimentos. In. EnANPAD 99, Foz do Iguaçu, Anais do $23^{\circ}$ ENCONTRO da ANPAD, 1999.

BARBIERI, José Carlos. Gestão ambiental empresarial. 2. ed. São Paulo: Saraiva, 2007.

BARBIERI, José Carlos \& SIMANTOB, Moysés Alberto. Organizações Inovadoras Sustentáveis. São Paulo: Atlas, 2007.

BARBIEIRI, José Carlos \& CAJAZEIRA J. Emanuel Reis. Responsabilidade Social Empresarial e Empresa Sustentável - da teoria à prática. São Paulo: Saraiva, 2009.

BASTOS, Antonio V. Bittencourt. BASTOS, Antonio V. Bittencourt. Os vínculos indivíduoorganização: uma revisão da pesquisa sobre comprometimento organizacional. In: ENAMPAD 92, Canela, Anais do 16² Encontro da ANPAD, v.6, 290-304, 1992.

BASTOS, Antonio V. Bittencourt. Comprometimento organizacional: um balanço dos resultados e desafios que cercam essa tradição de pesquisa. Revista de Administração de Empresas. 33(3), 52-64, 1993.

BASTOS, Antonio V. Bittencourt. Comprometimento no Trabalho: estrutura dos vínculos do trabalhador com a organização, a carreira e o sindicato. Tese de Doutorado-Instituto de Psicologia da Universidade de Brasília, Brasília, 1994.

BASTOS, A.V.B. \& BORGES-ANDRADE, J.E. Padrões de comprometimento com o trabalho em diferentes contextos organizacionais. In: ENANPAD 99, Foz do Iguaçu, Anais do 23o Encontro da ANPAD - CD-ROM, 1999.

BASTOS, A.V.B. \& COSTA, F.M. Múltiplos comprometimentos no trabalho articulando diferentes estratégias de pesquisa. In: ENANPAD 2000, Florianópolis, Anais do 240 Encontro da ANPAD - CD-ROM, 2000 
BASTOS, A.V.B \& PEREIRA, A.M. Mudanças organizacionais e comprometimento no trabalho. In: ENANPAD 97, Rio de Janeiro, Anais do 21o Encontro da ANPAD - CDROM, 1997.

BASTOS, A.V.B; BRANDÃO, M.G.A. \& PINHO,A.P.M. Comprometimento organizacional: uma análise do conceito expresso por servidores universitários no cotidiano de trabalho. In: ENANPAD 96, Rio de Janeiro, Anais do 20o Encontro da ANPAD - CD-ROM, 1996.

BASTOS, A.V.B.; CORREA, N.C.N. \& LIRA, S.B. Padrões de comprometimento com a profissão e a organização: o impacto de fatores pessoais e da natureza do trabalho. In: ENANPAD 98, Foz do Iguaçu , Anais do 22o Encontro da ANPAD - CD-ROM, 1998.

BECKER, H. S. Notes on the concept of commitment. American Journal of Sociology, v. 66, p. 32-42, 1960.

BORGES, J.E, AFANASIEF, R. S. \& SILVA, M. S. Mensuração de comprometimento organizacional em instituições públicas. In: XIX Reunião Anual de Psicologia 1989. Anais da $19^{\circ}$ reunião Anual de Psicologia, p. 236. Ribeirão Preto, 1989.

BORGES-ANDRADE, J.E. \& PILATI, R. Comprometimento atitudinal e comportamental: relações com suporte e imagem nas organizações. In: ENANPAD 99, Foz do Iguaçu, Anais do 23o Encontro da ANPAD - CD-ROM, 1999.

BUARQUE C. O pensamento em um mundo Terceiro Mundo, 1993. In: BURSZIYN, M. et al, , Para Pensar o Desenvolvimento Sustentável, São Paulo, Brasiliense, 1993.

BURSZIYN, M., MENDES, A., SACHS I., BUARQUE C., DOWBOR L., AGUIAR R.C.,BECHER B. e LEITÃO P., Para Pensar o Desenvolvimento Sustentável, São Paulo, Brasiliense, 1993.

BUCHANAN B. Building Organizational Commitment: The socialization of managers in work organizations. Administrative Science Quarterly, v. 19, p. 533-546, 1974.

CARSON R. Primavera Silenciosa. 2 ed. São Paulo: Edições Melhoramentos, 1969

CHANG Junior, João. \& ALBUQUERQUE L. Galvão. Inovações Tecnológicas w o Comprometimento Organizacional. In: X Seminário Latino-Iberoamericano de Gestión Tecnológica, ALTEC. 2003.

CHARLOTE B., SILVA V.A. Relação com a natureza e educação ambiental. In: SATO M. \& CARVALHO I. (orgs.) Educação ambiental. Porto Alegre: Artmed, 2008. Disponível em: https://books.google.com.br. Acesso em: novembro.2015

Consciência Política. WEBSITE. 2011. Disponível em:

www.portalconscienciapolitica.com.br. Acesso em:18 jan.2016.

COOPER, D. R.; SCHINDLER, P. S. Métodos de Pesquisa em Administração. Tradução de Luciana de Oliveira da Rocha. 7.ed. Porto Alegre: Bookman, 2003.

CORAZZA, R. I. Abordagem contratual para o controle ambiental: instrumento de estratégia competitiva ou ingerência privada nas políticas ambientais? In: ENCONTRO NACIONAL DE PÓS-GRADUAÇÃO EM ADMINISTRAÇÃO, 24., 2001, Campinas. Anais. Campinas: Anpad, 2001.

CORAZZA, R. I. Gestão ambiental e mudanças na estrutura organizacional, RAE-eletrônica, v. 2, n. 2, jul-dez/2003 - http://www.rae.com.br - acesso maio/2014. 
COSTA F.M. Comprometimento Organizacional: Bases para uma abordagem processual, Psicologia. Teoria e Pesquisa, n.3, v.30, p. 329-337, 2014.

CURO R. G.; BELDERRAIN C. \& CASTELLINI M. A. Mapa Cognitivo do método SODA aplicado ao problema da produção científica no ensino superior. In: EPIO, 2012, Buenos Aires, XXV.ENDIO - www.epio.org.ar - Acesso em: março/2015.

DIAS, R., Gestão Ambiental, 2.ed. São Paulo: Atlas, 2011.

DIAS V.L.N.; MARTINS J.D.B.; PRESTES L.D.; SILVA R. Educação Ambiental, 2012 disponível em: http://www.historia.art.br/arquivos . Acesso em: dezembro/2015

EDEN, C; SIMS, D. On the nature of problems in consulting practice. Omega, UK, v.7, n.2, p. 119-127, 1979.

EDEN, C; SIMS, D. Subjectivity in problem identification. Interfaces. USA, V. 11, n. 1, p. 68-74, 1981.

GADOTTI, Moacir. Autonomia da escola: princípios e preposições. São Paulo: Cortez, 1997.

GADOTTI, Moacir. Ecopedagogia, Pedagogia da Terra, Pedagogia da Sustentabilidade, Educação ambiental e Educação para a Cidadania Planetária, 2009. Disponível em: http://www.paulofreire.org/Crpf/Crpf.Acervo000137. Acesso em: janeiro/2014.

GAUDIANO E.G. Interdisciplinaridade e educação ambiental: explorando novos territórios epistêmicos. In: SATO M. \& CARVALHO I. (orgs.) Educação ambiental. Porto Alegre: Artmed, 2008. Disponível em: https://books.google.com.br. Acesso em: 3 nov.2015.

GRALTEC Treinamentos. WEBSITE. 2016. Disponível em: www.graltec.com. Acesso em: 1 ago.2016.

GRUN M. O conceito de holismo em ética ambiental e educação ambiental. In: SATO M. \& CARVALHO I. (orgs.) Educação ambiental. Porto Alegre: Artmed, 2008. Disponível em: https://books.google.com.br. Acesso em: novembro.2015

FARIA, J. H. \& SCHMITT, E. C. Indivíduo, vínculo e subjetividade: o controle social a serviço das organizações. In: FARIA, J. H. (Org.). Análise crítica das teorias e práticas organizacionais. São Paulo: Atlas, 2007.

FASOLO, R. Identificação com a organização e qualidade de vida: "antigos" e "novos" funcionários do "banco moeda" da região das missões. Dissertação (Mestrado em Administração) - Universidade Federal do Rio Grande do Sul, Porto Alegre, 2009.

HAIR, Jr., J. F.; BABIN, B.; MONEY, A. H.; SAMOUEL, P. Fundamentos de Métodos de Pesquisa em Administração. Tradução de Lene Belon Ribeiro. Porto Alegre: Bookman, 2005.

HARMAN, W.; HORMANN, J. O trabalho criativo: o papel construtivo dos negócios numa sociedade em transformação. São Paulo: Cultrix, 1990.

HORN J.; CERUTTI B.B. Comprometimento organizacional: Um estudo de caso com a equipe de vendas de uma distribuidora de bebidas do vale do Taquari/RJ, Revista Destaques Acadêmicos, n.1, v.5, 2013

HREBINIAK, H. P. \& ALLUTO, J. A. Personal and role-related factores in the development of organizational commitment. Administrative Science Quarterly, v. 17, p. 555-573, 1972. 
Instituto Ethos de Empresas e Responsabilidade Social. WEBSITE. Disponível em: www3ethos.org.br. Acesso em: 10 out.2015.

JACOBI, Pedro. Educar para a sustentabilidade: complexidade, reflexividade, desafios. Revista Educação e Pesquisa - v. 31/2 - maio-agosto, 2005.

JARDIM, S. B. Mapas Cognitivos: um caminho para construir estratégias. 2 Revista Academica da Face Pucrs, Porto Alegre, v. 12, p. 89-115, 2001.

KRAMER G.G. \& FARIA J.H. Vínculos Organizacionais. Revista de Administração Pública - RAP, v. 41, p. 83-104, 2007.

LAYRARGUES, P.P. Identidades da Educação Ambiental Brasileira. Brasília: Edições MMC, 2004.

MALHOTRA, Naresh K. Pesquisa de Marketing: uma orientação aplicada. Tradução de Laura Bocco. Porto Alegre: Bookman, 2006.

MASLOW, A.H. Maslow no Gerenciamento. Rio de Janeiro: Qualitymark, 2001.

MOTTA, Márcio J. A educação ambiental nas empresas e o Sistema de Gestão Ambiental. Disponível em: https://techoje.com.br. Acesso em: 17 dez.2016.

MATHIEU, J. E., \& HAMEL. K. A causal model of antecedents of organizational commitment among professionals and nonprofessionals. Journal of Vocational Psychology, v. 34, p. 299-317, 1989.

MATHIEU, John E. \& ZAJAC, Dennis M. A Review and Meta-Analysis of the Antecedents, correlates, and Consequences of Organizational Commitment, Journal of Vocational Psychology. v. 108, p. 171-194, 1990.

McGEE, G. W. \& FORD, R. C. Two (or more?) dimensions of organizational commitment: reexamination of the affective and continuance commitment scales. Journal of Applied Psychology. v. 72(4), p. 638-641, 1987.

MENEZES, I. G. \& BASTOS A.V.B. - Comprometimento organizacional atitudinal: um estudo empírico sobre a dimensionalidade do construto. Estudos de Psicologia I - Campinas I 28(4) p. 463-474, out./dez. 2011.

MEDEIROS, Carlos Alberto Freire. Comprometimento organizacional: um estudo de suas relações com características organizacionais e desempenho nas empresas brasileiras. Tese de Doutorado-Faculdade de Economia, Administração e Contabilidade da Universidade de São Paulo, São Paulo, 2003.

MEYER, J.P. \& ALLEN, N.J. Testing "side-bet theory" of organizational commitment: some methodological considerations. Journal of Applied Psychology, 69(3), 373-378, 1984.

MEYER, J. P. \& ALLEN, N. J. A three-component conceptualization of organizational commitment. Human Resource Management Review. v.1, p. 61-89, 1991.

MEYER, J. P. \& ALLEN, N. J. Commitment in the workplace: theory, research and application, Thousand Oaks: Sage Publications. 1997.

MORAES, L. F. R.; MARQUES, A. L.; KILIMNINK, Z. M.; PEREIRA, L. Z. \& SANTOS, C. M.Q. Comprometimento organizacional: um estudo de caso comparativo em universidades federais mineiras. In: ENANPAD 97, Rio de Janeiro, Anais do $21^{\circ}$ Encontro da ANPAD CD-ROM, 1997. 
MORAES, L. F. R.; MARQUES, A. L. \& CORREIA, L. F. Comprometimento organizacional: uma contribuição ao constructo. In: ENANPAD 98, Rio de Janeiro, Anais do $22^{\circ}$ Encontro da ANPAD - CD-ROM, 1998.

MORITA, T. Mapas Cognitivos SODA ampliados: Prescrição de um método para articular atitudes, comportamentos e sequencias cognitivas a mapas SODA. Tese de Doutorado-Escola de Administração de Empresas de São Paulo - fundação Getúlio Vargas, São Paulo, 2013.

MOWDAY Richard T.; STEERS, R. M. \& PORTER, L. W. The Measurement of Organizational Commitment. Journal of Vocational Behavior, v. 14, p. 224-247, 1979.

MOWDAY, Richard T.; PORTER, L. W. \& STEERS, R. M. Employee_Organization linkages - the psychology of commitment, absenteeism and turnover. New York. Academic Press. 1982.

NEAL, P. Teaching sustainable development. Environmental Education, 50:8-9. 1995

NICOLELLA, G; MARQUES J.F.; SKORUPA, L.A. Sistema de Gestão Ambiental: aspectos teóricos e análise de um conjunto de empresas da região de Campinas, SP. Documentos 39 ISSN 1516-4691- EMBRAPA, 2004.

O`REILLY III, C. \& CHATMAN, J. Organizational commitment and psychological attachment: the effects of compliance, identification, and internalization on proposal behavior, Journal of Applied Psychological, v.71(3), p. 492-00,1986.

O`REILLY III, C. A. \& PFEFFER, J. Talentos ocultos: Como as melhores empresas obtém resultados extraordinários com pessoas comuns. Rio de Janeiro: Campus, 2001.

PAIVA K.C.M., DUTRA M.R.S. \& LUZ T.R. Comprometimento organizacional de trabalhadores de Call Center, Revista de Administração, n.3, v.50, p.310-324, 2015.

PASSOS L.A. \& SATO M. De asas de jacarés e rabos de borboletas à construção fenomenológica de uma canoa. In: SATO M. \& CARVALHO I. (orgs.) Educação ambiental. Porto Alegre: Artmed, 2008. Disponível em: https://books.google.com.br. Acesso em: 3 nov.2015.

$\mathrm{Pa}$ - Portal Administração. WEBSITE. 2013-2015. Disponível em: www.portaladministração.com. Acesso em: 1 ago.2016.

PFEFFER, J. \& VEIGA, J. F. Putting people first for organizational succes. Academy of Management Executive, v. 13(2), p. 37-48, 1999.

PORTER L.W., STEERS R.M. Organizational, work, and personal factors in employee turnover and absenteeism. Psychological Bulletin, v. 80, p. 161-176, 1973

PORTER L.W., STEERS R.M, MOWDAY R.T. \& BOULIAN P.V. Organizational commitment, job satisfaction, and turnover among psychiatric technicians, Journal of Applied Psychology, v.59, p. 603-609, 1974

PORTER L.W., CRAMPON W.J. \& SMITH F.J. Organizational commitment and managerial turnover: A longitudinal study, Organizational Behavior and Human Performance, v.15, p. 87-98, 1976.

QUINTAS, J.S. \& GUALDA, M.J. A formação do educador para atuar no processo de gestão ambiental. Brasília: Ibama. 1995. 
REIGOTA, Marcos, O que é educação ambiental, São Paulo: Brasiliense, 2001.

RICCO, Maria F. F. Comprometimento organizacional em condições adversas: o caso dos pesquisadores do Centro Técnico Aeroespacial. Dissertação de Mestrado-PPGA/FEA/USP, 1998.

SAUVÉ L. Uma cartografia das correntes em educação ambiental. In: SATO M. \& CARVALHO I. (orgs.) Educação ambiental. Porto Alegre: Artmed, 2008. Disponível em: https://books.google.com.br. Acesso em: 3 nov.2015.

SATO M. \& CARVALHO I. Educação Ambiental, Porto Alegre: Artmed, 2008. Disponível em: https://books.google.com.br. Acesso em: 3 nov.2015.

SElltiZ, C.; WrightSMAN, L. S.; COOK, S. W. Métodos de Pesquisa nas Relações Sociais. Tradução de Maria Marta H. D’Oliveira \& Mirian Marinotti Del Rey. 2.ed. São Paulo: EPU, 1987.

SILVA, M. C. C. Avaliação do comprometimento dos servidores de uma Instituição Pública de Pesquisa: O caso dos Pesquisadores do IPEN. Dissertação de MestradoPPGA/FEA/USP, 2007.

SILVEIRA, V.N.S.\& MIRANDA D.L.A. Estratégia de Gestão de Pessoas e as Abordagens Normativa: Uma Análise Conceitual no Contexto da Gestão Estratégia de Pessoas. In: EnANPAD - XXXV Encontro da ANPAD, 2011.

TAMAYO, A. Valores Organizacionais e Comprometimento Afetivo, Revista de Administração Mackenzie. a.6, n.3, p.192-213, 2005.

TENÓRIO, F.G. Responsabilidade social empresarial - Teoria e prática, 2.ed. Rio de Janeiro: FGV, 2006.

WIENER Yoash. Commitment in Organizations: A Normative View. Academy of Management Review, v.7, p. 418-428, 1982. 


\section{APÊNDICES}

APÊNDICE I - Coleta de dados primários

Questionário elaborado para discussão inicial relativa ao exame de possíveis incertezas, complexidades e conflitos, em relação ao elemento comprometimento, quando da adoção de um SGA, cuja composição partiu dos seguintes entendimentos:

Comprometimento organizacional visto como o nível do vínculo psicológico de um indivíduo com a organização, onde esse vínculo tem implicação na resolução do empregado em permanecer na empresa e cuja descrição da natureza do estado psicológico foi tida como afetiva: o comprometimento visto como o resultado de um vinculo afetivo em relação à organização; instrumental: o comprometimento como resultante de um vínculo que decorre dos custos associados em deixar a organização; e normativa: o comprometimento como o reflexo do sentimento de obrigação em permanecer na organização.

Sistema de Gestão Ambiental - SGA definido como procedimentos que irão ajudar a organização a entender, controlar e diminuir os impactos ambientais de suas atividades, produtos eou serviços e que tem como suporte o cumprimento da legislação ambiental vigente e a melhoria contínua com análise crítica.

1) A quantidade de materiais, insumos, equipamentos necessários para o desenvolvimento de suas tarefas foi uma preocupação que se deu juntamente com o inicio de sua vida profissional, ou deu-se com o passar dos tempos? Essa preocupação se alterou ao longo de sua carreira? Por quê? e Como?

2) Quando o Sr. (a) depara com uma quantidade de lixo (descartes) em seu caminho, por exemplo na vida para o trabalho, ou em outro deslocamento para quaisquer lugares seu primeiro sentimento é:

a) Ignorar;

b) Ignorar naquele momento, no entanto, após algumas horas ou até mesmo dias aquela visão lhe incomoda;

c) Incomodar-se imediatamente ao vê-lo.

3) Como esse sentimento se ligaria quando na iniciativa da adoção de uma gestão ambiental em seu ambiente de trabalho?

4) Ao receber informações sobre os riscos que o planeta corre com a exploração demasiada dos recursos naturais, vem ao Sr. (a) um sentimento de preocupação ou tais comentários não lhe afetam diretamente. Por quê? 
5) Informações sobre esses possíveis riscos, se liga de alguma forma, a maneira como o Sr. (a) vê como estão sendo desenvolvidas as atividades em seu ambiente de trabalho? Como?

6) Em meio a satisfação do reconhecimento de seu trabalho bem sucedida o Sr. (a) depara-se com a preocupação de seu trabalho ter também contribuído para amenizar os problemas ambientais tão destacados nos últimos tempos?

7) Qual a sua opinião em relação à crise atual enfrentada por alguns países desenvolvidos cujas riquezas naturais estão se extinguindo rapidamente? O Sr. (a) acredita que esse tipo de situação possa ocorrer também em organizações bem sucedidas, como a Instituição em que trabalha? Por quê? Como?

8) Se consultado sobre pequenas iniciativas, que vem sendo tomadas por algumas O.N.G.s e até mesmo por grandes redes de supermercado, como o reaproveito do óleo de cozinha, ou do papel, de latinhas de alumino entre outras, qual seria sua opinião a respeito?

9) No desenvolvimento de suas atividades em que constância o Sr. (a) verifica sua preocupação em relação as contribuições que tal feito irá proporcionar ao meio ambiente?

10) Quantas vezes em sua vida o Sr. (a) se deparou com preocupações concernentes a sobrevivência da raça humana?

11) Em sentido geral, o imediatismo lhe atrai?

12) Hipoteticamente, em um ambiente familiar o assuntos discutido é o futuro do planeta, colocando-se como participante dessa discussão o que lhe atrairia/preocuparia nesse assunto? Esse assunto levaria o Sr. (a) a pensar no tipo de atividade da Instituição em que trabalha e como ela vem sendo desenvolvida? 


\section{APÊNDICE II - Mapa cognitivo final sem interação grupal}

\section{Ausência de conhecimento suficiente por parte dos} servidores que compõem as áreas de apoio e

infraestrutura da Instituição em relação a importância de uma Gestão Ambiental.. "Transmitir conhecimento."

\section{$\checkmark$ \\ 7. Falta de incentivos aos servidores com relação a adoção de uma Gestão Ambiental. ... Incentivar}

5. Falta criar ações para adotar um

SGA .... "Criar ações."

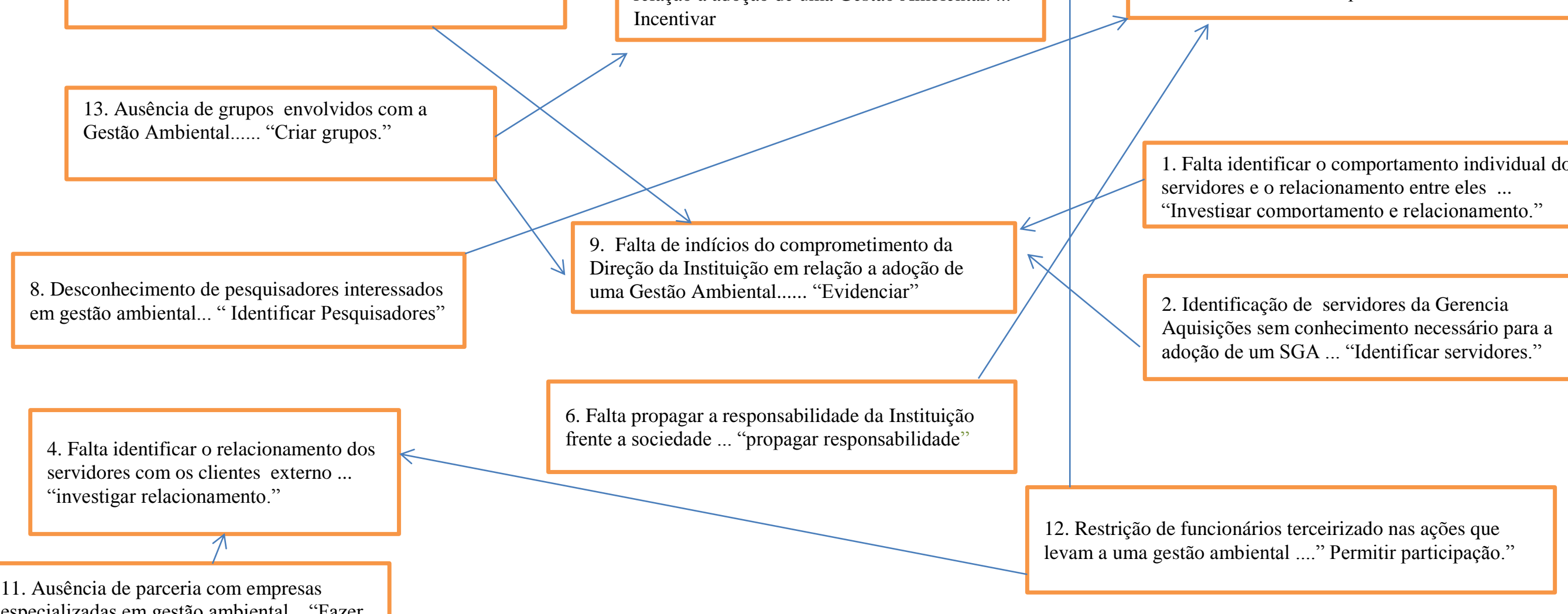

11. Ausência de parceria com empresas especializadas em gestão ambiental... "Fazer parcerias".

Fonte: adaptado do modelo de Curo et al, 2012 
APÊNDICE III - Mapa cognitivo final com interação grupal

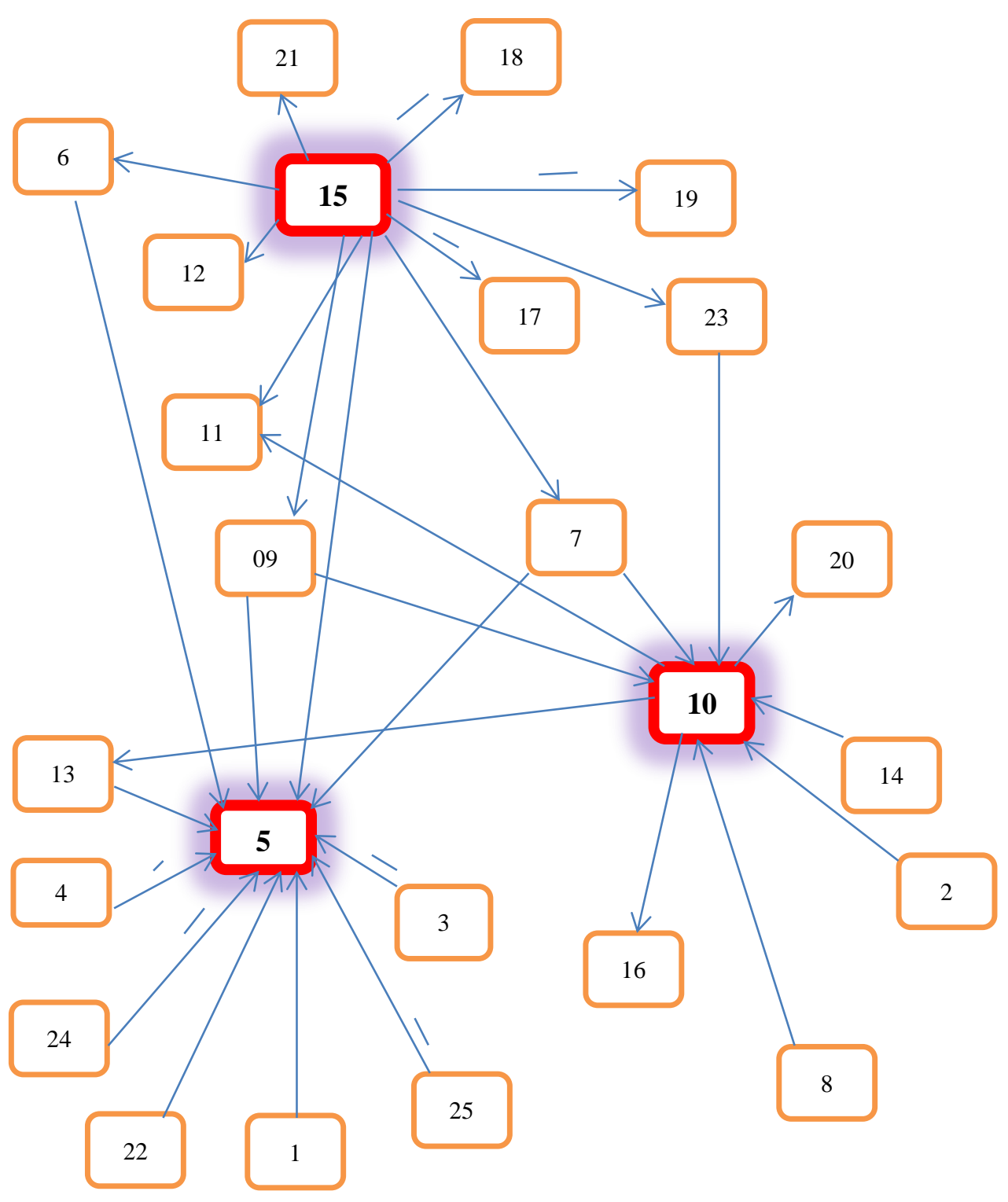

\section{Legenda:}

\begin{tabular}{|c|c|}
\hline 1 & $\begin{array}{l}\text { Falta identificar o nível de incorporação dos valores da Instituição aos servidores ... } \\
\text { adotar ações }\end{array}$ \\
\hline 2 & $\begin{array}{l}\text { Falta identificar ações que mantenham os valores }{ }^{1} \text { da Instituição incorporados de forma } \\
\text { continua às atividades dos servidores ...buscar a difusão }\end{array}$ \\
\hline 3 & $\begin{array}{l}\text { Ausência de divulgação da importância de um Sistema de Gestão Ambiental ... promover } \\
\text { a divulgação }\end{array}$ \\
\hline 4 & $\begin{array}{l}\text { Falta disseminar as possibilidades que as politicas da Instituição já possuem em relação } \\
\text { a adoção de uma Gestão Ambiental ... Propagar os produtos e serviços" }\end{array}$ \\
\hline 5 & $\begin{array}{l}\text { Falta identificar elementos que favoreçam a implementação de um Sistema de } \\
\text { Gestão Ambiental bem sucedido ... identificar elementos }\end{array}$ \\
\hline 6 & $\begin{array}{l}\text { Falta propagar o compromisso dos Gestores da Instituição em relação a adoção de um } \\
\text { Sistema de Gestão Ambiental ... divulgar o compromisso }\end{array}$ \\
\hline 7 & $\begin{array}{l}\text { Falta promover esclarecimentos a respeito da necessária adoção de um Sistema de } \\
\text { Gestão Ambiental na Instituição ...Promover esclarecimento }\end{array}$ \\
\hline 8 & $\begin{array}{l}\text { Ausência de ações que permitam a participação de funcionários terceirizados na } \\
\text { implementação de um Sistema de Gestão Ambiental ... Adotar iniciativas }\end{array}$ \\
\hline 9 & $\begin{array}{l}\text { Falta de conhecimento especifico para a implementação de Sistema de Gestão Ambiental } \\
\text {... Contratar Serviços }\end{array}$ \\
\hline 10 & $\begin{array}{l}\text { Indisponibilidade de estrutura adequada e de recursos humano e financeiro para a } \\
\text { implementação de um Sistema de Gestão Ambiental ... Angariar recursos }\end{array}$ \\
\hline 11 & Falta conhecer empresas cuja Gestão Ambiental esteja consolidada ... Promover visitação \\
\hline 12 & $\begin{array}{l}\text { Ausência de parceria com empresas que possuem Sistema de Gestão Ambiental bem } \\
\text { sucedido ... Propor parcerias }\end{array}$ \\
\hline 13 & $\begin{array}{l}\text { Falta difundir em linguagem apropriada aos servidores da área meio e funcionários } \\
\text { terceirizados as pesquisas desenvolvidas na Instituição ... Promover Propagação }\end{array}$ \\
\hline 14 & $\begin{array}{l}\text { Falta difundir aos servidores da área meio e funcionários terceirizados os produtos e } \\
\text { serviços disponibilizados à sociedade pela Instituição ... Propagar a propagação }\end{array}$ \\
\hline 15 & $\begin{array}{l}\text { Falta conscientização da importância em se trabalhar sob uma Gestão Ambiental ... } \\
\text { Maximizar açôes }\end{array}$ \\
\hline 16 & $\begin{array}{l}\text { Falta divulgar no âmbito da Instituição como são desenvolvidas as atividades de pesquisa } \\
\text { em relação meio ambiente ... Propagar a divulgação }\end{array}$ \\
\hline 17 & $\begin{array}{l}\text { Falta divulgar no âmbito da Instituição como são desenvolvidas as atividades da área } \\
\text { meio em relação ao meio ambiente ... Propagar a divulgação }\end{array}$ \\
\hline 18 & $\begin{array}{l}\text { Resistencia em relação a participação de terceirizados nas ações que levam a adoção de } \\
\text { uma Gestão Ambiental ... Propagar permissivo }\end{array}$ \\
\hline 19 & $\begin{array}{l}\text { Falta tornar devidamente clara a obrigatoriedade da alta administração em relação ao } \\
\text { direcionamento das ações essenciais da Instituição no campo social ... Propagar a } \\
\text { obrigatoriedade }\end{array}$ \\
\hline 20 & $\begin{array}{l}\text { Falta propagar o relacionamento da Instituição com os clientes externos ... Propagar o } \\
\text { relacionamento }\end{array}$ \\
\hline 21 & $\begin{array}{l}\text { Falta conhecer e responder as expectativas da sociedade concernentes a maneira em que } \\
\text { são desenvolvidas as atividades da Instituição ... Investigar as expectativas }\end{array}$ \\
\hline 22 & $\begin{array}{l}\text { Falta identificar se realmente os valores da Instituição são aceitos pela maioria de seus } \\
\text { servidores ... Investigar a aceitação }\end{array}$ \\
\hline 23 & $\begin{array}{l}\text { Ausência de legislação concernente às aquisições governamentais } \\
\text {...Participação em eventos }\end{array}$ \\
\hline 24 & $\begin{array}{l}\text { Falta identificar os procedimentos da Instituição quando da percepção de indiferença dos } \\
\text { servidores em relação as mudanças ... Divulgar Mecanismos }\end{array}$ \\
\hline 25 & $\begin{array}{l}\text { Falta identificar o comportamento dos servidores em relação a adoção de um Sistema de } \\
\text { Gestão Ambiental ... Pesquisar mecanismos }\end{array}$ \\
\hline
\end{tabular}


APÊNDICE IV - Modelo de mensuração do comprometimento em relação a adoção de um SGA, a ser validado.

\section{Fator 1 (comprometimento AFETIVO)}

1) Eu seria muito feliz em saber que a Instituição em que trabalho preocupa-se com a questão ambiental.

2) Eu realmente sinto como se os problemas relacionados a questão ambiental inerentes a Instituição em que trabalho, fossem meus.

3) Eu não sinto um forte sentimento de "pertencer" a essa Instituição, quando da tratativa por ela de assuntos relacionados a questão ambiental.

4) Eu não me sinto "ligado emocionalmente" com a questão ambiental trabalhada na Instituição.

5) Eu não me vejo como um membro dessa Instituição no que concerne as atividades voltadas para a questão ambiental por ela desenvolvida.

6) A maneira como é tratada a questão ambiental na Instituição tem um grande significado pessoal para mim.

\section{Fator 2 (comprometimento NORMATIVO)}

1) Eu não sinto nenhuma obrigação em contribuir com as ações ligadas as questões ambientais trabalhadas na Instituição.

2) Mesmo que fosse vantajoso para mim, eu não sinto que seria correto abandonar as questões ambientais tratadas na Instituição.

3) $\mathrm{Eu}$ me sentiria culpado se eu começasse a ignorar as questões ambientais trabalhadas na Instituição.

4) As questões ambientais trabalhadas na Instituição merecem minha dedicação e lealdade.

5) Eu não abandonaria as questões ambientais agora porque tenho um sentimento de obrigação para com as atividades assumidas pela Instituição concernente a elas.

6) Eu devo muito de minha conscientização ambiental a participação nas atividades concernente a adoção de um sistema de gestão ambiental pela Instituição. 


\section{ANEXOS}

\section{ANEXO - I - Processo - Strategic Options Development and Analysis - $\underline{\text { SODA }}$}

Os principais métodos de análise de dados qualitativos, segundo Collis \& Hussey, 2005 estão divididos em dois blocos, a saber: Métodos quantitativos e Métodos não-quantitativos.

Entre os Métodos não-quantitativos está o mapeamento cognitivo, o qual como colocado por esses autores é um método de análise que pode ser usado para estruturar, analisar e entender o sentido de narrações escritas ou verbais de problemas.

O mapeamento cognitivo baseia-se na teoria de Kelley (1955) sobre $\operatorname{construtos}^{35}$ pessoais o qual sugere que: “entendemos o mundo para prever como, se tudo permanecer igual, ele será no futuro, e para decidir como poderíamos agir ou intervir para alcançar o que preferimos neste mundo - uma visão de prever e controlar da resolução de problemas." (Ackermann et al., 1990 p.1, apud Collis \& Hussey, 2005, p. 249).

Entre os mapas cognitivos mais conhecidos, segundo Curo et al, 2012 está o Strategic Options Development and Analysis - SODA. Este método de estruturação de problemas, conforme colocado por essas autoras, considera os membros relevantes de uma equipe para a situação problemática e conceitualiza os diferentes pontos de vista do problema, construindo mapas cognitivos individuais e é, segunda elas, um método de identificação de problemas que utiliza mapeamento cognitivo como modelagem para obter e registrar visões individuais de uma situação problemática.

Referente entendimento corrobora-se com o apontamento de Georgiou e Stevaux, 2008 quando colocam que os Métodos de Estruturação de Problemas constroem um mapa de situações problemáticas que auxiliam na identificação dos problemas individuais e suas inter-relações, dizem eles: ... se existe um sistema de problemas é fortemente recomendável encontrar uma solução sistêmica. (Georgiou e Stevaux, 2008, apud Curo et al, 2012, p. )

Regras para o desenvolvimento de um mapa cognitivo, segundo Curo et al, 2012.

\footnotetext{
${ }^{35}$ Entendido como "pensamentos e ideias de pessoas, a respeito de um problema ou tópico, apresentando-os na forma gráfica e interligados de maneira a dar sentido à evolução dos mesmos, de acordo com a orientação dos arcos de interligação.” (Morita, 2013, p.38)
} 
$1^{\circ}$ passo: construção de mapa cognitivo individual:

$\checkmark$ Os constructos desse mapa cognitivo são conectados por setas direcionadas com outros constructos dando um sentindo de causalidade, refletindo diretamente a maneira como o individuo expressa uma ideia sobre a situação problemática. Assim cria-se uma rede de ideias vinculadas por meio de setas que indicam como uma ideia pode conduzir a outra ou ter implicações sobre ela. Este processo, segundo as autoras, Curo et al, considera-se como meio-fins.

$\checkmark$ A criação do mapa individual é realizada por meio das perguntas formuladas pelo facilitador ao cliente, no caso do presente estudo pelo entrevistador aos quinze entrevistados. Por meio de dessas perguntas obtém-se outros constructos que dão corpo ao mapa, identificando as setas e as relações entre os constructos.

$\checkmark$ As perguntas são seguidas de:

$1^{\circ}$ Por quê? Para procurar explorar as razões de determinada afirmação;

$2^{\circ}$ Como? Para procurar explorar as formas que o cliente discerne como possíveis para viabilizar alguma ação.

$3^{\text {o }}$ Como isto se liga (ao assunto investigado)? Para procurar identificar explicações e consequências de determinada afirmação.

$4^{\circ}$ Em vez de (...tal saída; ... sugestão; ... implicância; entre outras)? Para explorar o conteúdo daquilo que foi dito pelo investigado.

As setas podem ter signos negativos ou simplesmente não ser sinalizadas.

a. Setas signos negativos vinculam ideia do primeiro polo de constructos com a ideia do segundo polo de construto

b. Setas signos não sinalizadas quando ambos constructos indicam que seus polos serão lidos em ordem.

$2^{\circ}$ passo Construção do mapa estratégico

$\checkmark$ Os mapas SODA propõem que o facilitador (investigador para esse estudo em específico) fusione os mapas cognitivos individuais formando um para coletivo ou estratégico, que consiste na agrupação dos mapas individuais, unindo conceitos comuns aos mapas e construindo ligações entre os conceitos que não são equivalentes, mas tem a reação de influência.

$\checkmark$ Para unir uma o mais conceitos similares, é importante analisar qual deles deve ser conservado no mapa estratégico. O construto que se perde também mencionado como "rich" é o que apresenta menor grau de importância. 
$\checkmark$ As setas nesse momento deverão ser utilizadas pelo facilitador de forma a empregar sua capacidade de juízo para manter as relações hierárquicas dentro do mapa final fusionado.

$3^{\circ}$ Passo Construção do Mapa estratégico com interação grupal.

$\checkmark$ Para a construção desse mapa final se faz necessária a análise bem detalhada do mapa estratégico para que dessa forma possa garantir a representação balanceada dos membros chaves da equipe. Após essa analise são realizadas as reuniões com a equipe para finalização do mapa. 


\section{ANEXO - II - Strategic Options Development and Analysis - SODA - utilizada no presente estudo.}

Considerando a colocação de Eden \& Sims (1981) de que as situações complexas precisam primeiramente ser entendidas, para posteriormente definir-se claramente o problema a ser resolvido, visto que o problema torna-se mais complicado na medida em que os pesquisador necessita empregar muitas perspectivas e que a situação política que fundamenta o problema, e forma a base das atividades do grupo é de importância crítica para as atividades do pesquisador.

O Mapa Cognitivo SODA, tem o rigor e formalismo derivado da teoria de construtos pessoais de Kelly (1955) cujo entendimento é como os indivíduos buscam significados para o seu mundo na intenção de administra-lo e controla-lo.

Mapa Cognitivo SODA é o desenho obtido como resultado da tarefa de mapear os pensamentos e ideias de pessoas, a respeito de um problema ou tópico, apresentando-os na forma gráfica e interligados de amaneira a dar sentido à evolução dos mesmos, de acordo com a orientação dos arcos de interligação. (Morita, 2013, p. 38).

Elementos

\section{a) construtos}

Construtos são pensamentos e ideias, eventos e palavras que expressem ação. Na metodologia SODA adota-se o corolário da dicotomia que segundo Kelly apud Morita, 2013, resulta do entendimento de que as pessoas buscam significados das situações por meio de semelhanças e diferenças.

Segundo Morita (2013) a dicotomia é materializada num construto pela inserção de uma segunda frase no corpo do construto, o que faz com que cada construto seja constituído por dois polos contrastantes. O polo principal contém a declaração extraída, e o polo secundário o contraponto, ou alternativa psicológica, conforme o entendimento do analista.

\section{a.1) Tipos de construtos:}

$\checkmark$ Tail: construtos designados como causa primária, ou fato básico existente, que se torna um argumento-origem no grafo, os arcos que conectam este construto são do tipo que partem dele;

$\checkmark$ Head: construtos no qual todo arco que o conecta tem o sentido de entrada. Esse construto por ter várias interpretações possíveis, dependendo de seu conteúdo, suas 
relações com outros construtos, bem como da trajetória da sequência de arcos para atingi-lo. Esse construto reflete os objetivos, resultados, saídas ou consequências

$\checkmark$ Intermediário: todos os demais construtos que tenham conectado a si tanto arcos de entrada quanto arcos de saída (Morita, 2013, p. 40), nos construtos intermediários os que localizam em posição imediatamente antecedente aos construtos heads, são os Strategic Options, por ser construto que canaliza o fluxo de construtos para os objetivos e metas do mapa.

b) $\operatorname{Arcos}$

Setas que indicam o sentido da evolução de ideias, pensamentos, eventos e ação. Os arcos possuem sinais:

Positivo = significa que o polo principal do construto tail, que origina esse arco, influencia o polo principal do construto head, destinatário do arco. Em consequência, e concomitantemente, o polo secundário do construto tail influencia o polo secundário do construto head. (Morita, 2013)

Negativo = significa que o argumento, ou o polo principal do construto tail leva ao contraargumento, ou polo secundário do construto head. Do mesmo modo o polo secundário do construto tail influencia o polo principal do construto head.

\section{c) Domínio de um construto}

A analise de Dominants segundo Morita (2013) é a forma para se descobrir o significado e a influencia que um construto exerce, ou sofre no âmbito do mapa SODA. O domínio de um construto pode ser caracterizado por meio de Explosions e Implosions, assim definidas: Explosions de um construto é a quantidade de arcos que partem do mesmo e Implosions de um construto é a quantidade de arcos incidentes no mesmo.

Implosions - São identificados pelo cálculo de seu grau (IG) para cada construto. O IG identifica-se como o número de construtos que recebe, ou seja, implosion é o construto com maior IG. Em SODA, estes implosions indicam efeito maior por ser afetado por múltiplos outros construtos e por múltiplas áreas do mapa.

Explosions - São identificados pelo cálculo de seu grau (EG) para cada construto. O EG identifica-se como o número de constructos que parte dele, ou seja, explosion é o construto com maior - EG. Em SODA, estes explosions indicam efeito maior por afetar múltiplos outros construtos e múltiplas áreas do mapa. 
Dominants - São aqueles construtos que tem o maior número de construtos que recebem e distribuem, ou seja, aqueles que a soma de EG e IG é maior. 